
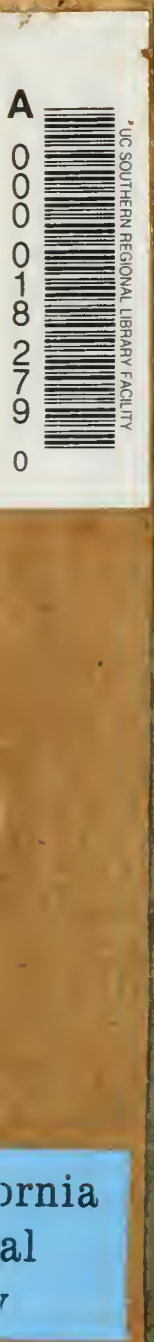

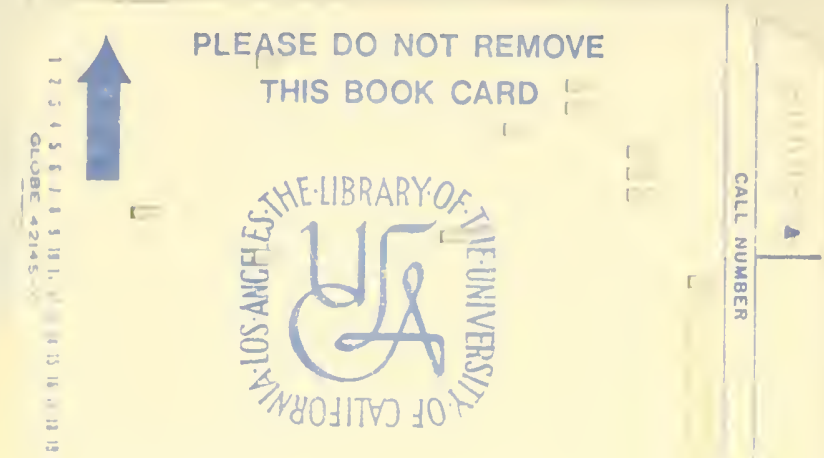

University Research Librafy

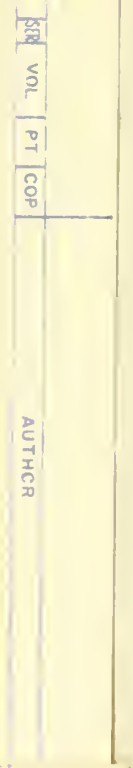


University of California

SOUTHERN REGIONAL LIBRARY FACILITY 405 Hilgard Avenue, Los Angeles, CA 90024-1388

Return this material to the library

from which it was borrowed. 
<smiles>C1CC1</smiles> 

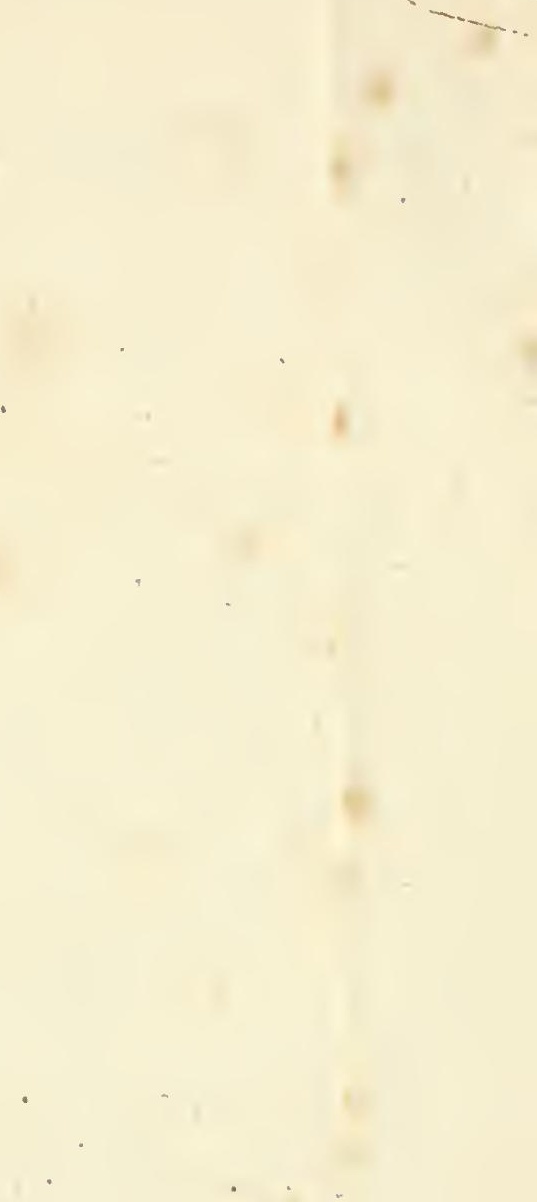


\section{Nixldetil}

oi 山ा:

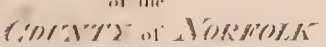

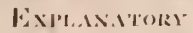

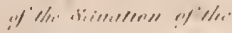

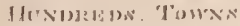

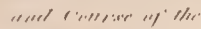

KINRS:

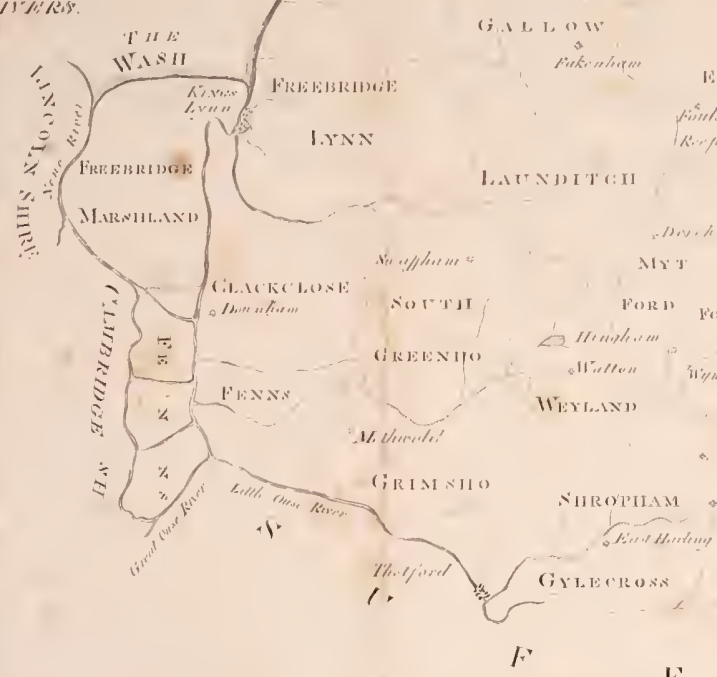

F

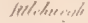

×ั1тा

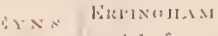
tr.tilutin

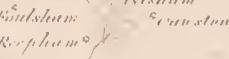

H.

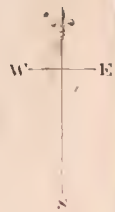

IIINGIAN

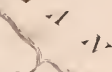




\section{GENERAL VIEW}

OF THE

$A G \mathbb{R} I C U \mathbb{L} U \mathbb{R} \mathbb{E}$

OF THE

\section{County of 报orfolk;}

WITH OBSERVATIONS

For the Means of its Improvement.

Drawn up, for the Confideration of the

\section{BOARD OF AGRICULTURE}

\section{Gnd Internal Improvement,}

BY

$\mathcal{N} A \mathbb{T} \mathbb{H} A \mathcal{N} \mathbb{E} \mathbb{L} E \mathbb{K} \mathbb{N}$

OF FULHAM, MIDDLESEX.

With additional Remarks from feveral refpectable Gentlemen and Farmers.

"Ye generous Britons, venerate the Plough."

THOMSON.

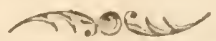

printco at the foorfoth lloreon,

BI CROUSE, STEVENSON, AND MATCHETT,

MARKET-PIACE, NORW I C H,

FOR GEORGE NICOL, PALL-MAIL, LONDON.

$$
1796 .
$$





\section{$A \mathbb{D} \mathbb{E} \mathbb{R} \mathbb{T} \mathbb{S} \mathbb{E} \mathbb{N} \mathbb{N} \mathbb{T}$}

FROM TIIE

\section{Lisoard of Agriculture.}

THE great desire that has been very generally expressed, for having the AGRICULTURAI SURVETS of the KINGDOM re-printed, with the additional communications which have been received since the ORIGIN.AL REPORTS were circulated, has induced the BOARD of AGRICULTURE, to come to a resolution of re-printing such as may appear on the whole fit for publication; and it roill thankfully acknowledge any additional information which may still be communicated: An invitation, of which, it is hoped, many will avail themselves, as there is no circumstance from which any one can derive more real satisfaction, than that of contributing, by every possible means, to promote the improvement of his country.

52. 33. Letters to the Board, may be addressed to $S_{18}$ Jo Ir Sixсслык, Bakr. the President, M!. P'. London.

LomDon, JUNE, I795. 


\section{$\mathbb{P} \mathbb{I} \mathbb{A} \mathbb{N}$}

For $\mathbb{R} e=$ printing the

\section{Agricultural Surveys.}

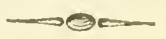

By the President of the Board of Agriculture.

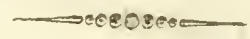

A BOARD eftablifhed for the purpofe of making every effential enquiry into the Agricultural State, and the means of promoting the internal improvement of a porverful Empire, will neceffarily have it in view, to examine the fources of public profperity, in regard to various important particulars. Perhaps the following is the moft natural order for carrying on fuch important inveftigations; namely, to afcertain,

1. The riches to be obtained from the furface of the national territory.

2. The mineral or fubterraneous treafures of which the country is poffeffed.

3. The wcalth to be derived from its freams, rivers, canals, inland narigations, coans, and filheries. And 
1. The means of promoting the improvement of the people, in regard to their health, induftry, and morals, founded on a fatifiical furvey, or a minute and careful enquiry into the actual fate of every parochial diftrict in the kingdom, and the circumftances of its inhabitants.

Under one or other of thefe heads, every point of real importance, that can tend to promotc the general happinefs of a great nation, feems to be included.

Inveftigations of fo cxtenfive and fo complicated a nature, muft require, it is evident, a confiderable fpace of time before they can be completed. Differing indeed in many refpects from each othe:, it is better, perlaps, that they flould be undertaken at different periods, and feparately confidercd. Under that impreffion, the loard of Agriculture has hitherto dirccted its attention to the fir 2 point only, namely, the cultivation of the furface, and the refources to be derived from it.

That the facts effential for fuch an invenigation, might be collected with more celerity and adrantage, a number of inteilisent and refpectable individuals were appointed, to furnilh the Eoard with accounts of the nate of hufbandry, and the means of improving the different difricts of the kingdom. 'The returns tisey leut were printed, and circulated 
by every means the Board of Agriculture could devile, in the difricts to which they refpectively related; and, in confequence of that circulation, a great mafs of additional valuable information has been obtained. For the purpofe of communicating that information to the Public in general, but more efpecially to thofe counties moft interelted therein, the Board has refolved to reprint the Surrey of each County, as foon as it fecmed to be fit for publication; and, among fereral equally advanced, the counties of Norfolk and Lancafter were pitched upon for the commencement of the propoled publication; it being thought moft advifable, to begin with one county on the Eaftern, and another on the Weftern coaf of the ifland. When all thefe Surveys fhall hare been thus re-printed, it will be attended with little difficulty to draw up an abftract of the whole, (which will not probably exceed two or three volumes quarto) to be laid before his Majefty', and both Houles of Parliament; and afterwards, a general Report on the prefent ftate of the country, and the means of its improvement, may be fyftematically arranged, according to the various fubjects connected with agriculture. Thus every individual in the kingdom may have,

1. An account of the hufbandry of his own particular county; or,

2. $\Lambda$ general view of the agricultural ftate of the kingdom at large, according to the counties 


\section{vii}

counties, or diftricts, into which it is divided; or,

3. An arranged fyftem of information on agricultural fubjects, whether accumulated by the Board fince its eftablifhment, or pre=vioufly known.

And thus information refpecting the fate of the kingdom, and agricultural knowledge in general, will be attainable with every polfible advantage.

In re-printing thefe Reports, it was judged neceffary that they thould be drawn up according to one uniform model; and after fully confidering the fubject, the following form was pitched upon, as one that would include in it all the particulars which it was neceffary to notice in an Agricultural Survey. As the other Reports will be re-printed nearly in the fame manner, the reader will thus be enabled to find out at once, where any point is treated of, to which he may wifh to direct his attention. 
Plan of the Re-Printed Reports.

\author{
warkixar
}

Preliminary Oblervations.

Cirap. I. Geographical State and Circumftances。

Sect. 1.-Situation and Extent.

2.-Divifions.

3.-Climate.

4.- Soil and Surface.

5.-Minerals.

6.-Water.

11. Siate of Property.

SECT.1.-Eftates, and their Management. 2.-Tenures.

1I. Buildings.

SEct. 1.-Houfes of Proprietors.

2.-Farm Houfes and Offices; and Re. pairs.

3.-Cottages.

IV. Mode of Occupation.

SEcT.1.-Size of Farms.-Character of the Farmers.

2.-Rent-in Money-in Kind-in

Perfonal Services.

3.-Tythes.

4.-Poor Rates.

5.-Leafes.

6.-Expence and Profit.

V. Implements.

VI. Incloling-Fences-Gates.

VII. Arable Land.

SECT. 1.-Tillage.

2.-Fallowing.

3.-Rotation of Crops. 
CHAP. VII. continued.

SECr. 4.-Crops commonly cultivated; their

Seed, Culture, Producc, \&c.*

5.-Crops not commonly cultivated.

Cinap. VIII. Grafs.

S氵cr. 1.-Natural Meadows and Paltures.

2.-Artificial Graffes.

3.- Hay Harveft.

4.-Feeding.

1X. Gardens and Orchards.

X. Woods and Plantations.

XI. Waftes.

XII. Improvements.

SECT. 1.-Draining.

2.- Paring and Burning.

3.-Manuring.

4.-Weeding.

5. -Watering.

CHAP. XIII.

* Where the quantity is confiderable, the information refpecting the crops commonly cultivated, may be arranged under the following heads:

1. Preparation $\left\{\begin{array}{l}\text { illare, } \\ \text { manure. }\end{array}\right\}$ 6. Culture whillt growing $\left\{\begin{array}{l}\text { hoe, } \\ \text { weeding } \\ \text { feeding. }\end{array}\right\}$

2. Sort.

7. Harve?t.

3. Steeping.

8. Threshing.

4. Seed (quantity fown).

5. 'Time of fowing.

9. Produce.

10. Manufacture of bread.

In gencral, the fane heads will fuit the following grains:

Karkey-Oats. - Beans.-Rye.-Peafe.-Buck-wheat.

$$
\begin{aligned}
& \text { Vetches . . Application. } \\
& \text { Crile-feed . . } \begin{array}{l}
\text { Feeding, } \\
\text { Sced. }
\end{array} \\
& \text { Turnips }\left\{\begin{array}{l}
\text { Drawn }: \cdots \\
\text { ked on grais } \\
\text { k in boutes }
\end{array}\right\}
\end{aligned}
$$


Chap. XIII. Live Stock.

SECT. 1.-Cattle.

2.-Sheep.

3.-Horfes, and their Ufe in Hufband-

ry, compared to Oxen.

4.- - Hogs.

5.-Rabbits.

6.-Poultry.

7.-Pigeons.

8.-Bees.

XIV. Rural CEconomy.

SECT.1.-Labour--Servants--LabourersHours of Labour.

2.-Provifions.

3.-Fuel.

XV. Political Economy, as connected with, or affecting Agriculture.

SECr. 1.-Roads.

2.-Canals.

3.-Fairs.

4.-Weekly Markets.

5.-Commerce.

6.-Manufactures.

7.-Poor.

8.-Population.

XVI. Obftacles to Improvement; includ. ing general Obfervations on Agricu! tural Legiflation and Police.

XVII. Mifcellaneous Obfervations.

SECr. 1.-Agricultural Societics. 2.-Weights and Meafures.

Conclufion.-Mcans of Improvement, and the Meafures calculated for that Purpofe. Appendix.

PERFECTION 
PERFECTION in fuch enquiries is not in the power of any body of men to obtain at once, whatever may be the extent of their views, or the vigour of their exertions. If Lewis XIV. eager to have his kingdom known, and poffeffed of boundlefs power to effect it, failed fo much in the attempt, that of all the provinces in his kingdom, only one was fo defcribed as to fecure the approbation of pofterity*; it will not be thought ftrange that a Board,

* See Voltaire's Age of Lewis XIV. vol. ii, p. 127, 128, edit. 1752 .

The following extract from that work will explain the circumftance above alluded to.

"Lewis had no Colbert, nor Louvois, when about the " year 1698, for the inftruktion of the Duke of Burgundy, he " ordered each of the intendants to draw up a particular de"fcription of his province. By this means, an exact account "of the kingdom might have been obtained, and a juft enu"meration of the inhabitants. It was an ufeful work, though " all the intendants had not the capacity and attention of "Monfieur de Lamoignon de Baville. Had what the King " directed been as well exccuted in regard to every province, "as it was by this magiftrate in the account of Languedoc, "the collection would have been one of the molt valuable "monuments of the age. Some of them are well done; but "the plan was irregular and imperfect, becaufe all the inten"dants were not reftrained to one and the fame. It were to "be withed, that each of them had given, in columns, the "number of inhabitants in each clction; the nobles, the ci"tizens, the labourers, the artifans, the mechanics; the cat- 
Board, poffeffed of means fo extremely limited, fhould find it difficult to reach even that degree of perfection which, perhaps, might have been attainable with more extenfive powers. The candid reader cannot expect, in thefe Reports, more than a certain portion of ufeful information, fo arranged as to render them a bafis for further and more detailed enquiries. The attention of the intelligent cultivators of the kingdom, however, will doubtlefs be excited, and the minds of men in general gradually brought to confider favourably of an undertaking, which will enable all to contribute to the national fiores of knowledgc, upon topics fo truly interefting as thofe which concern the Agricultural interefts of their country-interefts which, on juft principles, never can be improved, until the prefent ftate of the kingdom is fully known, and the means of its future improvement afcertained with minutenefs and accuracy.

"t tle of every kind; the good, the indifferent, and the bad "lands; all the clergy, regular and fecular, their revenues, " thofe of the towns, and thofe of the communities.

"All thefe heads, in molt of their accounts, are confufed "s and imperfect; and it is frequently neceffary to fearch with " great care and pains to find what is wanted. The defign 6: was excellent, and would have been of the greatelt ufe, had si it been executed with judgment and uniformity." 


\section{$P R E F A C E$,}

BY

\section{MR. KENT.}

\section{FlaVING come forward a Folunteer, upon} the establishment of the Board of Agriculture, and collected and arranged the best information in my power, touching the Iusbandry of this County, without any provincial bias, it was freely offered to the Board to be disposed of as it should think most likcly to produce any advantage to the Public. The Board very judiciously circulated it in all parts of the County, desiring all Persons, who might be inclined to take the subject under consideration, to make their free Remarks upon it, and to return it with any Additions they might hav'e to offer. In consequence of this, many sensible and pertinent Observations have been made, which the Board has since put into my hands, requesting me to re-print my own Report, and to interweave these Obser- 
vations with it. I shall with great satisfaction avail myself of the aid those Hints afford me, but as I shall, in several instances, enlarge my own original Report, I conceive it would tend to break the chain of my argument, and render it less intelligible, were I to blend these different opinions with it; at the same time, these Remarks will speak betier for themselves standing distinct. I mean, therefore, to publish such as are perfect in themselves, or too long for Notes, in an Appendix at the end of the Report, and such as are in the nature of short detached Observations, I shall subjoin at the end of each Section, taking the liberty to comment upon them with the same freedom that has been taken with me, but not any farther than may be necessary to illustrate the great and important object in question; thus we shall stand in the natire of evidence, and the Public will be the impartial Fury to decide upon the merits of our different icieas. And here I take the liberly to request the Reader to follow the full drift of my argument, through the whole of each Section, before he has recourse to the Notes; for though they will afterwards sirengthen and elucidate the subject, they will be apt to create perplexity, if recourse be had 
to them as often as their marks of reference appear.

As to the arrangement of the matter that will be contained in this re-printed Report, it will not follow in the exact form of the preceding general Plan, as the grealest part of my scheme was digested and setlled prior to my being acquainted with it; but I trust that under the following heads, I shall embrace all the material objects which the Board has pointed out.

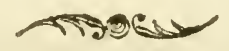

\section{ection}

I. PRELIMINARY OBSERVATIONS.

II. Situation, Contents, Divilions, and Population.

III. Climate and Weather.

IV. Surface and Soil.

V. Roads, Navigation, and Rivers.

VI. Manures and their Application.

VII. Tenures and their Proportions.

VIII. Arable Land and Courfe of Cropping.

IX. Modes of Culture.

$X$. Grafs Land, and Hints for its Improvement.

XI. Average Crops and Scale of Rent.

XII. Irregular Crops.

XIII. Fallowing exploded.

XIV. Common Fields and Inclofures.

$\mathrm{XV}$. The Commons confidered.

XVI. Woods and Plantations.

XVII. Live Stock. 
Sctioft

XVIII. Buildings and Repairs.

XIX. Implements of Hubandry.

XX. The Advantage of Leafes.

XXI. The Size of Farms confidered.

XXIl. The Advantage of Working Oxen.

XXIII. Commerce; or a Statement of Exportso

XXIV. General Outgoings.

XXY. Rural OEconomy.

XXVI. Fairs and Markets.

XXVII. State of the Poor.

XXVIII. Reprehenfible Practices.

IXIX. General Obfervations.

\section{$A \mathbb{P} \mathbb{E} \mathbb{N} \mathbb{D} X$.}

Letter from Sir Mordaunt Martin, Bart. on the Culture of P'otatoes.

Letter from Mr. Overman, on the Breed of Cattle.

Letter from Lord Petre, on the Fatting of Cattle with Oil, Bran, \&c.

Letter from J. B. Burroughes, Efq. on the Dibbling of Wheat.

Letter from Mr. Baler, on ditto.

Remarks by Mr. Tragfaff, on ditto,

Letter from Mír. Varlo, on ditto.

Remarks by Dr. Hinton, on the Advantage of Peat, Lime \&.c.

A Hint from Mr. WagfaIf, refpeding New Fences.

Letter from MIr. Kent, on the Advantages of Spanilh Chefnut: Abitract of Covenants between Mr. Coke and his Tenants.

Statement of the Expence and Profit of Eatting Scotch Catlie. 


\section{Agricultural Survey}

\section{OF \\ $\mathbb{N} O \mathbb{R} \mathbb{F} O \mathbb{L} \mathbb{K}$}

\section{Section I.}

\section{PRELIMINARY OBSERTATIONS.}

\section{arom}

1 HE fuperior benefits refulting to fociety from. Agriculture, are fo confpicuous, that it is imporfible they thould efcape the obfervation of a fpeculative mind. Other improvements, carry only lncal advantage; but thole of Agriculture are diffufive of general good to mankind. It is unqueftionably the firt of all fciences, as it nurfes and fupports the reft: it is therefore deferving the greatef encouragement from all ranks of men, who are able to promote its improvement, whether by liberal aid, indulry, or talents. 
tâlents. As an individual, I feel the utmolt fatisfaction, in making a free-will offering to the public of my mite of information on the prefent occafion, and am glad to find that Government has at laft fandioned this important object. By the aid it may receive from this refpectable quarter, and from the zeal and perfeverance of the active nembers who are placed at the head of the new eftablifhment, much may be cxpected; and as profeffional men from all diftricts, are called forth, to make their full and free obfervation upon the hufbandry of the parts with which they are moft familiar, it is to be prefumed, that a great deal of ufeful information will be brought together, after which a judicious felection will of courfe be made, highly to the advantage of the public; for as many men will, of courfe, defcribe the fame object, it will be undoubtedly necefiary, for the fake of brevity, to winnow the chaff from the corn, taking what is good from every man, and rejecting the drofs.

Thus, all who embark in this bufinefs, may have the fatisfaction to find, they contribute fomething, to the welfare of the great object on foot; and though the fubject they aim to de-

fcribe, 
fribe, may not be publifhed exactly in their o) win words, their ideas will at leaft be blended in the great body of the work.

The firlt object the Board feems to have in view, is to inform itfelf, of the prefent State of Hufbandry in every County, that it may give all the encouragement in its power, to fuch practices, which have a beneficial tendency, and endeavour to difcourage and put out of countenance, fuch as are carried on upon erroneous and obftinate principles.

There is no doubt, but great advantage will be derived from a plan of this fort. In the firft place, every foil in the kingdom will be defcribed, and its right ufe pointed out, which is the firt ftep to good hufbandry.

Cattle will, of courfe, be largely treated of, and the judicious farmer be enabled to diftinguifh how far he can rationally improve his native ftock, and how far mix the breed to advantage with cattle of another diftrict; and, at the fame time, a void the rock which a great number of people at this time fplit upon, in haftily changing their prefent ftock for another, per- 
haps ton large, and totally inappofite to the nature of the land.

Buildings will likewife be another confideration of great moment, as it is an object, that greatly affects the profit of eftates; therefore, the felection of the beft kind of materials, and the adoption of the belt plans, combined in comfort and frugality, will be found highly deferving the attention of the landed intereft.

Implements of hufbandry, will be found deferving the attention of farmers, and in many infances may be changed to advantage.

In thort, a thoufand ufeful fubjects and experiments will be treated on, fo largely, and fo fatisfactorily, (that nothing fallacious can be allowed to ftand, where fo many perfons, writing upon the fame fubject, muft correct each other) that there will be no occupier of land, but may derive fome additional knowledge to what he is now in puffeffion of ; for when all the beft and worft praclices are fairly exhibited, a perfon muft be deficient in common fenfe, not to adopt the one, and explode the other.

Nothing 
Nothing in my opinion, will tend more to excite a general fpirit of Improvement, than the Board's publifhing a general Abltract of all the beft Information that can be collected from the different Reports; contrafting the beft with the worft Practices. - A thort ftatement of this kind, drawn up with perfpicuity, will be more read, more attended to, and make a deeper impreffion on a Farmer's mind, than long defcription: from theoretical writers; but this felection fhould be made by a Committec of fix or feven men of found experience, who refide in different parts of the kingdom; and who, when called together, will be equally free of bias and local prejudice.

In order to facilitate what I here recommend, I will, in the courfe of my remarks, point out fome of the moft ftriking things which may be worth attention in a Norfolk Farmer, from better modes of hulbandry in other counties; and, on the other hand, point out, to other parts of England, fuch things as I conceive the farmers, in this county, excel in. 


\section{Section II.}

\section{SITUATION-CONTENTS-DIVISIONS AND POPULATION.}

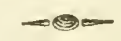

NORFOLK is a Maritime County, bounded by the German Ocean on the north and eaft; by Suffolk, fouth; and by Cambridgefhire and Lincolnfhire, weft.-Its greateft length, due eaft and weft, is fifty-nine miles, and its greateft breadth, from north to fouth, thirty-eight $(a)$. - At the ends it is not fo broad; but it may be confidered, when fquared, as containing, as nearly as can be afcertained from the maps hitherto publifhed, about 1,710 fquare miles, and 1,094,400 ftatute acres. It is divided into thirty-three hundreds, one city, by much the largeft in England, fave London and Brifol-Four fea port towns-Twenty-five other market-towns, and feven hundred and fifty-fix parihes.

It is extremely difficult to ftate, with any degree of accuracy, what are the different proportions of cultivated and uncultivated land, as this could only 
only be done by a general furvey, but from the beft enquiry and obfervation that I have been able to make, I will hazard the following calculation:

The fpace on which the towns ftand 1500 Public and private roads .... 16416 Lakes and rivers ....... 2000 Sedgy and fwampy ground .... 1500 Unimproved commens ..... 80000 WVoods and plantations ..... 10000 Arable land, computed at two- $\} 729600$ Meadows, parks, and upland palture i 26692 Marlh lands ....... $6334^{6}$ Warrens and theep-walks.... 63346

$$
\text { Total of acres - } \overline{1094400}
$$

The population of the city of Norwich was af a certained in the year 1693 , when it was found to contain 28,881 fouls; and again in 1752 , when it was found to have increaled to 36,169 ; but the trade was then in high reputation, and the city faid to be very healthy; and as the trade has fince rather declined, it cannot be fuppofed the pupulation has mach increafed fince, though it is generally underftood, that there are now about 40,000 fouls in Norwich (b), 10,000 in Lynn, and 16,000 at Yarmouth. 
As to the fmaller towns and villages, I have confidered them partly from a general average of houfes, and partly in proportion to the number of cultivated acres of land; and though calculations of this kind muft not be looked on as accurate, I confider the whole number of people in the county to be about $220,000(\mathrm{c})$.

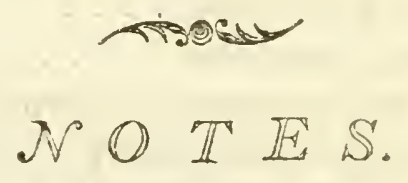

(a) Two commentators are to be noticed here, Sir Thomas Beevor and the Rev. Mr. Howlett, Vicar of Dunmow, in Efex-The former fays "by Templeman's Survey of the "Globe (a book of great authority) Norfolk is 57 miles in "length and 35 in breadth, containing 1426 fquare miles."-if Templeman meant, as I do, the mean length and breadih, the beft way, I prefume, of afcertaining the content fought for, he muft be in an error, for 57 , multiplied by 35 , will give 1995 miles-The latter fays "from a bare infpection of the maps of England, Norfolk is more extenfive than Effex, and yet that is eftimated at $1,240,000$ acres, and I believe that eftimate is very near the truth." - I truft that it will not imply, that my eftimate for Norfolk is erroneous, becaufe Mr. Howlett thinks that of Effex is true.-The fcale by which a kingdom is laid down cannot be depended upon for the adméafurement of a county.-Suffice it, that I have deduced my calculation, as I have before obferved, from the beft maps hitherto publifhed, and from twenty-fix years acquaintance with the county; and the public, muft decide to which ftatement molt credit is due.

(i) $\mathrm{Sir}$ 
(b) Sir Thomas ftates "that in 1786 the population of the "city of Norwich was again afcertained, and the number of "inhabitants was 40,$0 ; 1$, of which there are perfons having "fettlements in and belonging to other places, 10,85 t, and "that it is thought at this time that 8000 are in the workhoufes "ind hofpitals, or maintained elfewhere at the public expence."

(c) Mr. Howlett, who has taken great pains to afcertain this point in feveral parts of England, for which he is moft highly to be commended, is of opinion, that my ftatement is far fhort of the real number of people in Norfolk, which "he is "almoft confident was 270,000 ten years ago." In this remark he may poffibly be right, as, pcrhaps, his rule of computation may have been better than mine; fuffice it, that I have given the beft account which I could deduce from enquiry, checked by obfervation in parts where I was moft acquainted. But it is a very difficult queftion for an individual to afcertain with precifion, though I think it an enquiry of the very firft importance, and am aftonifhed that the government of this country has never made a point of obtaining it-Since it is obvious, that the greatelt benefit would be derived from it, not only in all commercial calculations upon allowable exports and profitable imports, but in referving fufficiency of corn, in due time, when there is likely to be any accidental deficiency; not to mention various other infances of mational advantage, which might be derived from a true ftate of population; it is alfo the beft foundation the Board of Agriculture can have to regulate the various plans of improvement it has in riew. 


\section{Section III.}

CLIMATE AND WEATHER.

I HE extremities of the county, lie from 52 deg. $24 \mathrm{~m}$. to $53 \mathrm{deg}$. $5 \mathrm{~m}$. north latitude, and from about 0 deg. $6 \mathrm{~m}$. to 1 degree 52 minutes of eaftern longitude; and being open to the German Ocean, north and eaft, and lying on the marthy parts of Cambridgefhire and Lincolnfhire on the weft-the air is on that account extremely cold in winter, and during the early parts of the fpring, vegetation is generally kept back by tharp eafterly winds, and a valt quantity of fleet-cattle on this account, often fuffer feverely as well from this inclemency of weather, as from want of a proper fupply of nourithment in the fpring; for when the turnips happen to perifh early, from the frequent change of froft and thaw, the farmer finds himfelf obliged to difpofe of his ftock to a very great difadvantage, which he fhould endeavour to guard againt, by keeping a good ftock of hay in ftore, and by fowing a fufficient quantity of his land, with rye or winter vetches the preceding autumn. In other refpects, I do not think the produce of the land the lefs for this feverity, on 
the contrary, it may be, and I believe is of advantage to it ; for nothing fertiiizes more than frolt and fnow, and as all the land defigned for the next year's crop of turnips is expofed to the weather the whole of the winter, it being the cuftom to plough up the fubble defigned for turnips fooner than in many other counties; it may perhaps be one reafon of the greater certainty in the culture of this ineftimable root.-In fummer, the thowers are rather more frequent than in the midland countics-ftorms and tempefts, fuch as thunder and lightning, are frequent, and as violent as in other parts of the kingdom, but feldom laft fo long as in hilly difriets, but in general pafs in a quick direction from the fouth and weft, towards the fea, which ftrongly attracts them; and I have remarked that it is but feldom that thefe ftorms come from the fea. 


\section{Section IV.}

\section{SURFACE AND SOIL.}

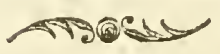

T

C HE furface, except in fome few parts, near Norwich, and upon the coaft near Sherringham and Cromer, is moftly a dead flat; confequently, the afpect is in general uniform and uninterefting, and, as the open and worlt parts lie to the fouthweft, where flangers enter the county, it mufi offer to them a very dreary and barren appearance (a), but all the north, north-ealt and fouth-eaft parts are incloled; and being as well, if not better, cultivated than any other part of the kingdom, and certainly much richer in timber than any other maritime county, exhibit at leaft many cheerful and plealant views, but none that are very extenfive.

The greateft part of the arable land is fandy. The prime parts of the county lie north and northeaft of Norwich; comprifing the hundreds of Eant and Weft Fiegg, South Walfham, Blofield, Happing, Tunftead, and the greatent part of North and South Erpingham; all which may be denominated 
minated a true fandy loam, equal in value to the beft parts of the Auftrian Netherlands, to which it is fimilar. It is highly fruitful, and fo temperate and pleafant to work, that it is rarely injured by wet or drought, fo that the occupier is feldom put out of his rotation of cropping. It is very unlucky for the credit of Norfolk, that this part of the county is, by its diftant fituation, lefs lnown to ftrangers than any other part.

The diftrict fouth and fouth-eaft of Norwich, confifting of the hundreds of Loddon, Clavering (b), Hen?tead, Earham, Difs, Depwade, and Hurnilyard, as well as fome parts of Fourhoe and Mitford, though chiefly fand, have an occafional mixture of clay, and are in many parts wet and full of fprings; but yet thefe parts are fruitful, though to a lefs degree than the former; they are likewife lefs pleafant and more expenfive to work.

The largent portion of the county lies wert and and north-weft of Norwich; comprifing the hundreds of Taverham, Eynsford, Holt, North Greenhoe, Gailow, Launditch, Brothercrols, Smithdon, Freebridge, and Clackclofe. There is fome very good land in different parts of this diftrict; but, upon the whole, it is a very inferior country to the two prcceding diftricts. It rums, in general, light, and its belt dependence is mpon the fold. This is 
what is called Welt Norfolk, and is the part which Mr. Young defcribed in his firt Norfolk Tour; and on account of the three great houfes of Holkham, Houghton, and Rainham, is the part which frrangers are moft acquainted with. It is here that great farms are to be found, with a thin population (c); and if it were not for the occafional affiftance derived from the eaftern part of the county, there would often be a want of hands in the harveft, and other bufy feafons (d).

The hundreds of Shropham, Guiltcrofs, Weyland, South Greenhoe, and Grimfoe, lying fouth-weft of Norwich, run upon a fill lighter fand; fo light, that in the laft mentioned hundred, the fand very often, in a high wind, drifts from one parifh to another. This is the part where the great rabbit warrens are found, which upon this foil pay better than any other thing the land could be appropriated to.

Marfhland may be confidered as a hundred by itfelf. The foil is a rich ooze, evidently a depofit from the fea: the north part is highly productive; but the fouth part very much injured for want of better drainage, which, it is prefumed, will now be effected, as there was a bill paffed in the laft fefo fion of parliament for that purpofe. 


\section{$N O \mathbb{I} \mathbb{S}$.}

(a) Sir Thomas Boevor obferics, "that many ftrangers end "ter the county by way of Colchefter, which brings them "through a fine rich country ;" this I readily admit, and that there is no road of equal length with that, from London to Norwich, where there is lefs uncultivated land or better hufo bandry; but the number of travellers who come this way are very few in proportion to thofe who come by Newmarket and Thetford.

(b) Sir Thomas fays, "the hundreds of Henftead, Forchoc, "Mitford, Difs, and Depwade, particularly the two lafts "confit almoft wholly of ftiff wet land, many villages havin: "fome land which may be called a mere clay."-I have admitted that part of them are wet and full of fprings, and that they have a mixture of clay. In general defcriptions of this fort, every thing is comparative. If we contraft this diftrict with the reft of the county, which is confeffedly fandy, Sir Thomas may be right, but compared with Herefordhire, the Vale of Evefham, and other fimilar difricts, where abfolute clays abound, I Atill prefume to think I may be right.

(c) Mr. James and Mr. Wagftaff have in this place taken notice of the bad tendency of large farms, but as I intend to handle that fubject in a diftinet fection, I thall hereafter avail myfelf of their judicious rcmarks upon that great queftion. 


\section{Section V.}

ILADS, NATTGATION, S RIVERS.

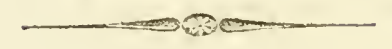

THE, roads in this county, afford the farmer as very great advantage over many other parts of England, being free from lloughs, in all parts (excent the marfies), and though the foil is fandy, it sefilts the prefiure of the wheels at a fmall diflance from the furface, and the ruts are kept fhallow at a very litile expence; and after the longen and hard. cft rain, become dry and pleafant in a few days, which is not only an agreeable circumftance to a traveller, but a grcat comfort to cattle in their drift; fo that I may venture to fay, that the roads are better, in thei: natural ftate, than in almon any other county; fo good, that no turnpike was thought of in Norfolk, till they became common in molt other parts; fo good, that Charles II. when he honoured the Earl of Yarmouth with a vifit at Oxnead, is faid to have obferved $(a)$, that Norfolk ought to be cut out in flips, to make roads for the refi of the kingdom; by which he undoubiediy meant to compliment the county upon the goodnels 
goodnefs of its roads, above other counties. In fhort, the roads, though often called bad by Norfolk men, are fo good, comparatively with thofe in other counties, that where the common ftatute duty is fairly done, a traveller may crofs the country in any direction, in a poft-chaife, without danger; and where the duty is not done, may trot his horfe from one parifh to another, at the rate of fix miles an hour.

The fea navigation is undoubtedly another great advantage to the agriculture of this county, as it not only enables the farmer to avail himfelf of the level of diftant markets, but in many inftances enables him to procure an additional quantity of valuable manure. The county is bounded by the fea from Yarmouth to the mouth of the Nene, being eighty miles, and there are four confiderable fea-ports, independent of feveral fmaller places, of landing and fhipping of goods: but as I fhall have occafion to fay a word or two, refpecting trade, under the head of commerce, I thall wave that fubject in this place.

The principal rivers are the Ouze, the Waveney, the Yare, the Wenfum, and the Bure. The Great Oure is narigable from Lynn, twenty-four miles through the county, and then communicates with feven of the Midland counties; the Little Ouze Lanncles cut of the Great Ouze, and is navigable by 
Brandon to Thetford (a); the Waveney from Yarmouth by Beccles to Bungay; the Yare and Wenfum from Yarmouth to the populous city of Norwich; and the Bure from Yarmouth to Aylham : befides which, there are feveral fmall cuts to private eflates.

Thefe inland navigations are of great ufe to individuals, and to fociety at large-they give aid to agriculture, and fpirit to trade; and tend toleffen the number of horfes, which are the greateft devourers of the produce of the earth: I could therefore wifh to fee them improved upon, and extended as far as poffible, and it is a confideration worth the attention of the gentlemen of the county.

The molt obvious improvement of this fort, which prefents itfelf, is that of extending the navigation of the Wenfum from Norwich to Fakenham, which I believe is not only practicable, but would be found to anfwer the expence extremely well, as it would pafs through a corn country the whole way, from which the corn is now conveyed a vaft way by land carriage: I am told there were formerly fome ftcps taken towards effecting this defrrable object. I an at a lofs to know why it failed of fuccefs, but thould be glad to fee it revived without lors of time.

There is another great object of inland navigation, which pcrhaps deferves ftill greater attention. 
For this hint I am indebted to $\mathrm{Mr}$. Colhoun, whofe letter upon the fubject to Sir John Sinclair, is clear, fenfible, and fo much to the purpofe, that I Thall take the liberty of making a large extract from it, with which I fhall conclude this fection. - "A "plan was offered to parliament about five years "fince, (but was rejected) by which it was pro"pofed to make a canal from the Brandon river, "by Newmarket and Saffron Walden, to London. "It would have added more confiderable advantage "to the county of Norfolk, than arifes from any "of the river navigations before enumerated. The "ports of Lymn and London would have been "united, by an eafy accefs to each other in the "courfe of a few days, to the mutual benefit of "both; and in time of war, the eaft country trade "would have found many inducements to make the "port of Lynn, in order to pafs from thence to "London, thereby faving fome rifk of the fea, "and danger from the enemy. The exuberant "produce of the county, would have had a cheap " and expeditious transfer to the metropolis, where. "thefe fupplies are fo effential to the fupport of its " inhabitants, that without them they cannot exif. "It appears by Mr. Kent's report, that the export "of corn, grain, and flour, from Norfolk, is about " 600,000 quarters annually, the greateft part goes " to the London market. It is eafier to conceive "than lay down a rule, whereby to calculate all the " benefit a country, fo rich in produce, would derive $\mathrm{C}_{2}$ "from 
"from fuch a communication with diftant markets. "The eftimate of faving in the price of land car"riage alone, is not exaggerated if taken at 200,0001 . " a year, befides the faving to arife in the various "articles of merchandize, now carried in wagons "to and from Londun. To demonftrate this, it "will be enough to flate, that the price of land "carriage from Thetford (fituate on the Brandon " river) to London, or back, is 41 . a ton; and by "the propofed canal, the calculation was under "20s. - a faving of near eighty percent. The like "faving would have been made on all the articles " of trade, extending to the city of Norwich, and " every other place north of Thetford.

"If this bufinefs is again brought forward, I " hope and truit there will be no exertions of in"fluence, to obfruet a canal that muft be fo advan"tageous to the public, and, at the fame time, en"courage the agriculture of a county, that has al"ready diftinguifhed itfeIf, beyond any other in the "kingdom."

Mr. Colhoun adds, "that white bricks, fimilar "to thole of Norfolk Houfe, are made near the "propofed canal, and would be delivered at one" half the prefent price of that article in London." 


\section{$\mathbb{N} \bigcirc \mathbb{T} \mathbb{S}$.}

(a) Sir Thomas Beevor fays, "might not this mean, that s? the foil was fo dry and barren, as to be unfit for any other "ure than that of roads? In this fenfe it has been by writers "always underfood." If the furface had been a hot hungry gravel, the King's meaning might have been as Sir Thomas feems inclined to confrue it, but as it is chiefly a fand, it is not reafonable to fuppofe he would have confidered that as the belt material for road making. Befides, though the cultivation and produce of Norfolk was not then equal to what it now is, there is a frong prefumption to fuppole, that it was at leaft upon an equal footing with the reft of the kingdom; indeed, I am very much inclincd to think it was, even then, upon a fuperior footing, on account of its proximity to Flanders, from whence our earlieft leflons upon good lufbandry were brought.

(b) Mr. Fox makes a very pertinent obfervation in this place, which it is incumbent on me to infert at length. He fay's, "the diftance from Thetford to Bungay being but thirtw"two miles, it feems, that a canal from one place to the other, "would effentially benefit the whole county, as the ftreams of "the Ouze and the Waveney flow towards each other, fo as to "leffen the diftance above fated fome miles. It is fubmitted that "this navigation might be eafly effected; commerce would then " circulate round the whole county, and confequently throw "its treafures into the heart of this and the neighbouring coun"s ties." I am quite of Mr. Fox's opinion; think this a very eafy thing to accomplifh, as the fources of the two rivers are only a few miles apart, and it would be as beneficial to the north fide of Suffolk, as to the fouth fide of Norfolk, from whence the corn in many places is now carricd to Ipfwich market, full twenty milcs by land carriage. 


\section{Section VI.}

WANURES AND THEIR APPLICATION.

D 1 ANURING land is in all places a neceffary part of hufbandry-rich land will not yicld a long fucceffion of crops without help-and poor land requires it in the very out fet of its culture-confequently the eafier this article can be obtained-the greater is the advantage which a country derives from it.

Marl is in general not only one of the belt fpecies of manure, but one of the moft lafting; and the marl of this county is a treafure to it, beyond what many others counties poffefs; for though there are large fratums of marl in moft other counties, I have never feen any of fo good a quality, or fo eafy to be got at, as it is to be found in molt parts of this county, and in many places very near the furface. Mr. Marfhall, in his Rural OEconomy of Norfolk, a work of great merit, defcribes two forts of marl, and enters into a chemical inveftigation of their natures. Suffice it, on the prefent occafion, 
to fay, that it is of ineflimable value. Tivelve cart loads $(a)$ to an acre of the white, or rather yellow marl, will, the fecond year alter it is laid on, change the nature of land; moft of the exhaulting weeds which impoverifh the foil, and choak the corn in its infancy, are effectually deftroyed (b), as it has a great tendency to keep land clean; it braces the pores of the earth clofer together, and increafes its fertility to a furprifing degree; its bencfit, though not to the effect it produces at firft, is felt for thirty years, when a fecond marling, of about half the original quantity, may with propriety be uled; but it has been found by experience, that it does beft the fecond time compounded with muck or maiden earth. I thould add, that as it is of a ponderous nature, it fuits beft when fpread on lay land, by whiclz means it mixes fooner, and better, with the native foil.

The other fpecies of marl is, more properly fpeaking, a clay, impregnated with marly particles, and though good in quality, is certainly much inferior to the other, as it requires more than double the quantity to carry the fame improvement. But I am inclined to think, this laft is more durable than the former, not, however, from its quality, but from its mixing better with the earth, and not efcaping downwards fo foon.

There are likewife, in fome parts of the county; depofits of a brown and bluifl clay, which make 
great improvement upon the light fands, but thofe do not lie in fub-ftratums, like the marl in mof parts of the county, but are only found in local fpets, and fometimes difcovered in the fea-banks.

Thofe farmers who live near the fea, have lately began 10 make ufe of the fmall fand from the beach, which they lay in the bottom of their yards, and when their muck, which is made upon it, is fufficiently rotten, turn up the whole and mix it together; but the more general practice is, to lay it a foot deep in the fables, during the fummer, and to feed their horfes with green vetches, in the itables, the dung of which, being afterwards mixed up with the fand, makes a moft excellent manure, as well for grafs, as arable land.

Thefe are the chief natural advantages, which are pofferfed by this county.

River weeds, (an excellent manure for turnips) foot, malt duft, and many other fimilar articles, it has in common with other parts of England, with which it is likewife upon an equal footing, refpect. ing the ordinary proportion of vegetable and animal manure, arifing from their crops and fock.But a more general advantage might be obtained, than what is now the practice, by imitating the farmers of Effex, in turning up the borders of their corn-fields, and the banks of maiden earth in the roads, 
roads, and mixing them with their common yard - muck, - which would multiply thair quantity of manure exceedingly, and do no manner of injury to the fields or roads; but by lowering the ground at the fides of the fences, (where nothing of profit grows) help to let the furface water into the ditches the eafier.

There is another fource, which I here offer more particularly to gentlemen who are in poffeffion of parks, plantations, and lands in hand, and that is, to caufe a permanent'fold, during the wifnter months, to be pitched, in fome fheltered fpot, near their woods, and to pen their ftore flock in it, giving the theep the quantity of hay they are accuftomed to have, in racks, in the fold, and littering it every night with frefh leaves of trees; with ruhes, mols, or any other fimilar rubbifh that can be collected; this tmrned up together, in the month of April, and mixed with about one-fixth part of lime, rubble from old walls, or any fort of afhes, will make as good a fort of manure as can be laid on turnips-and the quantity will be very conficerable: fuffice it, that on one of His Majefty's farms at Windfor, I made, in one winter, fix hundred cart loads from fix hundred Theep. Every gentleman, however, who trics this, mult fet out with a determination not to be defeated by the prejudice or obfinacy of their bailiffs and fhepherds, who will endeavour to perfuade them out of it, by fuggefting, 
that it will not anfwer the expence, and that it will injure the fheep, which laft will be an affertion without the leaft foundation in truth.

I cannot quit this fubject without taking notice of a very important hint, given by Dr. Hinton, of Northwold, near Stoke, upon the fubject of peat and lime, which he recommends to be ufed as manures. His letter upon this, and fome other fub. jects, is too valuable to be fuppreffed, I fhall therefore take the liberty to publifh it at length, in the Appendix, and have only to add, by way of ftrengthening his argument, that $I$ am of opinion no manure whatever can be more fuitable on clover, laid on early in the fpring, which, in general, not only adds greatly to the crop of hay when mowed, but infures a good crop of wheat in fucceffion-it is likewife peculiarly good upon faint-foin, and, I thould apprehend, well adapted for turnips: as to lime, I am of opinion, that it is always beft to compound it with fome other fubftance, and with maiden earth in preference to any other. 


\section{$\mathbb{N} O \mathbb{T} \mathbb{E}$}

(a) Dr. Temple fays, "twelve loads is too fmall a quan"tity, I Thould apprehend; an hundred loads, with ten " or tweive of muck, would be much better, if the foil is of "a light fandy texture, and if it be clay, then it requires four "or five times the quantity." I do not fay, that twelve loads are of fo much value as more would be, but ftate it as a faet, that twelve loads have the effect I defcribe, which the Doctor cannot deny. It muit have been in Staffordfhire, or Chefhire, where the Doctor has feen this vaft quantity laid on, where I believe it to be the cuftom; but if twelve loads of marl will do as much here, as an hundred there, it proves the fuperior quality of the Norfolk marl, and makes for my argument, that it is a peculiar treafure to this county, which was all that I prefumed to advance: however, I will venture to affert, that the quantity the Doctor recommends, would entire. ly ruin the Norfolk foil.

(b) Mr. Strachey, Member for Bifhop's Caftle, fays, "this "being a fact, perhaps fome philofophical account might be "inferted, to fhew, why weeds muft be deftroyed by marl, "though it caufes other plants to vegctate and flourifh." I hope this remark, which is a very pertinent one on the occafion, will excite the attention of fome perfon capable of anficering the queftion. 


\section{Section VII.}

\section{TENURES AND THEIR PROPOR-} TIONS:

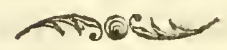

If $\mathrm{T}$ is almoft impoffible to give the different proportions of each tenure, in fo extenfive a county as Norfolk; I mutt therefore be allowed to take it. partly upon conjecture, and partly upon a compa-. rative examination of the particular diftricts with which I am moit acquainted; from which, I fhall make the following deductions :-

The copyhold is of two forts, the one fubject to, what is called here, an arbitrary fine, that is, a fine at the will of the lord, who, upon fuch eftates; generally takes near two years value on defcent, and a year and a half on alienation:- this copyhold is confidered in value, about five years thort of freehold. The other copyhold, is only fubject to a fine certain, fo that a lord of a manor can feldom take more than four fhillings an acre, and fometimes only fixpence:-this is rearly of equal value to freehold. 
The money rents are, in moft inftances, eafy and light, but a corn rent is fometimes relerved, which comes heavy.

Heriots, generally fpeaking, are not known in this county, which is a happy circumfance, as they: are, unqueftionably, the mon cruel badges that remain of the ancient feudal fyltem.

There is fome leafehold; for terms of years, under the bifhop and dean and chapter of Norwich, and corporate bodies; fome little under other ecclefraftical and collegiate bodies, not refident in the county; but very little on lives, and that littie only under the church or colleges.

The practice which lay-lords have of leafing their eftates upon lives, in the weftern counties, is in no inftance, that I know of, followed in this county; though it is to be much wifhed, that it was the cuftom with refpect to cottages, as it would be the beft means of making them more comfortable than they are.

Confidering the whole of the county, perhaps I fhall not be much wide of truth, if I llate the freehold lands to be three-fifths; the chureh, collegiate, and corporate eftates, at one other fifth; and the remaing fifth copyhold, under lay-loids. 
With refpect to obfervation upon the effect of thefe different tenures, I thall, perhaps, appear unpopular, in the eyes of thofe whofe doctrine it is to recommend throwing large tracts of land into a few hands, if I prefume to fay, that I think, fince the flavery of the ancient feudal fyftem has been abolifhed, and the courts of law have difcouraged excefilve fines and immoderate heriots, moft of thefe fubordinate tenures have their advantage in fociety; by keeping up a fort of barrier againft the monopoly of land, they tend to keep eftates diftinct, and preferve fome lots of land, to which fmall capitals and induftry are moft applicable. This is undoubtcdly a great argument in favor of collegiate and corporate tenures, for as thefe bodies have at moft only a life interef in the eftates, a life no fooner drops, by which the eftates are held, than they are ready to renew with the leffee by adding another, and in general upon fair conditions.

This is not fo, under a lay-lord, whofe object is to form a great freehold eftate, by annihilating thefe fmaller objects. - It is, however, to be wifhed, that the ftewards, who hold the courts in this county, could be taught a little moderation in fetting their fees; which are higher in general than in any nther county I am acquainted with.-It might alfo be further urged in fupport of thefe tenures, that a copyholder or leffee, on lives, having his own life, and perhaps that of a wife and child in his 
eftate, is naturally encouraged to make more folid improvements upon his land, than where he is only tenant at will, or upon a fhort term of years. - He will alfo be better enabled, in the firft inftance, to marry, and much encouraged to do it, becaufe he has a more certain profpect of fupporting a family; for, in cafe of his own death, his wife or child would not be deprived of the poffeffion.-Thofe who deny the force of this argument muft, I think, wilfully thut their fenfes againft reafon and conviction.

Another fair argument in favour of copyhold is, the greater certainty of its title, and the cheapnefs of its conveyance compared to that of freehold, which is no trifling confideration. 


\title{
Section VIII.
}

\section{ARABLE LANDD, AND COURSE OF CROPPING.}

\begin{abstract}
IN my general eftimation of the quantity of arable land, I have fuppofed the whole to be about iwo-thirds of the county, or 729,600 acres, of which, perhaps, about three parts out of the four may be inclofed; the other fourth part in common ficlds.
\end{abstract}

The landlord generally withes to fix the management and courfe of cropping under a fixcourfe fhift, viz. wheat the firft year-barley or oats the fecond, without clover-turnips the third -barley or oats, with clover, the fourth-the clover mowed for hay the fifth-and the fixth grazed till Midfummer, and then broken up for wheat in fucceffion.

But the occupier will often endeavour to contract it to a five-courfe fhift, by fowing his wheat upon clover of one year's lay, and in fome of the beft 
parts, as in the Flegg, Tunfead, and Blofield hundreds, fome tenants carry on only a four-courfe fhift: thus, wheat, turnips, barley, and clover. This laft, is fimilar to the practice of great part of Flanders, where the invariable method is, to carry an alternate crop for man and beaft, but as land, though ever fo good, will grow tired of a too frequent repetition of turnips and clover (a), fome inconvenience is occafionally fuftained; to remedy which, they will do well to change the former of thefe, now and then, for a vetch crop, and the latter for trefoil or lucern. - No courfe of hufbandry can be more profitable than this, where the foil will allow it; and there are many parts of this county where it may be carried on without doing any injury to the land. I confider the five-courfe Shift to be more unfair than the four; becaufe, in this cale, there are three crops of corn, to two crops for the animal. This mode of cropping would be better, if the barley crop, after wheat, was fometimes changed for buck wheat, or potatoes, which would neither be an unprofitable or exliaufting crop; and thus a little varied, the practice of a five-courfe cropping might be allowed, in the parts where the foil is good in quality; or where any extraquantity of manure can be procured, which is fometimes the cale in the vicinity of towns, or near fea or river navigations, or where a gentleman occupies a park with a farm, or a farmer a large portion of down; but in the great weitern parts of the county, 
the courfe of fix thifts ought to be frictly adhered to ; and there is fomething very rational in this fixrourfe hufbandry upon a light foil, for though the exhaufting and fertilizing crops, do not follow alternately, as in the four-courfe fhift, yet there is an equal number of each obferved in the rotation. I think, however, in the very light parts of the county, that a feven-courfe fhift would be an inprovement, but I do not mean by letting the land remain three years laid, as fome have recommended, becaufe the Norfolk land does not yield much profit from grafs feeds after the firft year: but I would rather recommend the following courfe:-wheat, vetches, barley, buck, turnips, barley, clover $(b)$; this would keep the turnips and clover crops at fuch a diftance, that there would be no fear of their fuccefs; and, as the buck might be confidered as a neutral crop, the alternate advantage would not, in fact, be loft in its good effect. I believe too, that by means. of the vetches, which might be fed off the whole fummer, more fock would be kept on very light land, than from the prefent fix-courfe Ihift; and where a flock is kept, it never can bc employed fo well, as in penning upon this fort of light land, as foon as the wheat or rye be fown, efpecially if the fowing be upon one ploughing; in. fuch cafe, it is beft to begin rather early, and fow by degrees, as many ridges each time, as the breadth of the fold will cover. 


\section{$\mathcal{N} O \mathbb{T} \mathbb{E}$.}

(a) Sir Thomas Beevor remarks in this place, that the compldint I here allude to, is not known in the part of Norfolis where he refides, which I ain glad to hear; but, I am forry to fay, that in all parts where I am molt familiar, it is otherwife. Sir Thomas's obfervation is as follows:- Such com"iplaint refpecting turnips is perfectly new, to the writer of "thefe remarks, around whom, the farmers in the hundreds " of Humilyard, Henftead, and Depwade, cummonly ufing " the four-courfe thift of an alternate crop for man and beaft, "have felt no fuch mifchicf. This mode of hupandry, there"fore, cannot be too ftrongly recommended, as it will not "only keep the land clean from weeds, enable the farmer to " keep a larger ftock of catte, (from which he raifes his ma. "nure, thereby enfuring himfelf a greater producc of corn,) "but, it is alfo advantageous, by dividing the work upon the "farms into fuch portions, as require to be attended to, at ": different periods of the year, whereby the bufincts is car"ried on with lefs luurry, as weil as with fewer horfes and "men."

(b) Mr. Baillie obferves, "In this rotation, there is nothing "to keep ftock upon in fummer, efpecially fheep." What better feed can theep have than vetches? which would be on one-feventh part of the farm, and might be eaten off the whole of the fummer, belides the feed of the clover, after mowing it for hay. 


\section{Section IX.}

\section{MODESOF CULTURE.}

PLOUGHING is certainly done with much greater eale in this county than any other, and much cheaper, as it does not ftand the farmer in above $4 \mathrm{~s}$. an acre for each tilth. There is no inftance of more than two horfes being put to a plough: the fame perfon who holds the plough drives the horfes alfo with reins. friptive jetch of it.

The horfes are thort and compact, but active and hardy, and feldom exceed fifteen hands. Inflead of working them feven hours in winter and eight in fummer, as they do in molt other counties, without drawing their bits, they are worked eight hours in winter and ten in fummer, by two journies as they are termed, which enable them to do confiderably more than they would by one journey, as it is evident that a horfe would go two twelve-mile ftages a-day upon the road, with as much e fe, for a conftancy, as he would twenty miles at one ftage; befides, the heat in fummer is more avoided by this means. The common day's work 


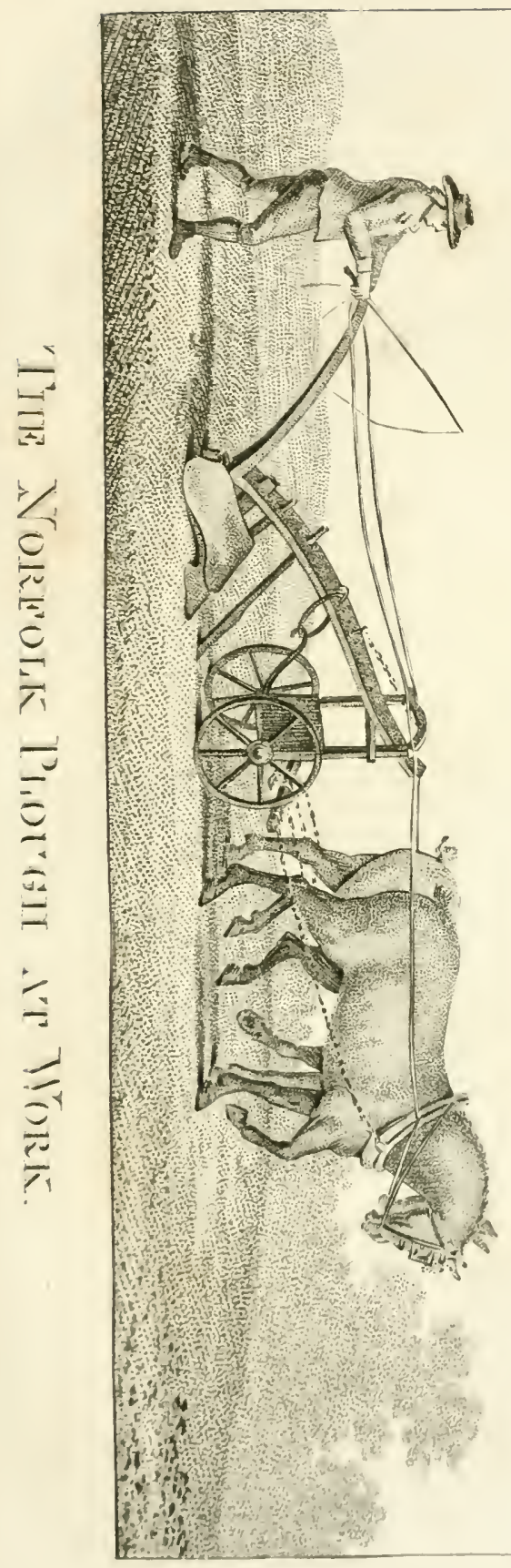



work for two horfes is a flatute acre, and, in times of feeding, it is very common to plough an acre and an half.

One man looks after four horfes and drives two of them; the other two are driven by a day labourer, who does little jobs about the yard, at the interval, while his horfes reft, and in the evening. This mode is worth imitation in all other light parts of England.

As ploughing is done here with fo much eafe, it is an encouragement to the farmer to give it the more tilths, which, in fome meafure accounts for the land being fo clear ; but I apprehend there is another realon, which is, the fhallow ploughing obferved in this county, compared with many other parts of England. Land is undoubtedly kept cleaner $(a)$ by fhallow than deep ploughing, and, in light land, the moifture is more preferved by having a pan at the bottom; and there is likewile a much lefs body of earth to manure and keep in heart. The great fecret with ploughed land feems to be in keeping it fo clean that nothing thall grow but what is fown upon it; and to keep the furface in a pulverized fate, fo as to be open and mellow to receive benefit from the influence of the atmofphere. 
In treating of the procefs in feeding, I thall begin with wheat. This is partly dibbled and partly fown broad-cant the former is not in fo high eftimation as it was fome years fince; but I am of opinion, that when wheat is planted upon clover of only one year's lay, it is the beft practice, efpecially if the dibblers are well looked after, for in this cafe it will admit of a faving of a bufhel of corn to an acre. This faving is an important advantage, as a bufhel of wheat is enough to fupport a man two months, as the average confumption is fix buthels a-ycar to every human mouth (b); and if we value the bufhel of wheat which is faved, at fix fhillings, the farmer is only four and fixpence out of pocket, as he can have it done very well for half-a-guinea an acre, and the corn is generally better bodied, and fomewhat heavier. For better information upon this commendable practice, I beg leave to refer my readers to the letters of John Burkin Burroughes, Elq. Mr. Wagftaff, Mr. Baker, and Mr. Varlo, in the Appendix, where the method is fully explained; and I hope other counties will not fail in adopting it.

When wheat is fown upon one year's lay, it never has but one ploughing; and when it is fown upon a fecond year's lay, it feldom has but two. The old practice was, to break up the fecond year's lay foon after the fpring grafs was eaten off; 
but now it is feldom touched till after Lammas, and then the beft way is juft to pare up part of the fward by a fort of half ploughing crofs the ridges, juft curling the ploughed part over the unbroken part, in an inverted ftate, and, when the turf is deadened, to crols-harrow it; and at the wheatfeeding to plough it up, in the ftraight way of the ridges, to its full and proper depth. The turf by this means falls to the bottom, and operates as an affitant manure. I have nothing to recommend in addition to this practice, but that the farmer fhould take care not to be too late; as it has been remarked, that, as near the time as pofible that nature fheds any particular feed, it always grows with more certainty $(c)$, and therefore lefs feed is required, when fown early, than when fown late: about Michaelmas is the height of the feafon here; it never fhould be delayed above a fortnight after.

The barley is, at all times, put into the ground in excellent condition. When it follows whear, the ftubble generally has turnips thrown upon it ill Chrifmas, when it is fcale ploughed in two furrow ridges; and afterwards has four earths.

But the great piece of hulbandry in which Norfolk excels, is in the management of turnips, from which it derives an ineftimable advantage. This important crop is the great fource of abundance to the country, and has been graduaily rifing to per- 
fection in its cultivation, for upwards of feventy years. Not only this county, but many other parts of England, are indebted to the Townfhend family, for the original introduction of this root into this country. Before that time, turnips were only cultivated in gardens and fmall fpots, and hoed by gardeners; but in the reign of Gcorge I. the then Lord Vifcount Townfhend, grandfather of the prelent noble Marquis, attended the King to Hanover, in the quality of Secretary of State, and obferving the advantage of this valuable root, as there cultivated at that time, and the fertility it produced, brought the feed and practice into England, and recommended it ftrongly to his own tesants, who occupied a fimilar foil to that of Hanover. The experiment fucceeded, and by degrees, it gradually fpread over this county, and, in the courfe of time, to other parts of England, though their cultivation is by no means fo general as it coninues here. A good acre of turnips in Norfolk will produce between thirty and forty cart loads, as heavy as three horfes can draw; and an acre will fat a Scotch bullock(d), from forty to fifty ftone, or eight theep.-But the advantage of this crop does not end here, for it gererally leaves the land fo clean, and in fuch fine condition, that it almoft infures a good crop of barley and a kind plant of clover; and the clover is a molt excellent preparative for wheat, fo that in the fubfequent advantages, the value of the turnip can hardly be eftimated. 
I wilh I could clofe this thort hiftory of turnips, without lamenting, that the ground does not relifh them fo well as formerly, fo that great care is neceffary in raifing them, and more feed is required; and after all, it is a teafing and precarious crop, and admits of no certain rules to enfure abfolute fuccefs; though fome cautions may be worth ftating in this place. The firft ploughing thould not be later than Chriftmas, and hould be to its full depth, unlefs the land is foul, in which cafe it fhould be ploughed very fhallow the firt time, in two furrow ridges, and the fecond time to the full depth; but it fhould never be ploughed in wet weather. After the firft fallow has received the benefit of the froft and fnow, it fhould be harrowed down in March. The next ploughing fhould be as foon as the bariey fowing is over, and it fhould have five earths in all; the laft ploughing but one, the dung is ploughed in very thallow, and rolled down; and the laft hould be about a fortnight after, not later, as the muck will about that time begin to ferment. About twelve loads to an acre is a proper dreffing. There is, perhaps, no part of hurbandry more deferving of imitation by the reft of England than this (e). Some perfons ufe rape-cake for turnip manure; and Mr. Styleman, of Snettifham, a gentleman of confiderable fortune, who farms part of his eftate upon a large fcale, and is trying many ingenious expcriments, ufes it in a pulverized flate, to which he reduces it by means 
of two mills, wo:ked by two women, each mill being formed of two cylinders, revolving towards each other. The firf breaks the cake into pieces of the fize of a wainut, by the operation of cogged cylinders; the fecond is conftructed of plain caftiron cylinders, finilar to thofe ufed for grinding clay to make bricks. Thus reduced to powder, he puts it into the very drills, where he had juft before depofited the turnip feed, by means of Cook's machine, which requires no other contrivance or alteration, than fubftituting different cups and funnels. The quantity of cake ufed is a quarter of a ton per acre, which has never exceeded $11.5 \mathrm{~s}$. in its price. He affured me, that this method had never failed to infure him a good crop, and that it does equally well for wheat.

River weeds and fedge, have larely been ufer to very great effect, for turnips, by Mr. Coke, and Mr. Branthwaite, of Taverham, who aflure nne, that no manure whatever anfwers better. They are frewed on the ground, in their wet flate, as foon as they are taken out of the water; if the land be of a diy nature, there is no fear of any aquatic feeds taking root in $i t$; but if the land be of a cold or wet nature, abounding in fprings, I fhould think this manure ought to be ufed with great caution. 
Having fated, that turnips came into this country from Hanover, one would naturally expect, that they were managed to great perfection there, at this time; but I doubt this is not the cafe, for I had this fummer the honour to be introduced to a very intelligent Hanoverian nobleman, at Windfor, Count Hardenberg, who was very inquifitive into the ftate of Agriculture in England, and upon my converfing with him about turnips, I found that they did not know the ufe of them there, at this time fo well as we do, which is a matter of furprife, that an article of fuch great benefit fhould ever decline in repute; I doubt it muft have arifen from the ground growing tired of them; for which reafon, I recommend our Englifh farmer to break the fucceffion of the crops, now and then, by fubftituting vetches, or potatoes, in lieu of them, which may be eafily done without interruption to the fucceffion of his corn crops; and by this means, I am of opinion, this moft valuable root may be permanently eftablifhed in our fyftem of Agriculture.

Hoeing is another effential part of the culture, which is invariably done twice, in a mafterly manner, at the cxpence of $6 \mathrm{~s}$. an acre; and I have never feen it done fo well in any other part, except in Suffolk and Effex.

Many things have been fuggefted, to guard againft the attack of the fly, but there is no depen$\mathrm{F}_{2}$ dence 
dence to be placed on any of them $(f)$, the only precaution confints, in ploughing the land till it is very fine, and filling it full of muck. The turnip has alfo another powerful enemy, which is the black canker. Some people draw a rope over the ridges, two perfons holding the oppofite ends; this will bruth them off, and fometimes fave a few acres; but thofe who can breed ducks enow, may fare a greater proportion, as they devour them very faft. There is alfo another remedy, which, I am informed from the beft authority, is practifed in fome parts of Yorkthire; viz. gathering the infect by hand; which is done from 5s. to $8 \mathrm{~s}$. an acre. Women and children being employed in this ufeful bufinefs at $6 \mathrm{~d}$. a day, the women; and the children, at $3 \mathrm{~d}$. and $4 \mathrm{~d}$. each, according to their ages.

Having thus defcribed the culture of turnips, it may not be amifs to add a word refpecting their confumption. In general, they are drawn, and given to neat cattlc, either in cribs or ftalls, which is productive of a vaft quantity of muck; or elfe they are fcattered before them, as well as the fattening flieep, upon a dry piece of pafture or ftubble; and of late years, it is become common, to ftrew them before cattle upon the young wheat, and, upon light land, I believe there can be no better hufbandry; by which means, they go much farther than they would, if trodden into the dirt, 
and enrich the land very much upon which they are fo thrown; it being underfood, in Norfolk, that the land wherein they grow, is left in fufficient heart, by the manure beftured upon it for the turnips: fo that it is apparent, that by manuring one piece of land, they manure two. Indeed, where the land is poor, they draw every other ridge, and feed the other off with theep, as in other counties; but this is not by any means the general practice $(g)$.

The barley, after turnips, is generally fown upon a third ploughing $(h)$, and the grafs feeds with it; and as the ground has been effectually cleaned, by five ploughings, the preceding year, it is generally in a fine ftate when laid down in this manner.

I thall clofe the whole procefs with an obfervation upon the clover:-This, upon the fix courle fhift, is generally mowed for hay the firft year; and the fecond year, it is grazed till midfummer, and then broke up for wheat in fucceffion. Where the four or five-courfe fhift is practifed, the wheat is fown upon one year's lay, and it is thought good hufbandry to muck or afh the clover, in the fpring, juft before it is laid up for mowing, which of courfe produces a very great crop of hay, and leaves the ground in a very high condition, for the fucceeding crop of wheat. 


\section{$\mathcal{N O T} \mathbb{E} \mathbb{S}$}

(a) Upon this fubject, there are three gentlemen who differ from me. Sir Thomas Becvor afferts, that "fhallow plough"ing is in moft cafes difapproved of by judicious farmers, "quotes garden ground, and fuppofes the moifture will be "more preferved the lower the pan lies from the furface."Mr. Howlett admits, that "it may do very well in Effex, "Suffolk, and Norfolk, but thinks, in the deep Kentifh foils, "that thiftles would never be effectually checked by fhallow "ploughings."-Mr. Fox thinks, that "the pabulum imbibed "from the atmofphcre, is proportioned to the depth of the "furrow, becaufe a greater furface of earth is hereby ex"pofed to its influence. Plants alfo thrive beft where "they fhoot with frecdom, and this they do more effectually, "it is fubmitted, when the foil is loofened to a due depth." For trees and plants of deep root, the depth which thefe gentlemen recommend, is unqueltionably proper; but, with defercnce to their opinion, I do not think it neceffary for the production of corn. It is not, however, from mere opinion, that I have advanced this doctrine, but from very extenfive obfervation. - The allufion to gardens will not hold good in this cafe, as the foil there is always kept in motion by the fpade or hoe.

The parts of England, which I have feen, are cleaner, that is, more free from weeds, where the foil is ploughed only to eight inches depth, and a good pan preferved under it, than where it is ploughed to a greater and irregular depth.

In many parts of Cornwall, the land is exceedingly fruitful, where the foil is very thallow, and it may be worth obfervation 
tion, that even hand hoeing often cleans land morc than deep ploughing; for the latter only turns the roots of the weeds over, which gives them freh vigour, by the motion, but the latter more effectually deftroys them, by bleeding them (if I may be allowed the expreffion) at the neck of the root. Another ftrong argument, in my opinion, in favour of fhallow ploughing, or rather, againft very deep ploughing, is, that there is a lefs body of earth to keep in heart and good condition, and the manure, which has always a tendency to eficape downwards, is kept longer near the furface.

(b) The following remark is made by Sir Thomas Beevor. "A quarter of wheat, weighing $60 \mathrm{lb}$. to the bufhel, pro"ducing about $480 \mathrm{lb}$. of white bread, (the only bread the "poor fhould eat) will give about 19 oz. per diem, which is " as little as can well be allowed to each perfon, being almoft " the only food of the poor, and in the houfes of indultry and "prifons the allowance is not lefs than $2 \mathrm{lb}$. and $\mathrm{t} \frac{\mathrm{x}}{2} \mathrm{lb}$. per " diem, $f_{1} x$ bufhels therefore, which will give but about 15 "oz. per diem, it is apprehended, is beneath the quantity "confumed." I bclieve Sir Thomas is quite right, if his remark is applied merely to the labourers in agriculture, allowing them white bread only; but, if the whole of the fuperior, middling, and manufacturing claffes of mankind, who eat plenty of meat, be taken into the calculation; and Itandard, inftead of white bread, be eaten, I do not think that, one with another, more is confumed than $f_{1} x$ bufhels by one perfon in the courfe of a year.

(c) Mr. Howlett fays, "fome perfons in this ncighbourhood, " (meaning Dunmow, in Effex, fo far reverfe this practice, " that they prefer year old wheat to new, and think that they " thereby fecure their crop more effectually from being fmit"ten. This, perhaps, merits further enquiry." This gentleman has totally inifaken my meaning. I do not fay any 
thing about any preference to old or new wheat, but merely recommend the proper feafon for fowing, by taking a hint from nature, inferring, that lefs feed will anfwer the purpofe when the proper feafon is attended to.

(d) Dr. Temple fays, "it ought to be a very good acre, " and of good quality to do this. In the Atalls it may do it."

(ع) Mr. Baillie rays, "many parts, both of England and "Scotland, practice a much better." I wifh for the advantage of Norfolk, that this gentleman had been more particular in pointing out thofe particular parts, and till he does it, I muft doubt the fact; for, if he is right, I have taken a great deal of unneceffary pains in defcribing and holding out the Norfolk fyftem of turnips, as deferving imitation by the reft of Engband.

(f) Lord Rofeberry remarks, that "rolling in the night " has been ufed with fuccefs on turnips, when in their fir?t "leaf."

(5) Sir Thomas Beevor further obferves, that "the beit " farmers, near Norwich, efpecially where the lands are rici "and moift, feed their bullocks chiefly in yards, which have " theds erected in them, under which binns and racks are "placed, whereby the cattle, kept dry and warm, thrive "fafter with lefs food, and with lefs wafte of hay and fodder." In this method I entirely agree with Sir Thomas, and think the cheapeft and bet way of fattening a bullock, is to give him plenty of turnips, in cribs, in an open yard, with plenty of barley or oat ftraw, in a rack under a fhed, where he can take thelter when the weather is bad. A beaft ireated in this way, will do as well, having his liberty with plenty of turnips and ftraw, as he will, confined in a ftall with turnips and hay. 
(ii) To Sir Thomas Beevor's remark on my former edition, in this place, where I had ftated, that the cuftom was to fow barley after turnips, upon two ploughings, it is incumbent on me to acknowledge my miftake, and to allow, that Sir Thomas was right in faying, it fhould be three ploughings, which I have now fated it to be.

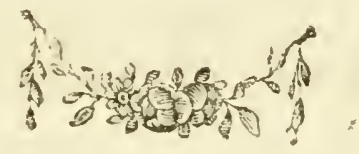




\section{Serevion $X$.}

\section{GRASS LAND-WITH HINTS FOR ITS IMPROVEMENT.}

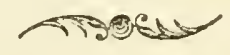

THE meadows, are the fin $\mathrm{n}$ fort of grafs land in the county, which I fhall endeavour to defcribe; they are, in many parts of the county, reckoned much inferior in value to the arable land, and, in general, they are very much neglected.

In their natural fate, they make a bad appear. ance, being fpongy and full of rufhes; yet they are feldom wet in themfelves, but chiefly fo from being dript upon by the fprings which iffue out of the arabie land which lies above them. The beft mode of draining thefe meadows, is to keep the rivulet open to a free difcharge in the loweft parts $(a)$, and to cut two very decp drains, one on each fide, parallel with the rivulet, juft between the arable and meadow land, where the fprings generally fhew themfelves; and thefe two drains, if they are funk deep enough to get below the fprings, will, nine times out of ten, lay the meadows dry. 
The Eflex mode of under-ground draining, from the loofe pulverized ftate of the foil, has not been found to anfwer here fo well, as upon a more cohefive foil, nor is there any other which does fo well for the meadows, as what I here defcribe; but where the plough goes, if the land be wet, or full of fprings, the Efrex mode is beit, and ftones, when they can be met with, are, in fuch cales, to be prefered to wood.

The next thing, if they are very coarfe, is to fpread upon them ten or twelve loads of finall gravel or fand, per acre, which will tend more than any thing to give them firmnefs, fine the furface, and fweeten the herbage, by encouraging what is called the Dutch clover to fpring, with which the earth is evcry where impregnated. I have found, by confiderable experience, that this is the beft improvement for Norfolk meadows. Mr. Marnall recommends watering, and fays it would double theirvalue; Mr. Colhoun, and fome other fpirited gentlemen in the neighbourhood of Thetford, have lately introduced the practice there, to which I wifh molt hearty fuccefs, but am much inclined to doubt its being cxtended to any great bencfit in this county, for I have tried it more than once. It is an improvement that ought to be introduced wherever circumflances are in its favour, but I have not found it anfwer here, for two fubfantial reafons; becaufe the country is fo flat that you cannot 
cannot bring the water on with a fufficient fpirit; and if you could, the foil is fo dead, it would not have the effect it has upon a gravel. It is the firft of all improvements, undoubtedly, where it can be effected, and where the foil is of a quick and lively nature, it generally anfwers, if it be ever lo poor.

The marfh-land comes next under confideration. The greateft part of the hundred of Freebridge Marfh-land may be confidered of this kind. - The chicfeft part of this foil is a rich ooze, evidently a depofit from the fea. The north part of this hundred is highly productive; but the foutis part very much injured, for want of a better drainage, which it is now likely to have, as a recent act of parliament for this, and other purpoles, has been litely obtained.

A fecond divifion of Marfl-land, lies upon the north coaft, between Brancafter and Cley. Thefe are of a very good quality; but they are kept embanked at a very confiderable expence, for if the fea were to overflow them, they would be ruined for a very confiderable time.

Another very confiderable diftrict of marfh-land, lies between Norwich and Yarmouth; molt of which are under water the greaten part of the winter, and, in the fpring of the year, are chiefly drained by mills. 
All thefe marfhes are capable of bringing a beaft very forward, in the courfe of the fummer, and many of them will fat a bullock at the rate of an acre and an half.

There are many large tracts of fwampy ground, particularly in the neighbourhood of Ludham, which produce little more at prefent than fedge and reed. Perhaps the intermixed flate of thefe lands may be the principal caufe of their drainage being neglected; but their lofs to the public is very much to be lamented, as there is no doubt but they would very well anfwer the expence of improvement.

A fhort obfervation upon gentlemens' parks may not be improper in this place.-In many parts, they are inclined to run to mofs, as the foil in general is not naturally adapted to herbage.Folding fheep, or ftrewing turnips before neat cattle is a great and obvious improvement upon fuch land; and occafional harrowing, and frequent rolling, is likewife much to be recommended. The former loofens the mofs, and the latter, by its preffure, gives great encouragement and affítance to the annual meadow and crefled dog-tail, two of our beft upland grafles.

A certain number of fheep fhould likcivife be kept, at lean part of the ycar, in all parks, notwithflanding 
withfanding deer are kept likewife; for no animal tends fo much to the bettering of land, as they fine and fweeten it infinitely beyond any other.

Artificial graffes fhould be chofen agreeably to the foil.

Saint foin, fhould be introduced where there is a chalky, marly, or even a gravelly bottom.White clover fhould be the principal grafs where land is defigned to be laid for a continuance.Trefoil and burnet, upon high and poor uplands, defigned for theep walks.-Perennial darnel, or what the farmers call rye-grafs, is proper upon light arable land; for though it is an exhaufter, it ferves better than any other to brace the furface.-A few acres of lucerne I likewife recommend to every farmer, who has a piece of loamy tillage near his houle. 


\section{$\mathcal{N} O \mathbb{T} \mathbb{E}$.}

(a) Sir Thomas Becvor fays-" Thefe directions are moft " judicious, and have, on long and repeated expericnce, been " found efficacious."

(b) Dr. Temple is for laying on a much larger quantity, and fays, "60, 80 , nay 100 loads of fand will be found nece?. " fary, after drainage, to effect a cure for fuch land, and to "s make it firm and fruitful." The Dr. in my opinion, would much over do the thing-though, if the expence be out of the queftion, I have no objection to twenty loads. It is not fo much for adding depth to the foil, as for giving encouragcment to the white clover, by checking the rougher herbagc on the furface, which chokes and overpowers it. Sir Thomas Beevor conceives my meaning much better, where he fays, "Such quantity may fo far invigorate the Dutch clover " (the plants of which, though exifting before, were fo dimi": nutive as to have efcaped obfervation) as to render it con"f fpicuous; which is, I conccive, what the author of this " view meant, when he fays-that the carth is erery where "s impregnated with it." 


\section{商ection XI.}

\section{AVERAGE CROPS, AND SCALE OF RENT.}

THERE are fome parts of Marfhland and the Flegg hundreds, which will produce fix quarters of wheat, and ten of oats, upon an acre; but, in very light parts of the county, the farmer is glad to get two quarters of wheat, and three of barley. However, I believe the general average crops of the whole county, one year with another, may be eftimated as high as three quarters of wheat and four of barley, and other articles in proportion $(a)$.

In fome parts of Marfhland, therc is a confiderable deal of rape feed grown: in the parifhes of Outwell, Upwell, Emneth, and fome others in the neighbourhood of Wibeach, there is likewife a confiderable deal of hernp and flax fown. The average produce of the former is about forty-five ftone, and the latter abcut forty, which are valuable crops. Thefe articles are of national importance, and if properly confidered, no injury to she land; 
for when they are cautioufly interwoven with other crops, fo as not to come round above once in ten or twelve years, it would be well if the cultivation of them were more general.

No population can be greater, or of a more ufeful fort, than that which is raifed and fupported by a country, where this practice prevails; as may be proved, by reference to many parts of Somerfetfhire, Dorlethire, and Yorkfhire, where it occafions fo much profitable labour, that no perfon, in fuch a fituation, wants employ.

Rcfpecting the fcale of rent, it is the moft diffcult queftion to anfwer, with precifion, of any the Board requires; for there is nothing fo unequal in the kingdom, as the rent of land. Corn, and all articles of merchandize, preferve fome degree of proportion; but the price of land, is fo much affected by local circumftances, that it has no regular ftandard, though it would be a great advantage to agriculture if it had. Perfons of fmall fortune, and tradefmen, when poffeffed of a little land, arc naturally induced to get as much as poffible for it; and farmers, above all others, when they become owners, make the wortt landlords in the kingdom $(b)$. It is therefore to large eftates, that we are to look for moderation in rents $(c)$, as they are generally let upon a fair and confiftent licale. From this confideration, more than any 
other, great efates are of advantage to the public, as they have a tendency to keep the price of land down to a proper level, which otherwife would, in many places, become fo exceflive, as to give no encouragement to an induftrious occupier.

As to the general ftandard however, of rents in this county, fubject to poor rates and tythes, I believe it varies from 20 s. to $16 \mathrm{~s}$. an acre, in the firft divifion of the county, which I have defcribed; from $18 \mathrm{~s}$. to $14 \mathrm{~s}$. in the fecond; from $14 \mathrm{~s}$. to $8 \mathrm{~s}$. in the third; from $12 \mathrm{~s}$. to $4 \mathrm{~s}$. in the fourth; and, in the Marfhland hundred, from 30 s. to 20s. The aveage of the whole county is about $I_{5}$ s.; and though this would be a dear rent, for the fame foil, in moft other counties, the nature of the hufbandry, and the induftry of the inhabitants, render it eafy, and rents are better paid in this county, than in almoft any other, as there is hardly any fuch thing as an arrear known; at the fame time, the farmers live, as they are entitled to do, with comfort. 


\section{$\mathbb{N O \mathbb { T }} \mathbb{E}$.}

(a) Sir Thomas Beevor fays, "the average of the wheat "crop is certainly fet too high, as there is a great deal of "land, in this county, fown with wheat, which is too light "and poor to produce above 12 or 14 bufhels per acre; it is "s apprehended, that $2 \frac{1}{2}$ quarters, per acre, is rather above "than under the general average of the whole county." I cannot, however, alter my opinion upon this, as I have taken great pains in comparing the quantity of good and bad land; from which, I have formed my idea of this average.

(b) Mr. Baillic remarks in this place, "this is very true."

(c) Mr. Howlett fays, "this feems a far-fetched recommen"dation of large farms, and which they by no means fand in s: need of: Large farms are managed at a much fmaller pro"s portional expence, and raife a larger proportional produce. "The conclufions are obvious." Mr. Howlett muft allow me to fay, that I had not the leaft idea of great farms. I cannot fec upon what grounds of confiftency $\mathrm{Mr}$. Howlett could fuppofe, I meant to compliment large farms on this occafion-I meant large eftates, and it furely is clearly expreffed fo. As to the larger proportional produce, and the other advantages, which he defcribes to large farms, they are not fo obvious to me, as to him. 


\section{Section XII.}

\section{IRREGULAR CROPS.}

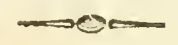

\section{IHOUGH it is highly proper to confine tenants to a regular fyftem of cropping, yet there are forne little variations, that under certain circumflances, they ought occafionally to be indulged in.}

When, for inflance, a piece of land is well cleaned, mucked, and fown with turnips, and the crop, notwithftanding all poffible care, does not fucceed; in fuch cafe, if the tenant be allowed to fow wheat $(a)$, and, in the enfuing fpring, clover among it, no harm can refult from it, as it would have been feeded with barley if they had fucceeded.

No landlord ought to object to this, as the land is neither injured, or ultimately put out of courfe by it; at the fame time that the difference in value, between a wheat and a barley crop, will be a full compenfation for the inconvenience the tenant fuftains, by the lofs of his crop of turnips. 
Sometimes it will happen, that grafs feeds will not take root. In fuch cafe, it would be a hardfhip to confine a tenant to keep that piece of land in an unproductive ftate for two years: he fhould, when this happens, be allowed to take a crofs crop, being confined to turnip or vetch it, after fuch extra crops.

The vetch is a moft excellent thing; and great advantage may be derived from it, in various fhapes. If a piece of barley or wheat ftubble, which comes in courfe for turnips, be found tolerably clean and mellow after harveft, it is a good practice to fow vetches upon it, and harrow them in, as foon as the corn is off. They will often produce a great deal of valuable feed for ewes and lambs in the fpring, when fuch kind of affifance is of ineftimable worth, and yet admit of the land being got into very good order for turnips. They are likewife of the greateft profit when cut green, in the courfe of the fummer, and given to cows and working horfes, in the ftable. An acre, cut and ufed in this way, will go farther, and do the horfes more good, than two acres eaten off in the field: working horfes want reft; in the ftable they are not teafed by flies; befides, the quantity of muck which horfes make, fo foddered, is prodigious. 
Exclufive of thefe helps from the vetch, a few acres of potatoes, and the drum-headed cabbage, are greatly worth a farmer's attention; for they are excellent foud for milch cows, and anfwer well, and ought to be cultivated much more than they are, as there is but a very finall quantity planted in this county. Carrots are likewife of great value to a farmer, and ought to be grown in greater plenty than they are. A few acres of lucerne, when a good plant can be got, and it be kept clean, is likewife a wonderful help.

Buck-wheat claffes, more than any thing, with the irregular crops; though it is not fown fo often as it was formerly. When it is fown, it is moftly introduced after the barley that follows the wheat, and is frequently fucceeded by wheat; but this is reckoned bad hurbandry, and ought not to be allowed, unlefs it be ploughed under for manure, or unlefs the wheat flubble which follows it, be turniped.- The beft mode of introducing it, is after wheat, inflead of barley, when it may be houfed as a crop, and then to turnip the buck fubble. This laft is good hufbandry, as it does no fort of harm to the land, and is an excellent foremnner to turnips, which generally grow kindly after it, and, this way, the land is not at all put out of courfe.

Peafe are generally fown upon land coming on for a fecond year's lay; beans and hops are but little 
little cultivated; cabbage, for cattle, is but feldom planted; orchards very few, and much neglectedconfequently' no cyder.

But above all, where land has a chalk or marl at the bottom, let not faint-foin be forgotten (b) upon fuch a foil as this; or even where there is gravel under a good furface, it is impoffible to fay too much in its favour. In this country it is but little known; I believe the firft perfon who brought it into Norfolk, was the late Sir Henry L'Eftrange; next to him it was countenanced by Mr. Rolfe and the Rev. Armine Styleman; but the greateft planter of it is Mr. Coke, who has, this dry fummer, cut two hundred and fixty-five loads of excellent hay, rather exceeding a ton to a load, from one hundred and four acres. This was from a plant of four years old, upon land not worth more, for any other purpofe, than twelve fhillings an acre. He is fo convinced of its great utility, that he has lately laid down an hundred acres more, and has it in contemplation to carry the cultivation fill further.

Next to advifing the planting all land, that will kear it, with faint-foin, and the flooding of all mcadows, where waicr can be got over, as hay is at all times an article of the greaten value to a farmer, and what almoll every country is crying out for, if a winter is at any time fevere, I molt urgently re- 
commend to all farmers, to be more careful of it, than they generally are. It is not uncommon to fee a fourth or a fifth part of it wafted in the confumption, by being given to cattle in too great quantities at a time, and in a loofe, fovenly manner. Racks, with clole bars, thould be obferved for horfes; and deep cribs for oxen. Sheep are ftill more apt to create wafte; therefore the cutting of hay, in like manner as fraw is cut, into chaff, is a frugal and excellent practice; for by this means, there is no wafte at all : and it is certain, that hay given in this way, will go confiderably farther, than if given in the old way. It may allo, by this means, be often, with great propriety, mixed for oxen or horfes, with a fnall proportion of ftraw.

I am fo thoroughly convinced of the advantage attending this mode of confumption, that I fhall fteadily adhere to it, wherever my authority or influence extends. - The ufual price for cutting in this county, is $3 \mathrm{~d}$. for four heaped bufhels, and a man, who is expert at it, will earn 3 s. $6 \mathrm{~d}$. a day. 


\section{$\mathbb{N O T E S . ~}$}

(a) Sir Thomas Beevor fays, "If this be allowed, the land "Thould lay two years in grafs, otherwife the fucceffion of or wheat will be too quick, but if on a ftrong foil, he re" commends a crop of beans."

Sir Thomas Becvor is perfectly right in faying it fhould by two years after wheat-fuch is my meaning too; but beans will not do, becaufe in that cafe the grafs-feeds could not be fown.

(b) Mr. Dan very ably feconds my recommendation in this place by the following remark- "I have cultivated faint-foin " extenfively, and on a thin foil, with a chalk and gravelly "bottom, many years; and do not know any thing that can "be cultivated more advantageoully on fuch a foil.". 


\section{Section XIII.}

\section{FALLOWING EXPLODED.}

\section{सP:}

I $T$ is a queftion with fome perfons, whether fum. mer fallowing be necellary or not? I am one of thofe who do not think it is. Nature does not feem to require any paufe or reft of this kind; all plants make their annual hoots, as regularly as the day fucceeds the night. The earth was evidently defigned to yield a regular uninterrupted produce; and it does fo, where we leave it to itfelf. If you do not fow corn it will produce weeds: its productive quality never ceafes. It is therefore our bufinefs, by good culture, to expel the unprofitable plant, and introduce another, from which we may derive benefit. The idea of leaving land to reft is ridiculous; keep it clean, and intermix the crops forn upon it judicioully, fo that one may fertilize as much as another exhaufts $(a)$; and it may be lown as a garden is planted, from one generation to another $(b)$. Look at half the common fields in England, where the fyltem entablifhed by the old fchool is called two crops and a fallow. 
What does this exhibit, but a conflict between the farmer and his weeds, in which the latter generally get the better; for they are only half ftifled, and never effectually killed?

On the other hand, vicw this county, which yields a crop every year, without being exhaufted $(c)$; and though the foil in many parts is light and ordinary, by being kept clean, feldom fails of a fair return, which enables the farmer to employ more hands, and give a better rent $(d)$; which are two important conficerations, the one being beneficial to the country at large, the other to the landowner.

This fubject fecms to have excited fome doubt and objection, as will be feen by fome of the comments annexed. I do not, howerer, fee any reafonable ground for the fupport of fallowing. The Auftrian Netherlands, one of the moft productive diftricts in Europe, allows of no fuch ufelefs interruption in the rotation of its annual crops, nor does this ccunty, which is the neareft copy to it of any part of England. The turnip crop, in fact, is here the fallow, and certainly brings land into a cleaner flate than any other mode of cultivation.

Thofe who talk of refling land, feem to confider it in the nature of an animal, which undoubtedly mult have reft as well as food, to go through la- 
bour; but furely this does not hold good when applied to the nature of land, which, by proper attention, will be found grateful and productive without ceafing.

I apprehend, the cuftom of fallowing, originated from the ancient ftate of the common fields, before the intruduction of turnips and artificial graffes; in this early period of our hufbandry, fallowing was abfolutely neceffary, as there was but little flock then kept in proportion to what there now is, therefore land could not be fo often or fo well manured as now; with the inclofure, therefore, of common fields, fallowing cught to have ceafed, in other parts as well as here; but where farmers fill continue the reprehenfible practice of takıng three crops in fucceffion, which is fill the cafe in many parts of England, there fallowing is abfolutely neceffary; but it is by no means a neceffary part of Norfolk hufbandry. 


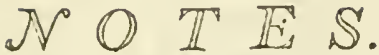

(a) Mr. Baillie remarks, "t this is the only thing wanted"but I fuppofe Mr. Kent means that the fertilizing crop is to ss pals through the body of fome animals, to convert it into " manure, and not that a crop growing upon land will ferti"lize it." My meaning is plain, that a crop of turnips, yetches or even clover, either fed off upon the ground where grown, or confumed in the ftables, ftalls and yards, will add as much benefit to the foil, as the wheat and barley crop will injure it.

(b) Mr. Howlett fays, "s all this fpecious thcoretical rea" foning feems to be fufficiently refuted, by an appeal to fact " and experience, made in the Effex Survey, page 16.

a Indeed, the expediency of fallowing, or not, muft de"pend partly upon the nature of the foil, and partly upon " the quantity of manure that can be raifed."

What grounds Mr. Howlett can have, for calling this mere fpecious and theoretical reafoning I know not, and as to the expediency which he alludes to, I truft I have fufficiently explained that at the latter end of this fection; but $I$ with he would attend to the next commentator but one.

(c) Mr. Baillie has another remark to the following effect, "This cannot be fairly faid, becaufe it has heen complained "of, that it does not produce turnips fo well now as for" merly, \&c. The greateft defeet of the Norfolk fyltem "feems to be in ploughing too much, and of not kceping of "more Theep, and of a better kind." With fubmiffion, I 
think, that too much ftrefs is here laid upon what I faid about the land not being fo kind for turnips as formerly; fo far it is a fact, but this did not mcan to imply, that good turnips were not ftill grown; all that was meant was, that more care and attention was required; bat, notwithftanding the inconvenience I allude to, I may boldly fay, that I have never feen fo good turnips, or fo many acres of them, in any other county, as are ftill grown in Norfolk.

As to faying it is a dcfect in the Norfolk fyftem by ploughing too much. How can that be? when there is only half the arable land in corn and grain, at any one time, cither under the frx-courfe or the four-courfe fhift.

Refpecting cattle, I know no country, of a fimilar foil, where fo much are kept; and as to the theep, Mr. Baillie muft excufe me, if I do not give him credit for being a proper judge of what are the beft fort of fhecp for this county.

(d) Mr. James obferves, that-" The perufal of the firft two "paragraphs has afforded me great fatisfaction. The necef" fity of fummer fallowing is at laft called into queftion, and "I have no doubt, if we could overcome people's prejudices, " (which, by the bye, is more difficult to deftroy than the "wceds) this practice would be entirely exploded -I conas ceive, the intention of them is not fo much to afford the " earth that paufe or reft, on which our author has fo inge"G nioufly and fo very reafonably remarked, as by furnifhing " the farmer with an opportunity of expofing the roots of the " weeds to the rays of the fun, by repeated ploughings, in " order to effect their deftruction. But lct me afk, by way of "expofing the fallacy of this method of fallowing, how would "t this deftruction be effected in the cafe of a dripping fummer? "And would it not be very unfortunate for that perfon who " was under the obligation, by the articles of his leafe, or lis "e unconquerable prejudice, to fallow in fuch a feafon? Woulc? 
" he not loie a year's rent of that part of his farm, without $\because$ being one jot the forwarder, with the addition of a con" fiderable expence, incurred by a great proportion of la"bour, into the bargain? Surely this, if properly confi"dered, proves, inconteftibly, the fyftem to be founded "upon wrong principles, and ought to induce us to receive " any opinion, advanced with a corrective motive, as wor" thy our confideration at leaft, and by no means a fit ob" ject of our indifference, not to fay contempt. The Society "for the Promotion of Arts, have taken great pains upon "s this fubject; they are actuated in this, as in every other "ineafure, by genuine philanthropy, and are anxious to be "the means of faving the tenant, or land-holder, one rent in "three. The method which I wifh to recommend is, alter"sately to grow meliorating and exhaufting crops, and to be "careful, in the progrefs of their growth, to hoe them occa"fionally. The drill-hußbandry, wherever it can be ap"plied, ought, on this account, never to be neglected, and " confcquently, the broad-caft hufbandry, for the fame rea"fon, fhould be abolifhed, excepting for turnips and the " finaller feeds: in fact, any method, and of which there are " many extant, is to be preferred to this. It is a trite obfer"sation, that the cleaner any land is kept, the lefs care is "requifite to continue it fo; and I am clearly of opinion, " if the crops are well preferved from weeds in their in"fancy, when they are in the moft danger, and the hocing "continued as long as can be conveniently with their fafety, "the produce will be increafed, and by the weeds being era"dicated (for the bare cutting off their tops will not be fuffi" cient) their feeding will be prevented, as well as their pro"pagation from the roots; from hence I infer, the neceffity " of fummer fallowing may be fuperceded."

This gentleman is a fair, liberal, manly commentator, open to conviction, and, apsarently, grided by no other motise, than that of promoting improvement. 


\section{Section XIV.}

\section{COMMON FIELDS \& INCLOSURES.}

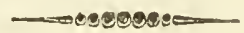

T HERE is fill a confiderable deal of commonfield land in Norfolk, though a much lefs proportion than in many other counties; for, notwithftanding common rights, for great cattle, exift in all of them, and even theep-walk privileges in many, yet the natural induftry of the people is fuch, that wherever a perfon can get four or five acres together, he plants a white-thorn hedge round it, and fets an oak at every rod diftance, which is confented to by a kind of general courtefy from one neighbour to another.

It has long been a fubject of infinite conjecture, how the land of different eftates became originally fo fcattered and divided in common fields. Lord Chief Juftice Coke, in his Reports, fays, "The policy of old times, in feveralling of "fields in fmall parcels, to fo many different per"fons, was to avoid inclofure, and to maintain "tillage." 
Many other reafons are affigned. But, waving all ulelets inveltigation of this fort, I fhall briefly confider the difadvantages that land, of this defcription, is at prefent lubject to, and endeavour to hew the advantages that would refult from laying it more together.

Iand, when very much divided, occafions conifderable lois of time to the occupier, in going over a great deal of ufelefs fpace, in keeping a communication with the different picces. As it lies generally in long narrow flips, it is but feldom. it can receive any benefit from crofs ploughing and harrowing, therefore it cannot be kept fo clean; but what is ftill worfe, there can be but little variety obferved in the fyftem of cropping; becaufe the right which every parilhioner has of commonage over the field, a great part of the year, prevents the fowing of turnips, clover, or other grafs feeds, and confequently cramps a farmer in the ftock which he would otherwife keep. On the contrary, when land is inclofed, fo as to admit of fowing turnips and feeds, which have an improving and ineliorating tendency, the fame foil will, in the courfe of a few years, make nearly double the return it did before, to fay nothing of the wonderful improvements which fometimes refult from a loam or clay; which will, when well laid down, often becone of twice the permanent value in pafiure, that ever it: would as ploughed ground. Moft firiking eflects 
of this fort are to be feen in Leicefterfhirc, Northamptonthire, and other midland counties. This, indeed, has been urged by fome as an argument againt inclofing, as they would infer that it leffens the quantity of arable land too much, and tends to make corn dear; but the excels of grazing and ploughing will correct itfelf. If arabte land be laid down, there is a great deal of coarfe old patture land which may be broken up, the turf of which wants renewing; and this old grafs land, which could not fo well have been fpared before, is, of all land, that which is moft adapted to the growth of potatoes, hops, hemp, and flax. The markets will ever regulate the proportion of arable and grafs land, better than any fixed plan that can be fuggefted.

If we properly confider the benefits refulting to population from inclofing, (though that, as well as the advantages which might be derived from commons, has been fuperficially queftioned) it will frike us with aftonifhment (a). Let the population of England be compared with what it was fifty years fince, and I prefume it will be found increafed nearly a third. If I were afked the caufe, I fhould fay, that I believe it is chiefly from inclofing; and my reafoms for it are, that in all places where my obfervation has come, it carries full proof. I have feen the effects in many parts of England; but I thall fubjoin one ftriking inftance, in this county. The parifh of Felbrigg, belonging to Mr. Wind- 
ham, Member for Norwich, confifts of about 1300 acres of land, and till the year 1771, remained time out of mind in the following ftate: 400 acres of inclofed; 100 of wood land; 400 of common field; and 400 of common or heath. By authentic regifters, at different periods, it appeared, that the number of fouls had never been known to exceed 124, which was the number in 1745; in 1777. they were only 121 ; at this time they amount to 174. This rapid increafe I attribute chiefly to the recent improvements made in the parifh, by inclofing all the common field land, and by converting moft of the common into arable land and plantations. The parifh has no particular connection with any other, and therefore its own increafe of labour and produce muft be the principal caufe at leaft of this ftriking alteration. The parifh of Weyburn, which remains uninclofed in this neighbourhood, belonging to Lord Walpole, who poffeffes, in a very eminent degree, the three great characteriftics of a country gentleman, a good magiftrate, a good neighbour, and a good landlord, is the moft like what Felbrigg was before its inclofure, confifing of about the fame quantity of common and common fields; but I do not find that the population there has increafed of late, which is a corroborating proof of inclofures being in favour of population.

If then, inclofing be found fo beneficial, every obftruction to it ought to be removed. In the $\mathrm{K} 2$ firft 
firft place, were there one general act of parliament formed, under which any parifh that could agree in itfelf, could be able to take fhelter, or even any two or more perfons, agreeing upon any cxchange of land, or a feparation of a mixed intereft, whereby the inclofing of fuch land was the refult, upon paying a fmall confideration, to receive the fanction of a fhort fummary law to bind their agreement. This would infenfibly lead to a vaft field of improvement (b). Something of this fort was lately attempted, but not carried through, and perhaps there might be fomething exceptionable in the plan. It is, however, to be wifhed, that fome member of the Houfe of Commons would confider the magnitude and importance of the object, and bring it forward again. If fuch an attempt be made, upon found and rational principles, I flatter myfelf, the prefent Minifter would not be againft its introduction; nor, I truft, at a lofs, to find the means of removing one of the principal objections to the prefent mode of inclofing, namely, the great expence, when a bill is folicited, which always operates as a powerful difcouragement to undertakings of this kind, and fometimes fets them wholly afide; efpecially, as the fees are double, if another parifh has the fmalleft fhare in the emoluments, though the trouble to thofe who pafs the $a$ at is not doubled by it. But this is not all the difcouragement (c), for in the courfe of obtaining the bill, the evidence mult go up to town, and attend 
attend a committee of the Commons, afterwards be fworn at the bar of the Lords, and attend their committee alfo: and as thefe attendances are often at intervals confiderably difant from each other, the evidence muft all this time either be fupported in town, at a great expence, or make three or four journies; and as this fort of evidence is gencrally given by profeffional men whofe time is valuable, thefe delays are very inconvenient, and frequently operate fo powerfully upon the minds of people, that many an inclofure is paffed over which would otherwife be effected. This in a great meafure will account for fo many of our commons and common fields having remained fo long in their prefent ftate. In making thefe remarks, it is not my meaning to caft reflections upon any quarter, but to awaken the attention of the Legiflature and the Board of Agriculture to the importance of the fubject, that all poffible encouragement may be given to the honeft enterprife of individuals; for all improvements in Agriculture, which carry great weight, and ine the end become national objects, muft be effected by the individual, becaufe it muth be the multitude that cultivate the hidden corners of the earth, and "out of a little make a mickle". Any thing which Government could do in a pecuniary way, by cncouraging a few perfons in a local fituation, will nerer operate fo extenfively as the natural cxertions of the public: doubtiefs Government will give the individual at the affifance it 
can, to remove vexatious obftructions, and fmooth the road to honeft undertakings which individuals may wifh to bring forward. It is likewife prefumed, that it will be found policy in Government fo to do, as it will ever derive a proportionate advantage from the induftry of the people. I trult, therefore, that the Legillature will fee the neceflity of contriving a lefs expenfive mode of fanctioning inclofures in general, for the good of mankind, as well as its own emolument.

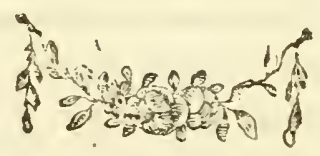




\section{NOTES.}

(a) Mr. Wagftaff obferves, that " an increafed population, " in confequence of inclofures, is happily here illuftrated, and "s it might be pertinently added, that fuch lands, fub-divided or into farms, from 40 to 100 acres, would, in as certain a "r ratio, increale the number of inhabitants, as the cultivators " of 1000 acres, inclofed from the wafte, do increafe the "number of the local refidents, when in the hands of one or "two occupiers only, while the fum of the gains, on this "divifion of occupations, will probably be equal in tiventy "families as the one or two, and the fum of their produce " augmented; while farms, too large, are frequently the in" Atruments of luxury to their polfeffors and their pofterity, " and what is really to be deplored, the caufe of emigration "s of many capable agriculturifts, whofe difpofition and habit "s would be indulged by a fettlement at home. Under favous " of the Board, by a line of permiftion from its Prefident, I "conceive I can lay before them, practical means for the "s conftitutional redrefs of the aforementioned grievances, at : leaft leffen their evil, and, in their whole tendency, bc in"dividually, focially, and nationally beneficial.

(b) The following fenfible and manly remark, is from Lord Rofeberry. "Such an act, and fuch a plan, would be the " greateft bleiting England cver met with, and by fuch a "general aft for inclofing and dividing commons and com"monable lands, at fmall expence, parliament would do more "for agriculture and population, than ever was done before."

And Mr. Strachey wilkes to fee a fimilar "aft for making "turnpike roads, where a majority of perfons, polfelling a "certain property, agrec amongft themfelves. An act of a "moderate length now co!ts 2001 . which is a great difcourage"ment. The fees to the clerks of the Houle of Commons, 
" and Houfe of Lords, are confiderable; but upon the paffing - fuch an act, for the public convenience and honour of the " country, either Houfe might contrive a compenfation to " thofe, who would be deprived of the emoluments which " now arife to them, from the turnpike bills annually brought " in."

(c) Mr. Jancs remarks thus:- "What is here hinted at " as the molt powerful difcouragement to undertakings of this " kind, nameiy, the enormous expences which are incurred, "I am of opinion, would entirely fubvert the excellent me" thod he has fuggefted, was it ever to be propofed; for the "perfons benefited by thefe expences, are not quite fo difin"ierefted a fet of men, as to relinquifh them without oppo" fition, and there is no doubt but here they would, in all " probability, be but too fuccefsful. If the Minifter were to " introduce a bill, whore object went to the total abolition, " of not only particular, but fees in general, a number of "improvements would prefently be the confequence, which "would not be confined to agriculture."

Mir. Howlett is likewife a commentator upon this fection, and admits, that what $I$ fay about the excers of grazing and ploughing correcting itfelf " is undoubtedly juft and conclu"Iive; but where I fuppofe the population to be increafed " nearly a third within the laft fifty years, which, by the "way, was merely a fuppofition, he believes it to be above "the fact, and that the increafe, fince the Revolution, is little, "if any thing, above one third, though the greatelt part " of the increafe has taken place during the laft fifty years, " that this has been occafioned, in fome fmall degree, by in"clofures.-The tendency to increafe population, he fays, " he has fully eftablifhed upon much better, more extenfive, " and fatisfactory evidence, than is here produced-and that " he has much more evicience of a fimilar lind now by him." I hope this additional evidence will foon come out, and that it will be as fatisfactory to the public, as it is to himfelf. 


\section{乌ection XV.}

\section{THE COMMONS CONSIDERED.}

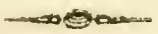

$\mathrm{T}$ very different in their quality. Thofe in the neighbourhood of Wymondham and Attleborough, are equal to the fineft land in the county, worth, at leaft, twenty fhillings an acre; being capable of making either good pafture, or producing corn, hemp, or flax. There are other parts which partake of a wet nature, and fome of a furze and heathy quality; but they are molt of them worth improving, and all of them capable of producing fomething: and it is a lamentable thing, that thofe large tracts of land hould be fuffered to remain in their prefent unprofitable ftate. The arguments for the continuance of commons in their prefent fate are, in general, fallacious; and though fpecious, are grounded on miftaken principles of humanity. The advantage they would be to fociety, if properly cultivated, would be very great, and L. the 
the attention of the new Board will, I truft, foon be fixed upon this important object, fo as to find the means of removing the great impediments which prevent their inclofure, upon which I have made a further obfervation under the head of common ficlds.

After making a fair deduction for roads, there are fuppofed to be fomewhat more than eighty thuufand acres.

From obfervation and enquiry, I find, that in the mon fertile parts of England, the people employed in agriculture, and the rural trades connected with it, are in about the proportion of one to fix acres; and if a proportionate number be added for the towns, and people employed in other trades, not connected with hufbandry, the number will be, perhaps, as one to four acres of land. But as the more ordinary parts will not carry fo high a population, the fafer average may be to fet the fale generally, as one to five acres; and as thefe lands do not fupport a third of the number of people which they would do, if they were cultivated; however, fuppofing they do, at this time, fupport a third of what they would do if improved, ftill there is an apparent lofs of 10,666 perfons, in this county only, which being highly agricultural, with a large proportion of manufactories and trade, I thall leave 
the benefits which would refult from the inclofure of this great tract of land, to the entimation of the financier $(a)$.

And why fhould not this rude tract of land be cultivated? Why fhould this rough jewel remain unpolihed?

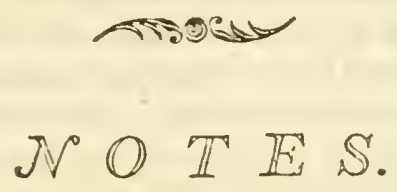

(a) Mr. James remarks thus:- "The advantages the public " muft derive, from a proper cultivation of all the wafte lands "and commons through the kingdom, fecm to be obvious to " every one who is devoid of prejudice. The principal, indeed, "the only impediment, which has any weight with me, upon "this fubject, is the encroachment it may occafion upon the "rights and privileges of the poor, and, if they are deprived "of them in one way, the difficulty of afccrtaining what they " are precifely, and of providing them with an equivalent. "Some have propofed doing this by allotting a piece of land " to cvery cottage, but this method, at firft fight, muft ap"pear objectionable, as this addition becoming the property " of the perfon to whom the cottage already belongs, the "benefit will not extend beyond its prefent tenant, and "property will not remain with him for any length of time, " as it may prove a temptation to his landlord to advance his "rent, and in a proportion inconfiftent with the advantages " he may derive from it. Others have thrown out an idea of "purchaling the wafte lands from their refpective parifies, "s and eftablifhing a fund for the benefit of the poor, and I. 2

"thore 
" thofe claftes who come under our confideration. This me"thod I have feveral objections to; namely, that it is more " likely to relieve thofe on whom the poor's rate are at pre" Sent levied, rather than prove itfelf that fair and equitable "equivalent, without which, this important reformation can"6 not in honour be undertaken-but my principal one is, that " of fubftituting money as this equivalent. It ought to be an " object of our confideration, in this momentous bufinels, that "the value of the exchange thould be permanent, and, if "money is to be the exchange, how can this be faid to be the "cafe. In proof of this, how much the labouring poor of "this country would have fuffered, if this circumftance had "taken place in the laft century, if money had been equiva"lent, when it is fo well known, how much alteration has "taken place in its value, while every neceffary article of "life is more than doubled."

Mr. Wagftaff fays, "perhaps there are certain tracts of " land, neceffary ranges for combined flocks, belonging to of fmall proprietors, whereby the fleece is improved: but "s there is this misfortune attendant on rich commons (and "fuch are what this gentleman truly remarks of Wymondham or and Attleborough) through each claimant on them making "s the moft of the prefent advantages, without adverting to a "6 wanted improvement that might continue and fecure, in the "future, an addition of advantages; through this defect, of "6 what is every claimant's bufinefs, fuch as undrained waters, " which contaminate where they continue, and is, I am per" fuaded, an addition to the too lengthened continuance of 6: their ranging, the origin of the decay, which, fometimes, "becomes contagious to other theep; and this, I prefume, of arifing for want of a compulfory tax, to oblige the feveral "claimants to improve their common privilege, by requifite "drainage, ditching, embankment, and elevation of low "ground, to which might be added, the omiffion of fummer " mowings of the immenfity of thiftles and ragweed: as by o thefe attentions, the falubrity and certainty of an excellent 
"pafturage might be perpetuated; then, under thefe circumof ftances, perhaps, they may not admit of much more im"provement. But very different are the commons of a "furze and heath production; nothing fhort of cultivation, "can make them properly productive. But, as I have taken " the liberty to addrefs the Board, on commons of this de" fcription, I mult beg to refer them to what I have already s faid, and what I propofe farther to fay, in another addrefs "s to them refpecting Mofwold. I feel an ardent wifh to " fee the extended wafte Mofwold cultivated, (which is "partly within the boundary of this city) and which is like" wife a part of fifteen country parifhes. I was thinking that " in inclofing it, that it might be a fubject of policy, as well " as juftice, to appropriate for the cottage poor, folely, a "common, from thirty to forty acres, to each parifh; this "would be a facrifice that might befpeak their acquiefcence, " and appeafe a poffible difpofition to turbulence. Thefe "conceffions, I conceive, would not be a twentieth part of st the whole; perhaps what is in the precincts of Norwich, " may have a rental referved for an annual diftribution to its "poor inhabitants."

This interefting fubject of commons, is much indebted to the two gentlemen, whofe obfervations I have here inferted; the humanity and good policy of their tendency, are equally to be admired, and I make no doubt, but fome material advantage will be derived from their ufeful hints. 


\section{Section XVI.}

\section{WOODS AND PLANTATIONS.}

IN my firft report, I flated, that the woodland, of an old ftanding, was not confiderable; that a fingle wood, or coppice, was found here and there, but no great tract together; and that the county was not remarkable, for any particular application of the underwood, further than the mere purpofe of theep hurdles and materials for thatching. At that time, I confldered Foxley wood, which is three hundred and nine acres, belonging to Sir John Lombe, Bart. as the largeft in the county, which I ftill believe to be the cafe; but I have fince learnt from Sir Thomas Beevor, that there are feveral other confiderable woods in Afhwell Thorpe, Hetherfet, Ketteringham, Hethel, Bunwell, Hempnall, and Shottifham, of eight hundred or a thoufand acres, in the aggregate, befides feveral other fmaller woods in other parts, and that the underwood is ufed for hoops, as well as thatching, and other purpofes of repairs. 
The modern plantations, fuch as relate to the mere embellifhment of gentlemen's feats, have kept pace in this county with mol other parts of England. Great bodies of firs, intermixed with a lefs number of foreft-trees, have been planted, by moft of the gentlemen of large fortune, in their parks and home grounds; but the planting of pits, angles, and great fcreens, upon the diftant parts of their eftates, which I conceive to be a greater object of improvement, has been but little attended to. I fhall mention two or three plantations, and add a hint upon this fubject, which I flatter myfelf will deferve notice.

Mr. Marfham, of Stratton, ranks firl in priority, as he (like the late Lord Bathurft) has planted trees with his own hand, that he might fell for fix or feven pounds a piece, if he chofe to cut them down, and, among a great number of other remarkably fine trees, he has a Spanifh chefnut, which he planted a nut, with his own hand, and afterwards tranfplanted it into a poor fandy foil, which now runs, timber 58 feet, and fquares upwards of 22 inches at the butt, fo that it muft be, at lean, 80 cubical feet of timber; and I truft this truly refpectable country gentleman will live to fee his favourite tree increafe confiderably more, for he is a comfort to the neighbourhood he lives in, and has obliged the world with many ingenious obfervations upon nature, and has recently made 
fome laudable experiments for facilitating the growth of timber, by keeping the bark clean from mols, and opening the furface of the earth round the trees, to let moifture and air into the roots: and though this alfiflance cannot be given to trees upon a very large fcale, it may often be adopted in favourite fpots, and fmall plantations, to great advantage; and he has fo judicioufly fcattered a great number of trees on the fides of the road near his refidence, by planting them in the Flemifh ftile, without their heads, that they have flourifhed extremely, and changed the dreary profpect of a poor common to an agreeable fylvan fcene.

This practice of Mr. Martham's having been mifunderftood, from my former way of defcribing. it, it is incumbent on me to give it fome explanation.

In Flanders, where they plant trees eight or ten feet high, it is a very common thing to ftrike off part of the fpray, and fometimes the top itfelf, to prevent the wind from having too much power over it, till the roots have taken hold.

Mr. Marfham imitates this practice, and by fo doing, has raifed a great number of valuable trees upon a poor bleak heath, where he could not otherwife: have raifed them at all; for he did not like to deprive the poor of their herbage, by inclofing 
clofing a part of it for entire plantations, and if he had planted fmaller trees, the rabbits and hares would have barked and ruined them; or if he had planted larger trees, with their natural heads, they would not have grown at all in fuch an expofed fituation. And it muft be underftood, that thefe trees have not a ftiff formal appearance, like an old tree which is reduced to a pollard, but in the courle of ten or fifteen years, after they are planted, grow into a handfome fymmetrical form, for their heads are not entirely cut off, fo as to be left like a dead ftick, but only reduced in their heads and branches, and left fomewhat in the original thape they were inclined to take.

Mr. Berney, of Bracon, ranks next as a planter, in point of date, as he hąs paid great attention to it for upwards of fifty years. In the year 1757 , he obtained the honour of a filver medal for a large plantation of oaks.-His Spanifh chefnuts are very fine, many of them fourteen or fifteen inches girth, and his larch as much; and he has the merit of having done more to eftablifh the credit of the latter than any other perfon I know: he has put it to almolt all the purpofes of buildings, fuch as principals, fpars, lath, and boards; likewife to inany cabinet ufes, fuch as doors, tables, windowframes, book-cafes, chimney-pieces, and many beautiful fpecimens in carving. In frort, he entertaius the higbeft opinion of it; and, having made obfer- 
vations upon the proper feafon for felling it, as well as all other firs, he recommends it to be done in the months of July or Augult, as he has found, by experience, that the liquid which oozes out at that time of the year, almont immediately turns to a fort of rofin, which operates as a fiptic, fo that the wood is not fo much drained as at other feafons, but hardens and comes into ufe fooner, which is a hint worth notice $(a)$.

Among the modern planters, Mr. Coke unqueltionably ranks foremoft. He has planted, fince he has been in poffeffion of his eftate, four hundred and eighty acres of different kinds of plants, twothirds of which are meant to be thinned and cut down for underwood, fo as to leave oak, Spanifh chefnut, and beech, only as timber. His intention is to continue to plant fifty acres every year, till he has completely environed three thoufand acres of land, which is to compole his park and demefne farm. Thefe plantations already afford great cheerfulnefs; and, as the ground has more variety than many other parts of Norfolk, they will give a bold effect, and be truly correfpondent to the magnificent feat they are meant to adorn. I cannot quit Holkham, without taking notice of a very commendable part of Mr. Coke's practice in planting, which is, his allowing the neighbouring poor to plant potatoes $(\hat{b})$ among his young trecs, the frrlt two or three years, which is a great comfort to

them, 
them, keeps his land effectually clean, and faves, him a confiderable expence in hoeing (c).

Mr. Windham, of Felbrigg, is alfo a confiderable modern planter. His plantations are defigned to anfwer two purpofes, to ornament and belt round his park, and to extend his great woodland fcene nearer the fea, towards which, at two miles diftance, it forms a grand bulwark, and from which he looks down an eafy declivity, over a bold fhore, to an unlimited profpect on the German ocean. Moft of his plantations have been raifed from feed; and there is one that ftands unrivalled; it was fown with acorns, Spanifh chefnut, and beechmaft, feventcen years fince; has been already twice thinned for hurdle wood; the trees, moft of which are thirty feet high, being at the regular diftance of twelve feet, with a valuable underwood at four feet diftance. This plantation was taken out of the park, was well fallowed the preceding fummer to its being fown, and, during this ftate, there was a flock of theep in the park, which were continually laying on the fallows, to which, in a great meafure, I attribute its aftonifhing floridity, as it furpaffes every thing of the kind I ever faw, and therefore I mention this as a thing worth attending to.

There is another plantation which is highly deferving notice and imitation; it is a belt $f_{1} x t y-f_{1} x$ yards wide and nine miles round, inclofing the $\mathrm{M} 2$

eftate 
eftate of Mr. Galway, of Tofts, near Thetford. The merit of this plantation jufly belongs to $\mathrm{Mr}$. Griffin, of Mundford, who advifed Mr. Nelfon, whofe eftate it was formerly, to this undertaking. It was planted with a variety of trees, at fix feec apart, and coft ten pounds an acre. It was begun in 1770, and completed in 1778 . It has been thinned feveral times; and the trees, if fold at this time, would be worth fifty pounds per acre. But the advantage it is to the reft of the eftate, to fay nothing of its ornament, is not to be defcribed, as it affords fheiter and warmth to cattle, which next to food, contribute to their health and thrift; fo that the land is increafed in value confiderably. In Thort, if $\mathrm{Mr}$. Galway would now line his belt with deciduous trees, fuch as birch, beech, and chefnut, to repel the wind, which now begins to draw through the bottom of the plantation, as it confilts chiefly of firs, it would enhance the value of his eftate a full third.

There is great advantage in planting a large body of wood in a naked country, which is not at firft perceived. Where there is nothing to refift the cold winds, vegetation and cattle are cut to death, and nothing rich from the atmofphere can be retained. But plantations ftop the rapid current of the air, collect a denfity which helps to enrich the furface of the earth; and, moreover, by giving warmth and comfort to cattle, half the fodder 
der will fatisfy them; and by degrees, as the cattic couch under fhelter, the foil by degrees improves. This is clear to demonftration, by taking a view of Lord Petre's park, which, in the midn of a barren, dreary country, forms an agreeable thady retreat, covered with a pleafant verdure, and richly ornamented with foreft trees of large dimenfions. His Lordfhip is now confiderably extending his plantations, with great tafte and fuccefs, to the open parts which lie on the outfide of his eftate.

There are two other plantations of a recent date, which are highly deferving of notice. The firt is upon the eftate of Sir William Jerningham, at Coftefey, four miles from Norwich; the ground is beautifully varied, which is the more ftriking, as Norfolk is, in general, a remarkably flat country; and the river Wenfum, which bounds one fide of it, is another great natural addition to the place; but the plantations, which are large and flourifhing, have been made by the worthy owner with fo much judgment and true tafte, that they afford the beft leffon any modern improver or layer out of ground could advert to.

The other is upon the eftate of Mifs Norris, at Witton, quite in the face of the German ocean; which, by having been planted very thick, have, without any old trees to fhelter them, fo flourifhed, that, in the courfe of 22 years, it has, in one of the 
the moft cold and expofed fituations in the kingdom, changed a confiderable tract of naked land into an impervious woodland fcene. For this embellifhment, the eftate and neighbourhood are indebted to the taite and perfeverance of Mr. Ewen, who, though the plan was originally laid down by the late $\mathrm{Mr}$. Norris, has paid fuch attention to the execution of it, and improved upon it, befides, fo much, that I do not know of any eftate having received greater benefit, in a minority, than this has done.

I wifh to imprefs all men of fortune with the importance of extending their plantations to the dinant parts of their eftates, where foil and fituation are fuitable, and not merely content themfelves with the environs of their own demefne: and that they may be informed how valuable the Spanifh chefnut is above moft other trees, I take the liberty, on this occafion, to refer them to a letter of mine upon that fubject, publifhed in the Tranfactions of the Society of Arts, Manufactures, and Commerce, for the year $179^{2}(d)$.

It is, in fhort, the oak's ben fubfitute, and is a quick grower upon all loomy and clayey foils.Lord IValpole has this year cut down feveral trees of this fort, which were tranfplanted in the year 1724 , which meafured, upon an average, 44 cubical feet. They were taken out of a grove merely for 
the purpole of thinning it, fo that they were not the belt of the trees; his Lordfhip cut down one of the fame age which meafured 74 feet.

Before I quit this fubject, I will venture to recommend another tree to the attention of all planters upon poor light lands, which feems to exceed moft others in growth. It is the tall ftraight-growing pinafter, which is frequently planted with Scotch firs; and, when they grow up together, by many incurious people, is taken for a Scotch fir. But I have always remarked its fuperiority of fize when mixed with it, and of the fame age. In fhort, it frequently grows as faft as an alder, or an afh, and therefore, if it be planted merely with a view of being cut down for fuel, it will be found a very profitable tree in many parts of England: but as it will grow to a very large fize, it will, in my opinion, be found applicable to many ufeful purpofes, as it admits of being cut into very large fcantlings. As a decided proof of its advantage over the Scetch fir in growth, and confequently in value, I need only 1tate, that about forty years fince, his late Royal Highnefs IVilliam Duke of Cumberland made a plantation of nearly a hundred acres on a remarkably poor fandy land, adjoining to Bagthot Heath, in Surry, chicfly with Scotch firs, but with a finaller proportion of pinafters intermixed with them. The plantation is reckoned to have fucceeded extremcly well, and has been a great orna- 
ment to the country; but the Scotch firs do not average more than five cubical feet, whiln the pinafters are full forty; fome of them I have meafured, and found to be upwards of leventy feet.

When new plantations are made, it is always beft to make them in as large a body as the ground will admit of, and if there is time to clean the land well, I recommend fuch plantations to be made from feed in drills, rather than with feedlings, keeping the ground clean till the plants get high enough to protece themfelves: but it fometimes happens that fingle trees are planted with propriety in parks and lawns, upon frnall fwells and eminent fpots, where a large plantation would be too heavy. In fuch cales it is a good practice to open a very large hole, at leaft fix feet in diameter, and full eighteen inches deep, in the fpring, and the enfuing winter put three or four plants of different forts into each hole; guarding them with a triangle frame, which will be more durable than a fquare, and much cheaper than a circle; and, the ftuff being found, this may be erected five feet high, with pales fix inches apart, all workmanfhip and nails included, for 3 s. 6d. each. The reafon for putting four plants into a hole, is not only to have the greater chance of raifing one good tree, but it will fometimes happen, that two or three of them will unite and mix their branches together, and form a mont beautiful head of different tints, and by extending 
their principal roots different ways, draw fufficient nourifhment for a permanent fupport of their union.

I thall clofe my obfervations upon this interefting fubject, with a word of advice, by way of guarding againft a pernicious practice, which, though hitherto unknown in this county, has lately got fome footing in it-I mean the infamous cultom that prevails, in fome counties, of pruning up trees, by diventing them of their lower or lateral branches. When a plant is very young, it is fometimes allowable, to a certain difance, but fhould always be done with great caution; but when trees have begun to form themfelves, it is a fort of murder -it ftops the growth, and produces extreme deformity; for the fap, in the fpring of the year, being checked in its natural diffufion into the number of branches, into which it ufed to flow, bccomes diftorted

"As knots, by the conllux of meeting fap,

"Infeet the found pine, and divert his grain,

"Tortive and crrant, from his courfe of growth.

"SHAKESREARE." 


\section{$\mathbb{N} O \mathbb{T} \mathbb{E}$}

(a) Sir Thomas Beevor oblerves-" Where has it been "found that firs and pines are beft felled in the months of " July and Auguft? Since that practice is, here, too novel to "have had its truth confirmed by experience. Is not the " exudation of the fap of all trees, from its infpiffation in the "s winter, lefs abundant, and the turpentine retained in "thefe trees a prefervative to them? Some trees taken down " 7 or 8 years ago, at that feafon, by the writer of this note, "give him reafon to think the converfe of Mr. Berney's pro"polition to be true."

(b) Mr. Dan has the following remark:-" Notwithftand"6 ing I applaud the motive, I doubt the propriety of this "practice; conceiving that potatoes are injurious to young " trees, from the injury I have experienced, when they have "been planted amongft hops." I am, however, of a different opinion to Mr. Dan, and from confiderable experience, I have obferved, that potatoes keep the foil loofe, moift, and clean from weeds, and do trees great fervice in their early ftage.

(c) The following is Mr. James's remark, and breathes the true fpirit of philanthropy:- "Here is an example worthy " of general imitation.-Every man, in every fituation in life, " is placed within a certain fphere of action, and, whether it " is extenfive or confined, if he but does his duty, and em"braces every opportunity, which prefents itfelf, of doing " good, the path of life would be deprived of its ruggednefs; - 6 and if a cloud flould now and then intervene between us " and the fun-fhine of our happinefs, it would only ferve as 
"a very ufeful monitor, by inducing us to reflect, upon the " inftability of our prefent fituations. If we enjoy comforts, "in preference to others, it behoves us to be grateful; and "that lovely gratitude will be moft acceptable to the benefi" cent author of them, which prompts their diffuffion among?t si our fellow creatures. Riches never were the object of my "envy; but, in this point of view, they become fo in the "greateft degree."

(d) Mr. Strachey having intimated a defire to have this letter inferted here, I fhall publifh it in the Appendix.

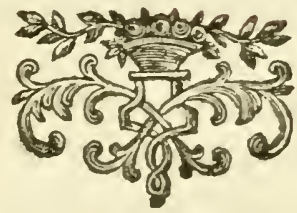




\section{Section XVII.}

\section{LIVE STOCK.}

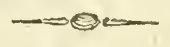

"HE horfes, as I have before obferved, are fhort, compact, active, and hardy; thofe of the original flanding, and thofe with the Suffolk crofs, in my opinion, may be confidered equally good; thofe which have the Lincolnthire crofs, as Mr. Marfhall very properly intimates, are not fo well adapted to the country.

The cows, which are natives, cannot be much admired; they are fmall, with turned-up horns, and generally of a red colour; but, of late years, the Suffolk polled cow, of the dun colour, is much introduced; it is not, indeed, quite fo hardy, but, where the pafture is tolerably good, is certainly more profitable.

The old fort fuit the cottager ben, as they have little more to give them, than the run of the common; but thole of the Suffolk kind are much the 
ieft for a farmer, not only as to produce, but as to the flock reared from them.

Oxen are very little uled in this county for labour; in no inflance, I believe, by farmers, and by very few gentlemen; but upon this fubject, I thall have more to obferve in another place.

The flock grazed or fatted, are about half Scotch, the one quarter Irifh, and the other quarter what are called home-bred.

The firft two forts are gencrally purchafed at St. Faith's, and other fairs, about Micliachuas; and, if they are in formard condition, one acre of turnips will put from five to fix pounds profit upon an ox by Lady-day or May-day following. Thofe which are not fo forward, are kept upon offal turnips in the winter, and fatted off in the marthes by harvef, when they fometimes double their price at market, within the year; but for a more particular account of the real profit of thefe cattlc, I muf refer my reader to a calculation unon them in the Appendix.

The home-breds were formerly not reckoned fo profitable as the Scotch and Irifh; but fince the introduction of the Suffolk cow, their credit is much increafed. - The average weight of a Scolch bullock, when fat, may be confidered at 50 flone, 
of $14 \mathrm{lb}$. to the flone. I remember one, a few years fince, of 80 ftone, which was reckoned very large. I apprehend, that the home-bieds may, in gencral, be made to average rather more, in weight, than the Scotch; and, to fhow what they may be brought to, I have authority to flate, that $\mathrm{Mr}$. Edward Betts, of Moulton, near Long Stratton, laft year fold a five-year old bullock, of his own breeding, for $£ 35$, the weight of which was 93 ftone, $61 \mathrm{~b}$. at $14 \mathrm{lb}$. to the ftone, befides 15 ftone, $8 \mathrm{lb}$. of fat.

The fheep come next under confideration; and here it is neceffary to premife, that great part of this county is known to have been, within the fpace of a century, a wild, bleak, unproductive country, comparatively with what it now is; full half of it was rabbit-warrens and fheep-walks; the fheep were as natural to the foil as the rabbits, being hardy in their nature, and of an agile conAnuction, fo as to move over a great deal of fpace with little labour. When great traes of this land were brought into a better ftate of cultivation, the Norfolk fheep gave great aid to the new improvement, as they fetched their fuftenance from a confiderable diftance, and anfwercd penning as well as any fheep whatever. Folding became in high cflimation, and, aided by marling, brought the improvement of the country rapidly forward. Soon after, the turnip fyfem followed, which enabled 
the farmer to improve his fock confiderably by better keeping; fo that, at this time, they are become refpectable and profitable in their return, and in as high eftimation, at Smithfield, as any theep whatever, for no better mutton can be put upon a table; and though they produce but little wool, it is of good quality. Notwithftanding this, there are fome gentlemen, and fome confiderable farmers too, who begin to dillike and defpife them, and prefer the Lincoln and Leicefter breed: but the Norfolk farmer will never be able to fublitute any other theep, that will anfwer penning fo well $(a)$ as the native fheep. The heavy Leicefterfhire theep has not activity enough to move over a lufficiency of ground to get his living, and therefore can never anfwer folding; and if the great farmer gives up folding, he lofes all his confequence, as he cannot keep his land fo well by any other means (b), and commits upon himfelf, a fort of felo de fe: therefore I would have him fully confider the value of this improvement, before he haltily adopts any other change of Rock, left, by fo doing, the value of the fold be loit.

Some little reverence is due to what his forefathers and ancient cuflom have fanctioned; therefore, even under this confideration, he may, perhaps, do wrong in parting with the fock that has long been naturalized to the foil, till he can firft 
fuily fatisfy himfelf, that the change will be permanently for his advantage.

Of late years, there has been a great rage for crolling the brecd of cattle; and though improvement may have been effected by it, in fome parts, it cannot be denied, but that it has done great injury in others. - in fhort, it fhould always be done with great caution, and, in general, it is beft to heep each fort of cattle as difinet as pofible in its kind, as every fort poffeffes fome particular advanlages: but when land becomes much improved, ftcck may be improved in proportion; and in fome inftances the breed may, undorbtedly, be croffed with propriety; but there ought always to be fome affinity or fimilitude between the cattle which are crofled. It is a manifent incongruity to match a horned bull with a Suffolk polled cow; or a Norfolk and a Leicefter fheep; or a Norfolk and a South Down; or any long wooled thecp with a Short wooled; but a Leicelterhire theep may be matched, with fome degiee of propriety, with a Cottfwold; and a south Down theep with a Berkfhire or a Herefordfhire Ryland.

I allow, that in Marfhland hundred, in gentlemen's parks, and in fmall tich inclofures, in the vicinity of towns, the Leicenterfhire theep, which has been lately introduced into fome parts of this county, will anfwer extremcly well; but, to fuppore 
pofe that the country would be benefited by their being introduced into all parts of it, to the entire exclufion of the native fheep, would be extremely abfurd; for it is a matter of great doubt, whether the country would not be nearly ruined by it. The went end of it would certainly be molt grieriouly injured; as a great number of what are now the finelt farms, would unquenionably revert back to fomething like their priftine ftate. Indeed, it feems to me very ftrange, that the Norfolk theep, which originally (before the introduction of turnips and artificial graffes) was the fole fupport of the Norfolk tillage, and has fince borne its full proportion in all the modern improvements, fhould, at this tine, fo far lofe its credit, as to admit of a doubt, with refpect to its fuitability to the foil, or its prolit to the breeder.

Thofe who keep ewe flocks, find them anfwer extremely well; for, befides the fleece and manure, the average price of the lambs is, at this time, twelve ihillings. Thofe who buy the wether lambs at that age, with a view of bringing them up for fatting ftock, after kecping them eighteen or nineteen months, generally fell them at an average of thirty fhillings, which may be confidered as a very handfoine profit, as they are only kept as ftore theep the firf twelve months, and when fatted, in general, an acre of turnips will do for eight; from which, 
which, however, a deduction muit be made of about ten theep, out of a hundred, for cafualty.

Mr. Purdy, of Egmere, a tenant of Thomas Wodehoule, Efq. whole flock is remarkably fine, fold a three-year old wether, of his own breeding, in Smithfield market, laft February, for fite guineas, which weighed $38 \mathrm{lb}$. a quarter, befides 30 lb. of loofe fat-a painting of which, may be feen in the office of Kent, Claridge, and Pcarce, in Craig's-court, London, and a print of the true Norfolk Ram, drawn from the breed of Mro Barber, of Dunton, is here introduced.

$\therefore$ The pigs are remarkably thin-haired and fuall, compared to the Hamplhire breed, but very prolific, and the pork excellent; but the inhabitants have no idea of making bacon, farther than as to hams and cheeks, which, however, they prepare extremely well. The number of fwine ufed to be very great, but is now fomewhat lefs, on account of the decline of the daries.

The poultry is fuperlatively good, efpecially the turkey, which has no equal, at leaft in flavour, which I attribute to the drynefs of the foil, and to the greater range which they have more than in other counties; and the confumption is very great, as well at home, as in what is fent to London, and other parts. 


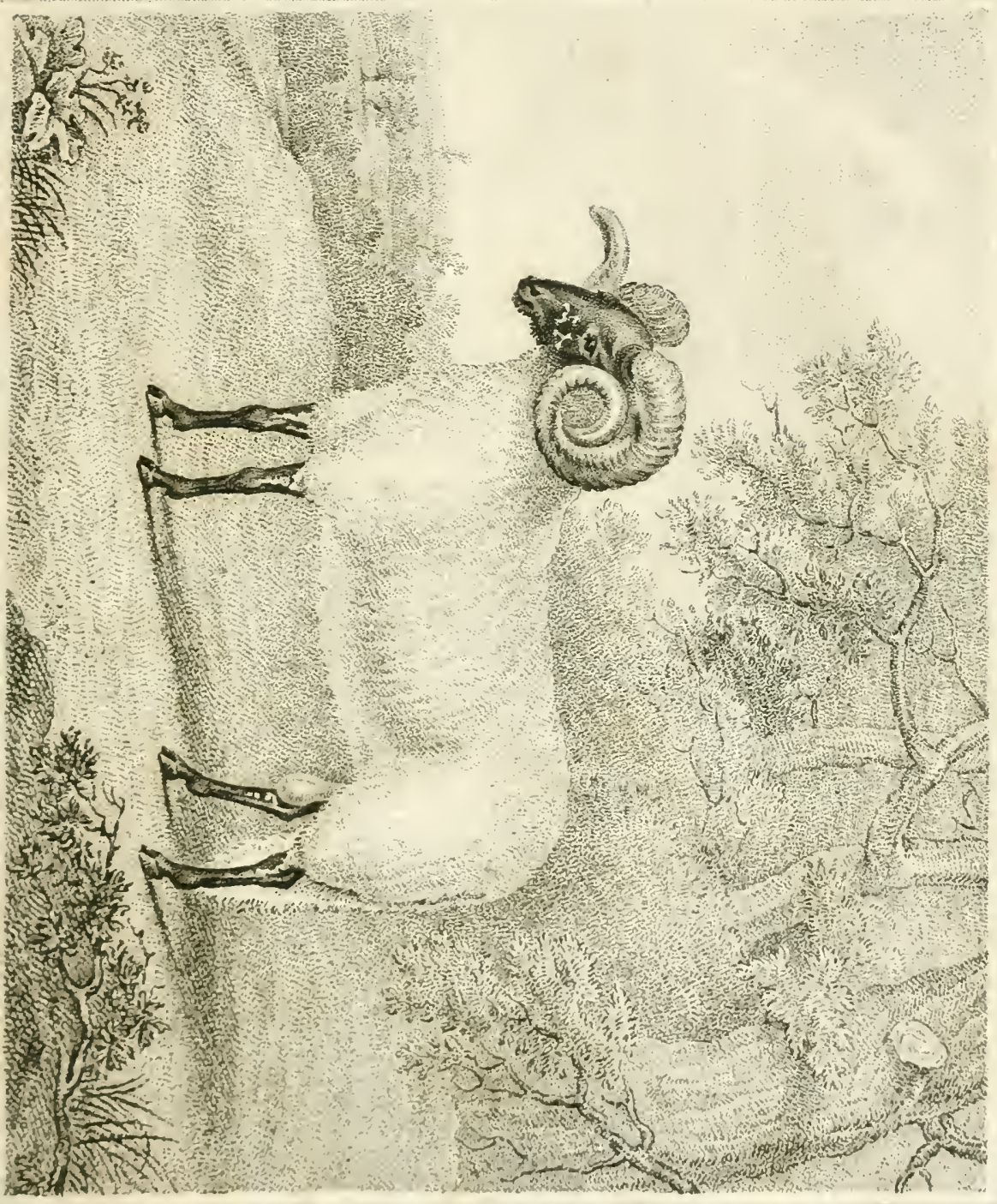



The pigeons are much fewer than formerly, as many of the pigeon-houfes have been dropt, on account of the injury which the pigeons do to thatched buildings.

The decoys are but few to what they were formerly; but, as there are fo many marhes, and feveral pieces of water called broads, it is prefumed, that many of them might be revived to advantage, as wild-fowl is become more valuable fince the communication to London is made eafier and quicker, by means of the turnpike roads.

Rabbits are very numerous, as the warrens are not only very confiderable, but many other parts are full of them, particularly near plantations, where they do great injury, and are very difficult to keep down.

The game is fill in great plenty, though not equal to what it was formerly. Many of the gentlemen are too tenacious of it, which makes the farmer, its natural guardian, lefs careful to preferve it; and it is too often a fource of difcord in the county $(c)$. 


\section{$\mathbb{N} O \mathbb{T} \mathbb{E}$}

(a) Mr. Baillie anks, "Is Mr. Kent quite certain, that "South Down, and fome other kinds of fhecp, will not fold "or pen as well as the Norfolk?" In the cold climate of Norfolk, I do not believe they will, at leaft, they have not yet been fairly tried; and why fhould a thing that has been long found to anfwer the purpole intended, to the full extent of all reafonable advantage that can be expected from it, give way to hafy innovation. Let the gentlemen firft try the experiment, and if, contrary to my opinion, it hould be found to be an improvement, then let the farmer follow them : but I am too much the farmer's friend to wifh to fee him try expenfive experiments, where the iffue is doubtful.

I with thofe gentlemen, who are fo fond of changing the native ftock, would acivert to what Mr. Marthall very fenfibly and juitly fays, upon this fubject, in his Rural CEconomy of this county, pages $3^{66}$ and $3^{67}$. He afferts, with equal confidence and truth, "that a valuable breed of ftock, adapted "f to a given foil and fituation, is an acquifition of ages. That " the Leicefterfhire theep (though he highly commends them " in their proper place) confidered as a breed at large, for " this county, are wholly unfit: they will not live, like the "Norfolk fheep, on the heaths and open ground-will not " ftand the fold fo well - will not travel fo well to the London " markets-or fell, when there, for fo much a pound as the "Norfolks," \&c.

Mr. Dann likewife doubts "whether I have tried the "South Downs." Certainly not-no one, as I have before obferved, has yet fairly tried them, though I will frankly allow, 
allow, that, next to the native theep, they would do better in Norfolk than any other; for they are a hardy, and a very good and profitable theep. All that I have contended for, is, that I do not fee the neceffity of a general change of the ftock.

(b) Mr. Baillie remarks farther-" How do farmers pay "their rents where no folding is practifed, and where the "land is as well cultivated, and the crops of turnips, \&c. " fuperior to Norfolk, and foil of no better quality? In an " inclofed country, folding is a barbarous practice, and the " time is not far diftant when it will be totally abolifhed." I wilh to know where this country is, that grows better turnips than in Norfolk, upon foil of equal quality? As to the latter part of this remark, I truft, I may venture to affert, that $\mathrm{Mr}$. Baillie will not, in this cafe, prove a true prophet.

(c) The following remark is made by Mr. James:-" I con"fefs myfelf averfe to any fyftem, which, like the game act, " is likely to become a fource of difcord and contention. I " don't know whether the intentional deftruction by the far" mer, owing to the reftraint he is under, is not more than "equal to what it might be, was this arbitrary act repealed." 


\section{Section XVIII.}

\section{BUILDINGS AND REPAIRS.}

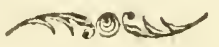

IT muft not be expected, that in a treatife of this fort, I flould enter into a defcription of the gentlemen's feats, which are in this county, though Holkham and Houghton are little fhort of palaces, and a valt many others are extremely fplendid and commodious. This would be foreign to the defign I have in view, which is merely to take into confideration, fuch buildings as are neceffarily coimected with agriculture.

This, however, is a confideration of the firft magnitude.

That a farmer thouid have reafonable accommo. dation, cannot admit of a doubt; but it is highly improper that he fhould be indulged in unreafonable or unfuitable buildings.

Farm-buildings in this county are upon a very refpectable footing, but, in my opinion, they are upon too large a fcale. 
Repairs are chiefly done at the expence of the landlord, and the charge of them is very confider. able, not lefs, as I have found by experience, than 10 per cent. including materials.

Farmers are very averfe to ftacking $(a)$, though wheat is preferved fivecter and better on ftaddles than in barns; they are always crying out for barn room; and they certainly are indulged in a greater proportion of it, than farmers in any other county. It is not uncommon to have barns, upon 100i. a year, which coft 300 . there are many fingle barns that have been lately erected, which have coit confiderably more than that fum; and fome ferr farm-houfes, upon farms of about 3001 . a year, have coft 1000 . This is certainly wrong, for fuch buildings make a great wafte of timber, and are unneceffary and, moreover, very bad examples, as one farmer will always covet a frmilar thing to what he fecs his equal in polfeffion of. I fhould much rather fee a difpofition in the country, to build a fufficient number of comfortable cotiages, for the induftrious labourers, than to run into an excefs of indulgence, where no good purpole can be anfwered by it (b).

Having fpoken of repairs in a general point of view, I will add a word or two refpecting the miterials. 
The old buildings were compofed chielly of clay, or laths and plaifter; but all modern build. ings are built with bricks, which are of a very good quality; but the lime is not fo good from chalk and marl, as it is in countries where it is made from the flone.

The covering is of three kinds, Dutch tile generally for the houfes, and the common pan-tiles for ftables and barns, or fea or marth reed, which is excellent in quality, and neatly put on. The general coft for reed and workmanthip, and every thing complete, is a guinea a fquare. No covering is fo good as this, as it will preferve a roof twice as long as tile.

Where ftraw is ufed for thatch, I earnefly recommend the excellent practice of the weft of England, where the fraw is combed quite clean of weeds, the ears of the corn cut off, and reed. (as it is there called) laid on in whole pipes, unbriifed by the flail. - The confequence is, that it is twice as durable, and, in its appearance, much neatcr.

Where new buildings are erected, it is effential to choofe the moft fheltered fpot which can be pitched upon, confiftent with the fituation of the land, becaule it is prudent to guard againt tempefts, 
pells, as much as poffible, and, becaufe young flock thrive much better in warm yards.

The following general rules, refpecting new erections, may be worth obferving.

Not to build any thing but what will be really ufeful. To build upon a fmall compact fcale; and, as much as poffible, upon fquares or parallelograms; not in angles, or notches. To build, at all times, fubftantially, and with good materials. Not to lay any timber into frefh mortar, becaufe the lime eats up and waftes the ends of it, long before the other parts decay; but to lay the ends into loam or clay. Not to put any windowframes or door-cales into new brick-work, at the time the walls are carried up; but to introduce a difcharging-piece, or lintel, over fuch door and window fpaces. The reafon of the laft caution is obvious; for as brick-work fettles, foon after it is up, the window-frames and door-cafes, on account of their ftrength, will not yield to it, but occafion cracks and flaws; but, when a lintel is made ufe of, the whole work fettles regularly together, and duor-cales and window-frames may be then introduced, with more propricty than before.

With refpect to the timber moft proper for building, I know of none that is to be preferreil to Spanifh chefinut, where it can be had, becaule 
it is very pleafant to work, and as durable as oak, though it feldom bears the price of it. (See a letter, on this fubject, in the Appendix.) In a maritime county, like this, where oak fells well, and deals may be had cheaper than in the inland parts, it is advifeable, in many inftances, to fell the one, and buy the other; as the one cuts to watte, and the other may be had in any fcantlings required.

In all paling, battoning, and other fences about the homeftall, nothing is more ufeful than pollards, and they fhould always be made ufe of on fuch occafions, becaufe they are, generally, the produce of the farm, of little value, and fave better timber. Sometimes they are ufeful in fheds, and fmall buildings for cattle.

All work, whether old or new, fhould be fet, as mucl as poffible, by the job, or great, for a fixed fum; always fubject, however, to infpection. and approbation when finithed.

In reparations, two points fhould be attended. to, in preference to every other confideration. The one is, to keep all the ground-cills or foundations conftantly tight, to prevent the wall or upper part of the building from warping, or setting out of its perpendicular; the other is, to keep the thatch or covering, at all times, whole; 
whole; to prevent wet from getting in to damage the timber.

When buildings are very old, and in bad condition, it is better to pull them quite down, than to be at much expence in patching them.

Tenants ought to find ftraw for thatching, becaufe it is the growth of the farm, and to carry all materials, for repairs, gratis; becaufe their teams and carriages are ready on the fpot, and they can often do it, at leifure intervals, without much inconvenience.

When farms are leafed, the landlord generally engages to put them in repair, and the tenant to keep and leave them fo. But eltates, under this regulation, are very often neglected, for when the landlord is not called upon, it is very natural for him to be carelefs, and, at the expiration of the demife, there is often a heavy unexpected charge brought on, for want of a little timely attention; and it feldom happens that a landlord can prevail on the departing tenant, to be at much expence in making good defects, and it is very unpleafing to be obliged to compel him to do a thing by force. Conftant attention not only reduces the expence of repairs, but brings them to a more regular and even charge. But, as no exertion or afliduity, whatever, in an owner or fteP 2 ward, 
ward, can be fufficient to attend to every acrident that happens, upon a large eftate, it feems effential!y necelfary, that the tenant ought, fome how, to be interefted in the prefervation of the build. ings, as well as the landlord, becaufe, as he is al ways on the fpot, he can remedy a breach at the expence of a fhiling, by taking it in time, which will con the landiord a guinea, by being neglected. He too, ty being on the fpor, can better attend to the workmen, to fee that they do not idle away their time, when tiey work by the day.

This obvious inconvenience I have, in a great meafure, remedied upon the eftates under my care, in this county, by obliging the tenants to be at one-half of all the expences of workmen's wages, not exceeding three per cent. however, to their fhare upon the rents; this, with three per cent. more from the landlord, and the allowance of the materials, befides, after buildings are once put into good repair, will, in general, be fufficient to keep them fo.

The advantage refulting from this, does not merely confin in the faving of the three per cent. but the tenant, by this means, becomes interefted in the prefervation of the buildings; and by that means the adage is verified, of A STITCH IN TIME, $\& c$. 


\section{NOTES.}

(a) Mr. Boys fays, "the expence of ftacking is great, and "s corn of lefs value out of ftacks, than out of barns." I ad. mit there is nore expence to the farmer, but it docs not ftrike me, as a reafonable thing, that merely to fave the tenant five per cent. the landlord thould be put to ten-As to corn being of lefs value out of ftacks than barns, I will not allow this to be a fact: corn, as I have before faid, is preferved fweeter in the former, than the latter, and better fecured from vermin.

(b) Mr. James obferves, that "this obfervation is admira"ble, and as the tenant expects from his landlord many in" dulgences, fo they ought, on their.part, to cultivate a dir"pofition of facrificing a few for the bencfit of their indur. "trious labourers. This example of moderation might fti"mulate his landlord to imitate him."

Mr. Strachcy having intimated a wint to have fome of the remarks in my Book of Ilints introduced into this Report, I have, accordingly, added fome of them to my former obfervations upon this fection. 


\section{Section XIX.}

\section{IMPLEMENTS OF HUSBANDRY.}

IHE plough deferves the firft notice, as it is compact and light in its conftruction, as will be hereafter fhewn, does its work remarkably clean, and is caflly managed with one handle $(a)$. The harrows are no ways remarkable.

'The waggon is remarkably heavy, which is the lefs neceffary, as none of the roads are rocky. It has, however, one acivantage in being made to lock fo far under the bed, that it will turn as fhort as a polt chaife $(b)$.

The cart is likewife heavier than is neceffary; and three-wheeled tumbrels are feldom uicd, though they would often fave thirty per cent. in the expence of marling.

There is one thing frequently practifed in hay and corn harvef, which is, the adding a couple of temporary fore-whcels, over the fhafts, and two oblique 


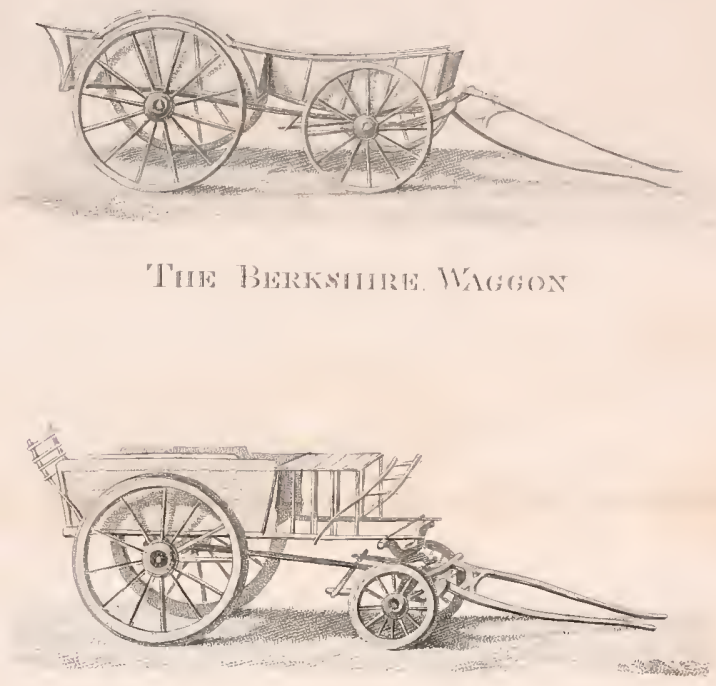

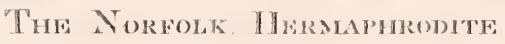


oblique ladders, a frame to the common carts, which anfwers the purpofe of a waggon (c), and in little farms it is a real object of frugality, and in larges ones a great help in a bufy feafon.-It is called an hermaphrodite, and I here fubjoin a iketch of it.

The Berkinire waggon, of which I alfo fubjoin a Iketch, is what I recommend, above all others, to the attention of the Norfolk farmer, being a horfe's draft lighter than his own, when loaded; being calculated to carry, larger loads; and being much lower, which is a very great convenience.

Drill-rollers have lately been introduced, containing rings round the roller, at about ten inches diftance from each other; thefe make drills in the land, and the middle part, between the drills, rifing into a ridge, the corn, by this means, falls chiefly into the drills, and is better depofited, and better covered, than it would if fown at random upon the furrows; and, confequently, fomewhat lefs feed does.

This is certainly a great improvement upon the broad-caft hufbandry, but, notwithntanding, it is, in my opinion, vafly inferior to dibbling.

Thefe rings were originally made with wood, and thod with iron; but they are now made very 
neat, and fold very cheap, in caft-iron, at the Norwich Foundery.

There is alfo another infrument, juft introduced into the Flegg liundreds, which is an iron bar faftened upon the piough-beam, and projecting out fo as to be dragged by the plough along the middle of the laft furrow, to that which is turning over; the end of the bar being cut into a fort of an edge, is loaded with weights to keep it down, and, by this means, makes a little dent which catches a great deal of corn, and what it does catch, is depofited (where land is only once ploughed) in the middle of the furrow, fo that the feed, when it ftrikes root, has the benefit of the beft part of the flag or inverted turf. This has not been much proved, but it promifes to be of fome benefit, and, I am inclined to think, it will be of molt ufe in barley fowing. 


\section{$\mathbb{N} \bigcirc \mathbb{T} \mathbb{E}$.}

(a) Mr. Baillie calls it "an awkward complex implement, " and what no perfon, that knows good ploughs, would re" commend or ufe on any account." This is a very harfh remark, and I truft he will here ftand alone in his opinion.

(b) Mr. Alderman Partridge "thinks, that if the Berk" Thire waggon can be recommended for durability, as well " as lightnefs, the Norfolk farmer cannot hefitate in adopt" ing this propofal." I can affure Mr. Partridge, that it is infinitely more durable, from obfervations and enquiries that I have made in both the counties. If a carriage is made of good materials, and put together with fymmetry, it is better, and will laft longer, than it will made too ftrong and clumfy. A heavy carriage, like a great horfe, is worn out by its own weight, more than by what it carries.

(c) Mr. Baillie further obferves, "that the fame number " of horfes, yoked in fingle carts, will carry more weight." Admitting this as a fact-a fingle cart will not admit of loading fo long a load of hay or corn, in the ftraw, which is what litated as the advantage of this carriage. 


\section{Section XX.}

THE ADVANTAGE OF LEASES。

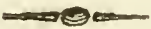

$\mathrm{T}$

$\mathrm{HE}$ ancient feudal tenures had undoubtedly a ftrong tendency to enflave mankind, by fubječting tenants to the controul and power of an arbitrary lord; but, like all other things, there were fome advantages to be found in the fyltem. Every man, who held land, had a certainty in it, as the tenant generally held his poffeffion for life. When thefe tenures were difcountenanced, by the liberal fpirit of modern law, fome new compact became neceffary, and terms of years were fubftituted in lieu of the former; for as land, properly managed, requires great expence, and feldom anfwers that expence in one year, it was but reafonable that the man, who applied his judgment, devoted his labour, and ventured his capital, fhould have fome reafonable time allowed him to reimburfe himfelf, and derive fome proportionate reward for what he had done. 
In the courfe of time, this term began to be reduced into a regular number of years. As moft of the land was formerly under the regulation of two crops and a fallow, the time allowed was from three to twenty-one years, and the latter, in the end, became the moft general limitation, and is the molt prevalent term for leafes at this time $(a)$.

That leafes are the firf, the greatent, and moft rational encouragement that can be given to agriculture, admits not of a doubt, in my opinion; but, of late years, there are very ftrong prejudices entertained againft them. In this county, it is rather the fafhion to grant leafes, which, in a great meafure, accounts for the improvements that have taken place in it; molt of the great eftates have been made from it: for, without leafes, no marling, to any extent, would have been undertaken, nor fo much ground brought into cultivation, by one-third, as there now is. The Holkham eftate, alone, frongly proves this affertion, as it has been increafed, in the memory of man, from five to upwards of twenty thoufand pounds a year, in this county only, and is ftill increafing like a fnow ball. Mr. Coke (b), the prefent owner of it, is a real friend to agriculture, and juftly confidered as one of the beft landlords in the county. From my particular knowledge of him, I can fay, that at leaft two years before his leafes expire, he puts the terant upon a footing of certainty, by nating

$$
Q_{2}
$$


to him, the terms he expects for a renewal of his leafe, that he may have time to look out for another farm, in cafe he does not like the conditions that are offered to him; but, though the advance of rent is often very great, I have never feen an inftance of any tenant leaving him, unlefs grown too far in years to be able to continue. The flipulations and refervations in his leafes are founded, too, upon principles of equity, and con. fift in no unneceffary repetition, or unreafonable exactions, being couched in plain terms, fuch as ought to compofe a liberal contract between a gentleman and an indufrious tenant; which may be worth imitation, in thofe who are fond of crowding their leafes with overbearing compulfatory claufes, tending more to create obedience and fervility in their tenants, than to promote good hufbandry $(c)$. There are fome few eltates, in this county, of a very confiderable fize, where leafes are entirely withheld; but it is evident, that thefe eftates are obliged to be let for, at leaft, 20 per cent. lefs than what they would be, if leafes were granted $(d)$. In many other counties the prejudice is fo frong, that an owner would almont as foon alienate the fee fimple of his eftate, as demife it for a term of years. I will not be fo harfh as to fay, that this diflike to leafes arifes from obfinacy or want of fenfe, but it is certain?y an unfortunate prejudice, which the proprietor takes up, and tends greatly to injure the public. One of the 
arguments made ufe of is, that it makes the tenant infulent and independent. There may be fome few inftances of this fort, but they ought not to be allowed to operate to the general injury of a country, howerer indifferent a gentleman may be to the advantage of his own purfe. A man of large landed property owes, in my opinion, fomething to fociety, and ought to get rid of his prejudices, where they affect the community $(c)$. Providence, who put him in poffefrion of his property, undoubtedly meant that he hou'd in fome fort act as a public feward, and it cannot be right that he thould wrap up the talent entrufted to his care in a napkin. It grieves me to go into a country, which I often do, and find it almolt in a ftate of nature, becaufe, the foil being wet and expenfive to cultivate, the tenant cannot afford to do it without encouragement, and the owner's infurmountable objection to leafes, keeps him from granting the fort of encouragement which is effentially neceffary. The yeomanry, in fuch parts, are upon a wretched miferable footing; the public fuftains a raft lofs; and the owner has, in lieu of the comfort he might beftow, and the good he might do, no other confolation than that he has the county more at command. But even this is a miltake; for I have, except in few inllances, always found a tenant as obliging and well behaved to his landlord, when he had a lealc as when lre had not. 
The arguments in favour of leafes feem to me fo powerful, that I could not, on this occafion, fupprefs giving my full fentiments relating to them; and it feems unreafonable, to the greateft degree, to expect a tenant to hazard all he is worth, and derote the beft part of his life, upon an eftate, which, upon the death, or perhaps the mere caprice, of his landlord, he is liable to be turned out of at fix months notice. I will not, however, deny, that there may be fome reafonable exceptions againt the practice I wilh to recommend, where lands lie near a gentleman's houfe, part of which it may be an object to take into hand; or, if a minor be very near of age, or if there be any immediate deifgn of felling an eftate, it is not prufent to grant leafes, becaufe, in the latter cafe, a purchafer may with to enter into inmediate poffeflion, and may have particular objects in view, which will induce him to give a higher price than he would, under the idea of purchafing merely to pay him a reafonable intereft. But, except in thefe infances, leafes, in my opinion, cannot be too firongly recommended; for I am certain, that where eflates are under an entail, or in a family that has no idea of parting with them, leafing is, unqueftionably, the molt effectual means of raifing their value, as the owner, by this means, has it in his power to ftipulate for improvements, in what manner and proportion he pleafes $(f)$, which he cannot do by any other means fo well. 


\section{$\mathbb{N} \mathbb{N} \mathbb{E}$.}

(c) Mr. James remarks, that "i leafes, moft affuredly, nay " be granted, for too long a period, as the contrary. That 6: juft equilibrium of interelt, which is fo effential between "the landlord and his tenant, would be in danger of being " deftroyed, by running into either extremes: if a leafe is " for a Short period, the latter is without any ftimulus to " employ his capital in improvements of any kind, and it " very frequently may prove a temptation to injure the farm, "by with-holding even thofe which are abfolutely neceffary; " on the other hand, if the leafe is for too long a term, the "tenant is likely to become too independent-twenty" one years I conccive to be the true medium. But that any "fhould be mad enough, and fo completely blinded to their "own intereft, and that of fociety, for a conncetion there "certainly is, as I have before obferved, not to grant any "leafes at all, is fcarcely to be believed.-Trace this to its "fource, and you will difcover it to proceed from prejudice, " the legitimate child of ignorance and pridc."

(b) Mr. Baillie very properly obferves here, "that Mr. " Coke is one of the beft friends to agriculture, in all its va"riations, that this inand affords, and is deferving of being. " hold out as a pattern."

(c) Mr. Strachey thinks, "f a full abitract or copy of one "s of thefe leafes in the Appendix will be ufeful." A fhort abftract thall accordingly be inferted.

(d) Mr. Wagtaff fays, "this doetrine of leafes, with the " fubfequent remarks on their expediency, is founded on 
" faits not, I believe, to be overthrown, as, indeed, the pofi" tions, educed from thefe facts, are warranted by reafon, and " are eftablifhed on the balis of the facts themfelves."

(e) Mr. Dan fays, "I am glad to find, that my obferva. " tions, ftated in other Reports, on this important queftion, " are fanctioned by this refpectable reporter."

( $f$ ) Mr. Baillie fays, " this is mot liberal and excellent " reafoning; it is only in very few parts of this ifland, where "we find good farming, except under long leafes."

Mr. Dan further obferves, that "thefe are fuch ftrik" ing inftances of the advantage to the landlord, by granting "leafes, that I hope they will have a proper effect on thofe " who are prejudiced againft the practice."

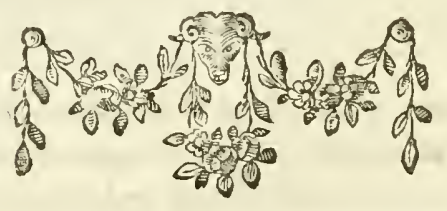




\section{Section XXI.}

\section{YHE SIZE OF FARMS CONSIDERED.}

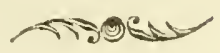

THE comparative produce of great and finall farms, is a queftion of the greatef importance, that . can come under the confideration of the Board of Agriculture, and is highly deferving of its moft ferious atiention. It is a fubject ou which no perfon can fand ncutral, but muft take a decided part one way or another. Much has been faid upon it, but very little proved-becaufe it is very difficult io form calculations, that would be conclufive, unlels real occupiers could be induced to lay open their profits and expenditure, which cannot be cxpccted; it is therefore from obfervation and conjecture, that arguments pro. and con. can be deduced. It thould, however, feem, even upon a flight confideration of the fubject, that agriculture, when it is thrown into a number of hands, becomes the life of induftry, the fource of plenty, and the fountain of riches to a country; and that monopolized and gralped into a few ha:ids, muft difhearten the bulk of mankind, who, 
by this means, are obliged to labour for others, inftead of themfelves, muft leflen the general produce, and greatly affeet the community at large.

The arguments generally made ufe of in favour of large farms, are, that a great expence is faved in repairs and labour, particularly in doing the culture with a lefs number of horfes; that a large capital in farming is as necellary, as in trade, for without a large capia!, no confiderable improvement can be undertaken or effected, nor a proper or fuitable flock kept upon land; and, that as to corn, heavier crops are grown, by means of the land being better worked and manured.

The arguments for fmall farms, are, that they reward merit, encourage induftry, fill the markets with plenty, increale population, and furnin the beft clafs of men in all fubordinate llations of life.

$\Lambda$ s to the firft, refpecting repairs, it muft ftand admitted; but, as an ample drawback from that advantage, tie land is, in general, let, at leaf, 20 per cent. cheaper in large, than it is in fmall farms. As to its being done with lefs expence, that is, with a lefs number of horfes, if that were a fact, it would certainly be a great advantage to the public, but, when the great farmer's riding horfes, and, fometimes, other horfes of pleafure and lux- 
ury, are added to thofe ufed upon the labour of a farm, no credit will be due to this affertion.

That a fuficient capital is as neceffary in farming, as in any branch of commerce, muft be allowed, but it does not hold good, that becaufe a man has but a finall capital, he ought not to be fuffered to make ufe of it at all; fuch doctrine would be abfurd, impolitic, and inhuman.

That a large capital is more equal to great improvements, than a fmall one, is felf evident; but, except in fome few inftances, I cannot fee why the latter fhould not keep pace, in a proportionate degree, at leaft, with the former. Refpecting flock, no one can prefume to fay, that a little farmer can fet a fold fo well as a great farmer, but he generally keeps more milch cows, in propertion, than the latter, which makes ample amends to the public.

As to corn, I am not inclined, even in this infance, to allow, that better crops are grown by the great, than the finall farmer, unlefs it be by means of the former having a theep-walk, or fome o:her fimilar advantage over the latter; upon this particular point, I thall refer to the comment of Mr. Cole, of Loddon (a).

So far, I have endeavoured to carry on a comparative ftatement between great and finall farms,

R 2 
as far as relates to a gencral anfwer to the conmon outlines of obfervation on them: but there are other remarks to be made, of great confiderationthe firt is, as to the effect they have upon fociety at large. Here, I believe, it will be pretty obvious, that if there were none but great farms, the common articles of confumption in every family would be fo diminifhed, that the middling race of mankind would not be able to fupply their tabies, and the common labourer would be abfolutely farred; for there would be no butter, cheefe, pork, eggs, or poultry, to be bought, as great farmers raife no more of thefe articles than they require for their own confumption. At this very time, chiefly, I believe, from the great farmers dropping their dairies, the markets of Yarmouth and Norwich are fo ill fupplied with butter, that it is become a matter of favour to be able to obtain enough for common confumption, notwithftanding the price, within a very few years, is increafed from $8 \mathrm{~d}$. to 16d. the pint, weighing $20 \mathrm{oz}$. And as to pigs, which diminifh of courfe with the daries, they are now become fo dear, that thofe farmers who want them in lean, to Thack their ftubble, cannot buy them under half-a-guinea a ftone $(b)$.

If great farms only are to be encouraged, which feem to be the aim of fome, hufbandmen of fmall capitals, let them be ever fo induftrious, will be effectuaily cut off from the common means of 
raifing themfelves in life, as there will be no channel for their introduction. Population will ikewife receive an irrecoverable blow from the fupprefion of thofe little hives of plenty (c). But mof great farmers, and, I am afraid, fome authors of cminence upon agriculture, and even upon population, tnay, perhaps, differ with me in opinion. I am not vain enough to fuppofe, that any thing I can fay will alter their opinion, but, for the fake of the community, and the particular comfort of the midding and lower claffes of fociety, I hope it may have fome weight with gentlemen of landed eftates, who are the natural guardians of the latter, and who would find their confequence much auymented, by a clofer attention to the inferior hufbandmen; and, I am greatly milaken, if their fortunes would not likewife be improved by it.

The inhabitants of this county are naturaliy induftrious, active, and perfevering, and have certainly the merit of having brought thoufands of acres into cultivation, which in any other part of England, except Suffolk, (where there is a congenial difpofrion) would have been defpifed, and fuffered to lic in an unproductive ftate, which is a fufficient confideration to induce gentlemen of landed property to encourage-as many hands as poffible in fuch ufeful cultivation.

The complaint againft great farms is not of any long ftanding-the evil (if I may be allowed to 
call it fo) feems to have encreafed in proportion to the decline of fairs and pitched markets. If it were the cuftom for the great farmer, as formerly, to bring his corn to the public market, as is fill the cafe at Uxbridge, Newbury, and fome other places, the home diftricis would never be fhort of corn; but while the great farmer and miller are allowed to fettle large bargains, over a bottle of wine, in a private room, from the exhibition of a mere pocket fample, a country may at any time be kept in the dark, as to the real quantity of corn in it, and little farmers, by this means, muft be quite ruined. I wifh, therefore, to fee fairs encouraged, and public markets revived: the laft of which are all reduced, in this county, (as far as relates to corn) to fale by fample only.

But, after all, it is the excefs of the grievance which I wifh to correct.-The evil is now fo great, that there are many farms of 1000 l. a year, in this county, and Mr. North's farm at Rougham, was lately ${ }^{17} 700$. but I have the fatisfaction to be able to fay, that he is now dividing it into four. The letting lands in fuch large farms, as this was, is evidently bad policy, if it were merely as to leffening the choice of tenants; for where they have one, in the prefent inftance, capable of carrying on fuch farms, they would have twenty in the other. 
I will, however, admit, though I ain an advocate for finall farms, that, as the country is now fituated, no farm thould be under 301 . or 401 . a year, and even thefe fhould be dairy farms, nor would I have any arable farm under 50 l. I will fill go farther, and fay, that the greateft number fhould be from $80 \mathrm{ol}$. a year to $15 \mathrm{Ol}$. none ought to exceed 200 . where the land is of a good quality; or 5001 . even upon the poorefl land, where great farms, on account of a large flock of theep, are inoft admiffible. The greater the difference in their fize, between the preceding extremes, perhaps, the better, as they will better play into each other's profits; fome will raife cattle to more ad. vantage than they can fat them, and others will fat them to more advantage than they can raife them.

I have made thefe remarks with freedom, but I truft, with temper and good manners to thofe of an oppofite opinion, and fhall be happy, if what I have advanced fhould have any effect upon thofe in whofe power it lies to correct the grievance complained of. 


\section{$\operatorname{IrOTES}$}

(a) Mr. Cole bcing afked his opinion upon this fubject, in a letter to his friend, Mr. Ewen, writes thus; - "I am of "opinion, that three farms, in this neighbourhood, of $50 l$. " rool. and 150l. per ann. produce a larger quantity of corn, " per acre, more cheefe, butter, live and dead ftock, for " market, than one farm of 300 l.

(b) In my former report, where I ftate the injury of great farms to fociety, Mr. Howlett has this remark:- "Notwith"itanding what is here intimated, the reafonings of $\mathrm{Mr}$. "Arthur Young, Lord Sheffield, and fome others, on the " oppofte fide, feem to me unanfivered." I thought it righ: not to fupprefs this remark, though it does not make for my argument, as I notice three cther commentators whofe obferratiuns cu make for it.

(c) Mr. James very jufly onferves, "that lately the en"largement of the farms, or the concentrating fmall farms " into one, is fo fevere a blow upon population, that I may "renture to hazard an opinion, that if this growing evil is " not very foon corrected, the nolt certain method of calcu"lating the population, will be by the poor's rates." And further obferves, in anfwer to the argument fet up in favou: of great furms, from land being poo:, "that he knows no " better mothod of amending fueh poor land, than by enich"ing it with induftrious inhabiturts." 
Mr. Wagftaff likewife, upon this important fubject, embraces the fame idea; he is pleafed to allow, that my remark is " incontrovertibly juft, and amounts to a proof, that fub" divided farms increafe the pcople, which acceffion of num"bers becomes national riches, where employ is at hand, and " it is capable of evidence, that fifty acres of land, under an "induftrious occupier, fupply more to the mafs of general "provifions, in proportion to his occupation, than the occu"pier of one thoufand acres:"-and, in another place, he thinks, that if the complaint was remedied, "it would be s: ultimately advantageous to the lord, his tenants, and their "common country."

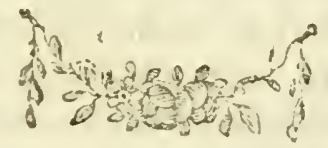




\title{
Section XXII.
}

\section{THE ADVANTAGE OF WORKING OXEN.}

\begin{abstract}
NEXT to the recommendation of the beft modes of culture, the cheapeft means of effecting it, deferve our attention, and, lafly, frugality in the confumption of the produce.
\end{abstract}

If it is a fact, which cannot be difproved, that oxen, in fome fort of work, are equal to horfes, in thefe cafes, they certainly ought to be preferred, becaufe they are kept at confiderably lefs expence, and lefs cafualty attends them. It would evidently be very much for the advantage of this country, if oxen were in higher eftimation than they are: upon every farm where three tearns are kept, one of them, at leaft, ought to be an ox team; for though oxen would not, perhaps, entirely anfwer the end, to the total cxclufion of horfes, there is, undoubtedly, a great deal of work that they would, as before obferved, do as well, particularly in carting and all heary work. In mol inflances, they 
are nearly equal to horfes, and, in their lupport, they are full thirty per cent. cheaper. At prefent no farmers ufe them in Norfolk; but Mr. Coke, Mr. Colhoun, and fome few other gentlemen, occafionally do, and I hope their example, ere long, will be followed by the farmers in general. It was with infinite fatisfaction, that I fome time fince learnt, that Lord Hawke, whofe experiments in hufbandry are very extenfive in Yorkfhire, has there fet an example of ploughing with two oxen to a plough only, which is attended with complete fuccefs, as they plough nearly as much as an equal number of horfes, and if the cheapnefs of their keep, and other circumftances in their favour, are confidered, they are certainly preferable to horfes. There is, in this country, a ftrong prejudice again $\mathrm{t}$ this generous animal, which is the firft thing to get over-when that can be removed, the credit of the ox will foon follow.

The principal advantage which the farmer would derive from oxen, is in the moderate expence of their keep, and in their being attended, as I have before obferved, with lefs rilk.

The beft way is, however, not to over-work them, for in that cale, they will require rather more hay than a horfe, and half as much corn, and if they are fuffered to fall into low condition, it will require confiderable expence and time to get them up again. 
The plan that I have found to anfwer bef, is this, fuppofe four were called a team, which, in this county, would be enough, and that one man was appointed to attend them; I would advife fix, inftead of four, to be the team, as one man might attend them at the fame expence as four, but I would only work four of them at a time, and let two of them reft two days out of the fix, by which means, they would, in fact, work only four days out of the feven. In the fummer months they fhould have a leafow or pafture to run in, where there is plenty of water and an open fhed, where they thould have a bait, the day they were worked, of green vetches, cut grafs, or any thing the farm might furnifh. In the winter, they fhould be kept in a yard, with the fame fort of thed for them to run into at pleafure, and here they fhould have plenty of barley or oat ftraw, and offal turnips, and in the days of working, cut hay and ftraw, mixed in equal proportions, inflead of $n$ raw, and turnips befides. In this manner, they will, in general, do extremely well, and will, at all events, carn as much as the value of their keep, fo that their work will be had for nothing. Another great advantage is, that in cafe of falling lame, there is no diminution, by that means, in their value, for if their fhoulders do not return a profit, their ribs will; but if a horle falls lame, at leaft, half his value is loft. So far I have defcribed the advantage of the ox to his employer- 
but to the public, the advantage is fuperlatively Ariking.-The ox, when labouring, does not confume fo much corn as the horfe, for, according to my plan, he would not confume any; and when his labour is done, his body goes to the nourithment of men-but the body of the other is good for nothing but to feed dogs.

The more the number of horfes can be leffened, the better for all ranks of people. The confumption by horfes, efpecially horfes of pleafure, and luxury, is aftonithing; for though a horfe in agriculture, does not confume above three acres of the fruits of the earth in a year, a horfe kept upon the road, eats yearly, in hay and oats, the full produce of five acres of land. A man, allowing him a pound of bread, and a pound of meat a day, or in that proportion, not quite an acre and a quarter; and as the poor cat but very little meat, it cannot be put at more than an acre to them: fo that one of thofe horfes eats nearly as much as five men. The more, therefore, we reduce our number of horfes, the more plentiful will be the fruits of the earth for man. Under this idea, perhaps, the tax upon horfes of pleafure and luxury may be a real advantage to the community. I.et any perfon but confider how thefe horfes fweep off the produce of the carth: I am told, and I believe, from good anthority, that in the city of Norwich, not quite fifty years fiuce, there were only twelve car- 
riages of pleafure and luxury, and that there are now feventy-two, including poft-chaifes, and thirteen hackney coaches befides; and if we allow three horfes to each carriage, upon an average, allowing for change, this will make a difference of 219 horfes in the city of Norwich only. At that time, there was only one coach to London; now there are two mail coaches, and two heavy coaches; and, as there cannot be allowed lefs than fixty horfes to each mail coach, and fifty to each of the others, this makes an increafe of 170 horfes more.-There is alfo a coach to Lynn, and another to Yarmouth, which cannot take lefs than twenty horfes more-here then is a difference, upon a round calculation, of 409 additional horfes, in what affects Norwich only; which, at five acres to a horfe, confume the additional produce of 2045 acres. If this mode of calculation be extended to other towns in the county, it will amount to a very great number of acres, in the aggrcgate, and multiplied by a fimilar increafe in all other parts of England, will fhew, that one grcat caufe of the dearnefs of provifions, is owing to the number of horfes which are kept more than formerly. 


\section{Dection XXII.}

\section{COMMERCE; OR A STATEMENT OF EXPORTS.}

\section{HE credit of a country is ufually confidered in} proportion to its general produce. If its agriculture does not produce more, in the whole, thar what is fufficient to fupport itfelf, and its own rural trades, it mult evidently be minus in the common fcale of production; becaufe erery country muft at leait look for affitance from fome clothing manufactory, though foreign luxuries were totally out of the queltion. lisut if the hulbandry of any particular difrict can fupport itfelf and its local trades, and furnifh half as much as it confumes. either to encourage manufactures at home, or to fupply foreign maikets, it may fairly be denominated a good country.

That Norfolk will ftand eminently high in reputation, when viewed in this light, will not admit of a doubt from any perfon who is futficicntly acquainted 
acquainted with its powers. But as fpeculations of this fort may be new to many perfons who may perufe thefe remarks, I thall endeavour to explain through what channels this great abundance fwclls to fuch a head, that imitation may fecure the fame adrantages, where congeniality of circumfances will admit of it.

In a good corn year, when there is a free exportation, it has been faid, that the four Norfolk ports cxport as much corn as all the reft of England; which I believe to be true, for it is feldom lefs than a million fterling in value, and often more; and though fome of the com comes down the Waveney out of Suffolk, and fome down the Ouze from two or three of the midland counties, this addition feldon bears the proportion of more than an eightl part of the Yarmouth export, and a third of the Lyun, which is not more than a tenth upon the whole.

The following is the neareft calculation I can make of the ufual excels of corn, and other articles of provifion, fent yearly out of the county, after referving not only a fufficiency for its people cmployed in agriculture, but for fifty thoufand home manufacturers, and fix thoufand feamen. 
The corn I am able to flate with accuracy, as I have obtained it from the Cuftum-houfe books, where the quantity exported is regiftered $(a)$. The cattle I cannot be fo confident of; but I have taken all the pains in my power to glean up the bef information that could be obtained; and where I have deduced any thing from compariton, I have taken care to be within the limits of juftification. The bridges of St. Germain and Magdalen, afcertain, in fome degree, the number of Scotch and Irifh cattle brought into the county; and the turnpikes leading out of the county, together with the affiftance which I have had from $\mathrm{Mr}$. Archer, and other intelligent falefmen at Smithfield and St. Ires, cnable me to come pretty near to what I conceive to be the truth.

Laft year there were actually 20,594 fat bullocks, brought from Norfolk to Smithfield and Iflington, and about 3 coo to St. Ives and other places; but, cither from the war or fome other caufe, this is confidered rather as a larger fupply than ufual; but they may be fafely taken at 20,000 as a yearly average, about one-quarter of which are lome-bred beafts, and the remainder Scotch and Irifh. The fheep are fuppoled to be upwards of 30,000 ; at lean they may be lifely tiken at that number. Objects, fuch as bine, butter, rabbits, poultry, Sre are not of iu much confequence, but fulfice it, thit they mail all be moderately ellimaled. 
The return from the Norwich manufactory, I fhall not include in my aggregate, as there is a great importation of coarfe wool, to fupport it, from Lincolnthire and other parts : nor thail I fet any value upon the whale or mackerel fifheries, as they are very precarious; but as the herring fithery is a permanent, though alfo a variable branch of provincial profit, and is wholly fed and fupported by the county, I think it fair to include it.

In thort, manufactures are to be confidercd as an object deferving a feparate inveftigation. But they are, undoubtedly, more deferving of encouragement in a productive, than a fterile country; efpecially where the induftry of the inhabitants is fingularly meritcrious, as is the cafe at Norwich, where new objects of manufacture have recently been introduced, fince the woollen has declined; but flill it would be better if the manufactory, which has been fo long familiar to the city, could be encouraged, fo as to regain its former fplendour and extent, which, it is fuppofed, might be the cafe, if, through the affiftance of Government, a free communication could be opened with China, where, if I am rightly informed, the Norwich goods are in a confiderable degree of credit (b).

I Thall begin my recapitulation with the corn, which is to be confrdered as the yearly average 
which has been exported to forcign parts and coaftways, for the laft three years, which were far from being prime ones.

The excels of each fpecies of grain, after deducting an equal quantity to balance what is occafionally imported, and alfo an eighth past from the port of Yarmouth, upon all grain for tle fuppoled proportion furnifhed by Suffolk, and a third from Lynn, (upon all, except barley) fuppoled to come down the Cuze out of the midland counties. But, it is conjectured, as much barley goes up the Ouze as comes down it. Premifing this, the account will ftand thus:

\section{FROM TARMOUIH.}

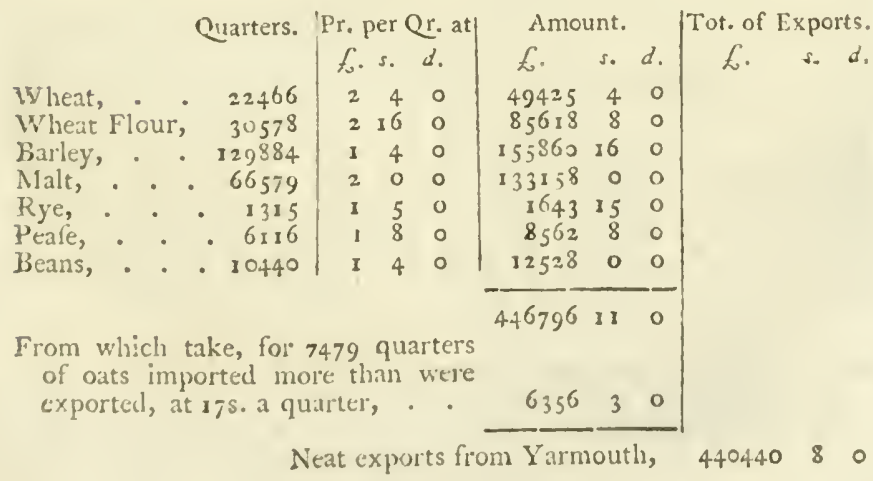




\section{FTEOI LINS.}

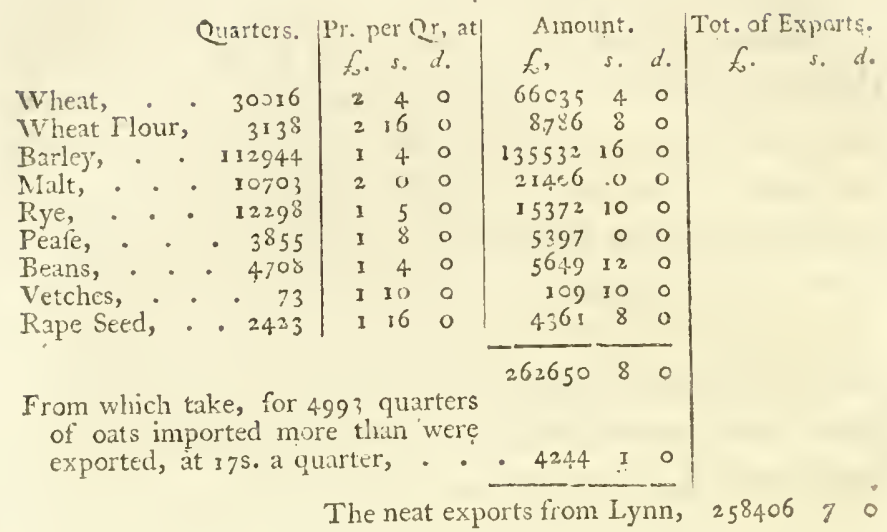

N. B. The excefs of linfeed imported, is about equal to the muftard feed exported.

\section{FROMIIELIS.}

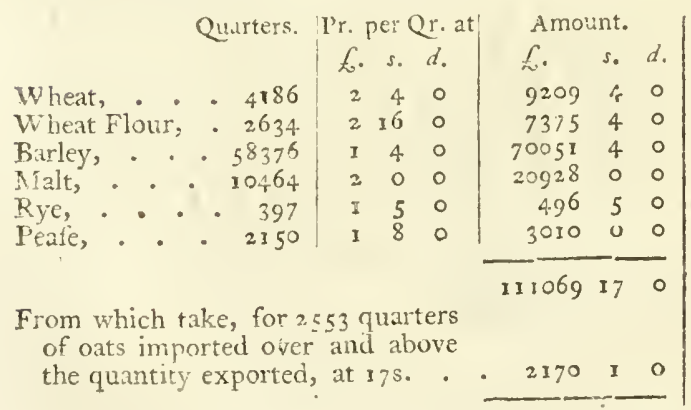

Neat exports from Wells, 108899160 


\section{FROM BIACEENEY ANDD CLAT.}

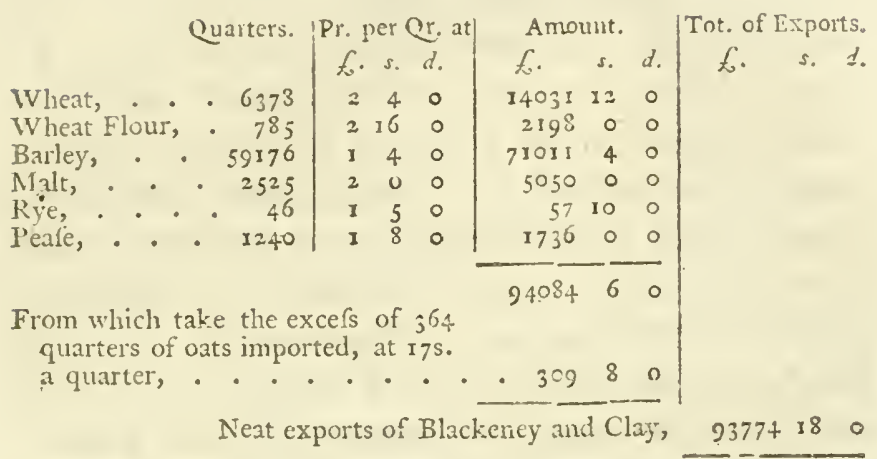

Tptal amount of the whole county, after diclucting

for the Suffolk and midland proportion . . 901521 90

\section{$\mathbb{C} A T T L \mathbb{E}$.}

fo. s. d. f. s. s. d.

5000 home-bred bullocks, at $\mathrm{xcl}$. $\quad 50000 \quad 0$ 15,000 Scotch and Irith, the fatting pro-

fit which may be fer at 5l. each, . 75000 0 30,002 theep, at 1 l. 10s. . . 4500000 Swine, not lefs than . • • . 10000 00 Rabbits, at leaft . . . . 1000000 Dairy articles, ahout . . . . 80000 o 0 Poultiy and game, . . . . 300000 ivool, conjectured to be about . . $=0000 \quad 00$ The herrings exported, . . . 5000000 50,000 lambs, at $12 \mathrm{~s}$. . . . 3000000

37300000 Add, for corn, grain, flour, \&c. as before ftated, . 901521 90 Total yearly produce fent out of the county, . 127452190 
I have purpofely brought the whole into money, with a view of thewing with the greater eafe, what number of perfons this extra, or fuperabundant produce is equal to the fupport of. And if wc apportion ten pounds for the fuftenance of a human being, one with another, which muft be acknowledged to be a liberal allowance, where Inxuries are excluded, it will appear, that this county fends out a foreign fupply for upwards of 127000 perfons. And if we take the 56,000 employed in the home manufactures and navigation, from the whole population of the county, it will thew, that the county furnifhes more than a fufficiency for double the number of perfons employed in agriculture and its appendant trades.

Every impartial inan, who confiders this vaft produce, muft be fiuck with aftonihment; and as Norfolk is far from being naturally a good country, it mun, undoubtedly, be to art and induftry, that this great fource of erealure is to be afcribed. It is evident? $y$ fo great, that no part of England, not even the famous vales of Taunton, White Horfe, or Evefham, are fuppofed to exceed it in proportion of corn.

Government muft certainly draw from this county a much greater portion of revenue, than from any otler; for as nearly one-third part of all the arable land is fown with barley every year, 
and as the barley crop is generally very good, (half of it being fown upon clean land after turnips) the return which it muft make, when traced through the malt-houfe, brew-houfe, and diftillery, will be found to amount to a fum almolt incredible.

I do not exhibit this fatement as a panegyric on the county; but to point out to the Board of Agriculture, how beneñcial this kind of hufbandry is above all others; not only to the individual, but to the public revenue: a moft powerful argument this, for Government to give all polfible encouragement to inclolures in general; and a grand inducement for other countries to follow the like courfe of hutbandry, wherever the foil will admit of it. 


\section{$\mathbb{N O} \mathbb{T} \mathbb{S}$.}

(a) Lord Rofeberry has the following remark :- "Wherc "dutics are not to be paid, the Cufom-houfe books are not a " rule to judge by, as every exporter enters, at random, any " quantity he pleafes, and always more than he is likely to " export, to prevent the trouble and expence of a fecond cn"try, there being no neceffity or obligation for entering the " exact quantity they are to export. The debentures beirg "given on corn afterwards, on the real quantity fhipped; " and it is from the regifter of the entries only, however, " that this caiculation is made, or even the reports to parlia" ment, which make them very fallacious, and this members "s of parliament thould advert to." How far this may affect my calculation, I cannot prefume to fay : I have given my fatement, on the bef information I could obtain, and flatter myfelf, at leaf, that it is not far from the truth.

(b) Mr. Alderman Partridge, in remarking, in an other place, upon the trade of Norwich, " hopes the decline of the "trade of Norwich is but temporary." I truft fo too, and that it will revive and become profperous again. 


\section{OF NORFOLK. \\ Secton XXIV. \\ GENERAL OUTGOINGS。}

153

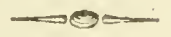

'UNo

NDER this head, I fhall not take notice of the common expences of cultivation by cattle, or labour by man, as thefe are charges which every fituation is alike fubject to, fave as to the difference in foil, and diftance from markets, \&c. but thall confine myfelf to the two great objects which affect landed eftates in general, namely, tythes and poor-rates.

As to tythes, the fubject is fo delicate, that great caution ought to be obferved in treating of it. In the firft place, the permanency of the title refts upon the fame bafis as all other eftates in the kingdom; therefore, nothing can be fo idle as half the fchemes which are talked of for frefh regulations of it. Whatever is done, mult be brought about by general concurrence and amicable agreement. 
The clergy, it is well known, are not poffeffed of all the tythes in England, perhaps, one-fourth of the corn tythes are in the hands of lay-impropriators, and, to confefs the truth, I have never found the former more exacting than the latter: therefore it is wrong to imprefs farmers with an idea, that if they could get rid of tythes, they would have their land the cheaper; on the contrary, every farmer, before he takes a farm, ought to confider, that the land he treats for is liable to fuch an outgoing, and fhould make a referve in his eftimate accordingly, which he does not always do, and by that means farmers fometimes deceive themfelves, and when a new clergyman comes and propoles an alteration, whether it is reafonable or not, they fet their faces againft complying with it, and difcord takes place in the parifh.

As to the general fcale upon which tythes are let in this country, I do not think it can be faid, that they are exorbitantly high; I believe the higheft price, for all tythes, is five thillings an acre, upon the very bef arable land, and two thillings upon the beft meadows and palure, at leaft it is fo, with very few exceptions. The more general compofition is three fhillings and fixpence an acre, for the arable, and one hilling and fixpence for the grafs. - In the very light parts of the county, it is two millings an acre, for the for mer, and ninepence for the latter; and there is hardly 
hardly an inftance, in fifty parifhes, of tythes being fet out, or taken up in kind.

Yet, after all, it is a moft unpopular eftate, and highly difcouraging to all new improvements in particular, becaufe, in this inftance, thefe undertakings cannot be effected without a very confiderable expence, and a certain thare of rifk, which the adventurer muft be fubject to, before he can derive any kind of benefit from his undertaking; but the tythe owner, in this cafe, comes into his eftate without any of this charge or inconvenience.-It is in this light, that tythes are grievous, and want better regulation; and, therefore, if a general cultivation thould take place, of the commons and walte lands, it is to be hoped the wifdom of the legiflature will be able to adopt fome regulations, even with the concurrence of the clergy, which may afford greater encouragement than is now the cafe. The exemption of three years, after wafte land is firft broken up, is evidently too fhort, and fhould, at leaft, be extended to feven. As to the total extinction of tythes, though, perhaps, it might, and, I dare fay, would be a great comfort to the clergy, and of great fervice to religion, yet, I doubt, it would be extremely difficult to fettle fuch a proper cquivalent as thould keep pace with the times. It could not be, I prefume, done in any other way, than by referving a corn $\mathrm{U}_{2}$

rent 
rent, or a certain fum of money, to fluctuate in proportion to the general fcale of provifions.

Poor-rates, which no longer back than twenty years, were fo light, that a farmer, when he went to take a farm, hardly thought it worth while to enquire the amount of it; but now it is become the firft queltion he muft afk.

The caufes of the aftonifhing increafe of thefe rates, it is prefumed, will chiefly be found in the rife of provifions, beyond the proportional rife in the price of labour. There may be fome other caufes, but this is the chief.

When this great alteration firt began to be felt, the Houfes of Indultry, of which there are feveral in this county, took their rife, and, for a time, there was great expectation of advantage from them, but I am informed, that fome of them, at leaf, have been for fome time upon the decline, and this laft year of fcarcity, they are minus in their accounts, fo that, it is to be feared, they.will not anfwer the end that was expected from them. The grierance, therefore, in and out of the houles, is become of a mon ferious nature; there are few parifhes now, that pay lefs than five or fix fhillings in the pound, upon the rack-rents. In the parith of Hevingham, where I refide, they are nine fhillings in the pound; in the parifh of Bux- 
ton, on one frde of me, they are ten; and in the parifh of Marfham, on the other fide, they are fixteen; fo that, in the latter place, more is paid to fupport the poor, than the landlords put in their pockets: for, after they have paid land-tax, and kept their buildings in repair, they do not get above fifteen thillings. The obrious conlequence of this is, that where an acre of land would be worth twenty fhillings, if there were no poor rates, it can only be worth ten flillings fubject to them.

There is one material reafon, however, to be affigned why the poor rates are to very high in the parilh of Marfuam, and many other parifhes, not far diftant from Norwich. In the year $17: 2$, an act of parliament parfed, for regulating the workhoufes in that city, in which act, there is a claufe which prevents any apprentice, taken from any country village, from gaining any fettlement in Norwich.- This was eridently done to encourage the manufactory, when it was upon a profperous and flomilhing footing-but it has had a cruel effect upon the parifhes, which, originally, furnifhed the city with thefe apprentices; many of them married in Norwich and elfewhere, and, upon the decline of the trade, the city preferring its own poor, thefe frangers, for want of work, were obliged to return to thrir original place of refidence, and many of them bronglic 
brought with them large families. This feems to prove the neceffity and propriety of taxing trade, when it is flourifhing, to provide a fund for its poor, when it declines.

There is another obfervation which I have made, which is, that the larger the common, the greater number, and the more miferable are the poor.

In the parifhes of Horsford, Hevingham, and Marhham, which link into each other, from four to nine miles from Norwich, there are not lefs than 3000 acres of wafte land, and yet the average of the rates are, at leaft, ten fhillings in the pound. - This thews the abfolute neceffity of doing fomething with thefe lands, or thefe, uncultivated, will utterly ruin the cultivated parts; for thefe miftaken people place a fallacious dependence upon thefe precarious commons, and do not truft to the returns of regular labour, which would be, by far, a better fupport to them. 


\section{Section XXV.}

\section{RURAL EEONOMY.}

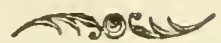

II Thall chiefly confine what I have to offer under this head, to the price of agricultural labour.

Some little difference is found in different parts of the county, but the following is the neareft general average that can be offered:

\section{pearly Taages.}

A head carter-nine to ten guineas. An under carter, or lad-five to feven guineas. A Thepherd-about ten pounds.

A yard man-about eight pounds. A dairy or houfe maid-four guineas.

\section{Daily שatages}

Of a labourer, till within a few years, was $14 \mathrm{~d}$. in fummer, and $1 \mathrm{~s}$. in winter, but they are now incrcaled, 
creafed, in molt parts of the county, to $18 \mathrm{~d}$. in fummer, and $14 \mathrm{~d}$. in winter.-Carpenters, thatchers, and bricklayers-2od. a daý.

\section{Secoing.}

DibBL1NG.- Theat, 1os. and peafe, 8s. per acre.

Setting.-Beans, 4s. $6 \mathrm{~d}$. and potatoes, $8 \mathrm{~s}$. per acre, including cutting of them.

\section{Dapnataing.}

Mowing.-One fhilling to 1s. 6d. per acre, according to the crop.

MAKING HAY by men, Is. 6d. a day; women, girls, and lads, $6 \mathrm{~d}$. and three pints of beer.

\section{CUming.}

Hozing.-Six fhillings, per acre, for hoeing twice in a mafterly manner.

\section{Đatoefing.}

REAPING and binding wheat, 5s. to $7 \mathrm{~s}$. pero acre.

Mowing barley or oats, 2s. to 2s. $6 \mathrm{~d}$. per acre. 
GATHERING in heaps, with thack-forks, 6d, an acre-with hand-rakes, 8d.

DRAG-RAKING. Two-pence an acre.

StACKING PEASE.-Four thillings an acre.

HARVEST WAGES.-For a man, the whole feafon, being well fed and allowed fix pints of beer a day, 2l. 2s. to 21.10 s.

\section{Than=cutting.}

Three farthings the heaped bufhel.

\section{Tyrelfing.}

WheAT. - Two fhillings a quarter( $(a)$, and two pints of beer per day.

Barley, oats, and BUCK. - One fhilling a quarter, and the fame allowance of beer.

PEASE.-Sixteen pence a quarter, and beer, as before.

Clover SEed, - Five fhillings a buthel, and beer, as before.

\section{sganuring,}

MARL.DDigging rather uncertain, on account of depth, but, in general, from 6d. to 2s. 6d. a cart load, of fix heaps to a load.

Filling and fpreading, $1 \frac{\mathrm{T}}{2} \mathrm{~d}$. for the firft, and $1 \mathrm{~d}$. for the latl, per load.

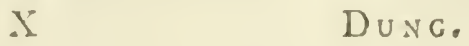


Dunc.-Filling and fpreading, at the fame prices as the marl-but here, 8 heaps go to the load.

\section{Jiencing.}

NEW BANK and DITCH.-One fhilling to 15 $6 \mathrm{~d}$. per rod, of feventy yards, according to the foil. The ditch, four feet wide on top, and three feet deep, properly floped, with a bank feven feet high, from the bottom of the ditch, inciuding the fetting of the quick-fets, and making a dwarf hedge of thorns on top of the bank and backing up the fame.

OLD BANRS REPAIRED.-Cutting off the thorns, cleaning the ditch, and effectually repairing the bank, the fame price as for the new work.

LOPPING and FAGGOTING.- Heading pollards, and converting the wood into faggots and round wood, 3 s. for 120 faggots, and 1s. for a waggon load of round wood.

Converting thorns inte faggots, 3 s. for 120.

\section{Draining.}

Making open drains, of two feet wide and two feet deep, 3 d. a rod, of feven yards.

Larger drains, ferving as fences, nine fcet wide and fix feet deep, 2 s. 6 d. a rod.

HOLLOW DRAININC, 4 d. a rod. 


\section{Thatching}

With fea or marth reed, all materials being found, 4s. 2d. a fquare.

Buildings with fraw, all materials being found, the lame as before.

Corn and hay ftacks, at 5 d. a yard, in length, taking in both fides.

\section{Shecp}

Wafhed and clipped for $16 \mathrm{~d}$. per fcore.

Befides the above mentioned work, many extra jobs are done by the great, which is always the molt pleafant contract between mafter and man.

For the price of provifions, taken before the late extraordinay rife, fee under the head of Markets.

This fcale of wages, and price of labour, may do for a man with only one or two children, but if he has more, it is evidently not fufficient, according to the prefent rate of provifions; for in the houfes of induftry, where every fpecies of œconomy is obferved, and where they have the advantage of boarding a great number together, and buying in their provifions at bent hand, the mere

$$
\mathrm{X}_{2}
$$

eating 
eating and drinking, alone, cols $18 \mathrm{~d}$. per head, which I have authority to ftate from sir Edmund Bacon, who thewed mc the account of their expenditure, and whofe attention to thefe inflitutions, is diftinguifhed by every fpecies of humanity and benevolence that is in his power to beflow. Therefore, as a cottager muft purchafe his comforts at a great difcount, it is clear, that when his family exceeds what I ftate, he mult have confiderable help, let him be ever fo indufrious. See a word more upon this fubject under the head of Gencral Obfervations.

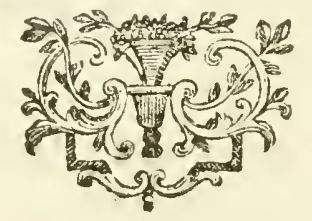




\section{$\mathcal{N} \bigcirc \mathbb{T} \mathbb{E}$.}

(a) Mr. Howlett remarks-" Thus to fix the price of "threfhing, appears extremely abfurd; a labourer in threfh‘: ing wheat of the produce of 1793 , could make better earu“ ings at $2 \mathrm{~s}$. a quarter, than in threfhing that of 1792 , at "2s. 6d. and of barley in 1793 , at is. a quarter, than in 1792, " at $15 \mathrm{~d}$. or, perhaps, even $18 \mathrm{~d}$. - It would furely have been " a molt ufeful information to have been told, what has becn "the increale of the price of labour during the laft forty or "fifty years, and what the alvance in the price of neceffary "provifions. This done, for every county, would be of the " higheft importance. This has been done for a confidera" ble part of Scotland, in Sir John Sinclair's Statifical Ac" count, and it throws more light on the caufe of the increafe " of the Englifh poor rates, than any thing I have yet met "with."

I apprehend, the general increafe of labour, within the period Mr. Howlett fpeaks of, does not excesd 25 per cent.but that the average price of fuch provifions, as affect the labourer, have increafed, at leaft, 60 per cent. but this is not all, for the fources of the market, which ufed to feed him, are, in a great meafurc, cut off, fince the fy,ftem of large farros has been fo much encouraged: but it may not be improper to look ftill a little farther back, in order more fully to latisfy ourfelves, that the wages of the labourer in ajriculture, have not kept pace witl the increafed price of provifions-on this occafion, I beg leave to recommend Billop Ilectwood's Chronicon Preciufum, to Mr. Howlett's perufal. 


\section{Settina XXVI.}

\section{FAIRS AND MARKETS.}

\section{CHE fereral fairs are held at the following places and times:}

Acle, Midfummer-Day

Alburgh, Junc 21

Attleborough, Th. bef. Eaf. Thurfoy, bef. Whit. Sun. and Anguit i 5

Aylefham, March 23, laft Tuefdas in Sept.-OAt. 6.

Baston, it Monday in Auguit, November 30

Banliam, Ja1. 22

Bunham, July 25

Britton, May 26

Broomhili, July 7

Jurnham, Falt. Mon. \&z Aug.I

Caltleacre, April \& 8 , July 25

Cawfon, Feb 1, \& latt Wed. in Apriland Aug. Sbeep Sb.

Cley, laft Fiday in July

Coltifhall, Whit-Monday

Creffingham Magna, Aug. I2

Cromer, Whit-Mondà

Dereham, Feb. 3, July 3, 4, and $T h$. before Sept. 29

Dis, November 8

Downham, May 8, Nov. I3.

Jilnham, April 5

St. Faith's, Oetober 17

Feltwell, Norember 20

Fincluam, March 3

Eorncet, Sept. II
Foulham, zf Tuefday in May Fretenham, ift Mon. in Apr. Fring, May uo, November 30 Gaynock, June 11, at Gaywood, anil Odt. 17, kept ąt Linn Cuftom-houfe key Giling, juiy 25

Giefing inall, Decemher 6

Harlefton, July 5 , Sept. 9, \& Nov, 28,1 month, for Scots cattle

Harling Eaft, May 4, Sept. I6 (Sbeep Storu), Oet. 24

Harpley, July 24

Hempnall, Whit-Monday, December iI

Hempton, Whit-Tuefiay, Nov. 22

Heacham, Auguf 3

Hingh $\mathrm{m}$, March 7, WhitTuefday, Octoher z

Hockbain, Eatter Monday

Hockwold, July 25

Holt, April 25 , November 25

Horning, Mon, after Aug. 2

Ingliam, Mon. after Whit.. Monday

Kenuinghall, July is, Sept. 30 (Shcep Show)

Kipton-a m, 
Kipion afh (Steep Showu) Sept. 4

Jitcham, November I

Loddon, Ealter Monday and Monday after Nov. 22

Ludham, Thurf.after Whitf. week

Lynn, (Mart) Feb. I + , lafts 8 days.-October 16

Ling, November 21

Maffingtian, Tuefday before Ealter, November 8

Miattiliall, Tuefday before Holy Thurflay.

Miethwold, April 25

New Buckenbam, laft Satur. in May, \& November 22

Northwaltham, Holy 'Thurf. Northwald, Nov. 30

Nor...ich, Day bet. Good Fri. Do. (Eifbop Eritge) Ealter Montay and Tueflay

Do. (Do.) Whit-M. \& Tu. Oxburgh, March 25

Pulliam St. Nary, 3d Thurf. in Nisy

Reepham, June 29

Ruithan, May 17 , Oetober 13

Scule, Ealter Tuefday

Scotow, Ditto

shouldham, Sept. 19, O\{. 1o.

Southrepps, July $=5$

Sprowflon(Magdalein), Aug.2

Stioke, December 6

Storibialge, Sat. after WhitSundiyy

Swaff́ hatll, May 12 , July z-1

November 3 (Sheep Stionus)

Thetfori, May i 4, Auguit 2, September 25

Wallingh:ml, Whit Monday

Watton, July 10 , October 10 , Noveruber $\mathrm{s}$

Weafenham, Jan. 25

Worlted, Mily 12

VYymondiam, Feb. 2, and NIay $6,0 . S$.

Yarmuuth, March 28 k 2 .

Many of thefe are much upon the decline, but fome of them rather increafing.

The greateft of thefe, for cattle, are St. Faith's, Harlefton, and Hempton Green; to which are brought a vaft number of Scotch and Irifh catile.

The greateft for Theep, are Kipton-alh, Cawnon, and Harlefton.

\section{The Markels,}

As far as relates to the pitching of corn, are every where dropt, and the whole trade is carricd on by fample, which is greatly againft the labourcr, 
artificer, and little tradefman, as it has a tendency to throw the corn into the channels of monopoly, and I do not think a better thing could be done for the community, than that of giving all poffible encouragement to public fairs and markets; for, among other good effects that might refult from them, I am of opinion, it would tend more than any thing, to check the increale of large farms, as I have before ventured to oblerve.

As to the markets for other provifions, fuch as poultry, butcher's meat, and vegetables, I do not think any part of England can exceed that of Norwich, nor are thofe of Lynn and Yarmouth inferior, except as to fize-but of late, the prices of all articles are very much increafed, even without having any reference to the very late exorbitant rife, but merely fating the difference between twenty years fince and lan year.

Butter was then $7 \mathrm{~d}$. a pint, of $20 \mathrm{oz}$. - laft year it was is.-cheefe is increafed from $3 \mathrm{~d}$. per $1 b$. to 6d.-poultry and eggs in the fame proportionpork and butcher's meat from $3 \mathrm{~d}$. per lb. to $5 \mathrm{~d}$ meal from Is. to $1 \mathrm{~s} .6 \mathrm{~d}$. per ftone, of $14 \mathrm{lb}$.-malt from 11. 12s. to 21 . 8s. per quarter-vegetables very reafunable, and in much greater abundance than formerly-milk at $6 \mathrm{~d}$. a gallon, but very little to be had-wild fowl plenty and reafonable, in hard feafons. 
Fith, confidering it as a maritime county, neither regularly fupplied or cheap. In the rivers there is good pike and tench. From the fea, the beft filh are lubfers and foles, and fometimes the cod is pretty good; herrings very good; whitings rather fmall; oyfters very large, but not good in proportion; herrings right good and cheap, and, it is prefumed, the valuable trade they afford might be greatly improved and extended, by checking the encroachment of the Dutch upon the coaf, who have for a feries of years run away with the adrantages which ought to have attached to our own eaftern fea-ports, particularly to Yarmouth.

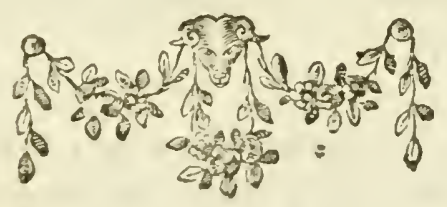




\section{Section XXVII.}

\section{STATE OF THE POOOR。}

I $\mathrm{HE}$ poor-rates have increafed in this county in a full proportion to others, and with a view of ftopping this increafe, feveral houfes of induftry (a) have been eftablifhed; but they are grievous things in the eyes of the poor, and I am afraid, are not found to anfwer the end that was expected from them. I know of no law that can enforce indufry; it may be encouraged, and great good will refult from it; but it never can be effected by compulfion (b).

There are two principles which fhould be kept alive, as much as poffible, in the minds of the poor-pride and thame: the former will lead them to the attainment of comfort by honeft means; and the latter will keep them from becoming burthenfome to their neighbours. But many of the modern plans, for making provifions for them, have tended to deftroy thefe principles (c). 
A man born to no inheritance, who affiduoufly devotes his whole life to labour, when nature declines, has as great a claim upon the neighbourhood, where the labour of his youth has been devoted, as the worn out foldier or failor has to Chelfea or Greenwich; and this reward ought to be as honourable, as it is comfortable, and not to be adminiftered in a way that is repugnant to that natural love of rational freedom which every human mind fympathizes in the enjoyment of.Such a man, as I have here characterized, ought to be diftinguifhed from the lazy and profligate wretch, who has feldom worked but by force. The one ought not to be crowded into the fame habitation with the other; but in houfes of induftry there can be no diftinction $(d)$.

The focial clubs for mutual relief, which are prevalent in many parts of the weft of England, are highly commendable; and, perhaps, as well worth the attention of the Board of Agriculture, as any object they can take up. If a little encouragement could be given to thefe laudable focieties, which are now fanctioned by law, and proper places of fecurity could be eftablifhed for their little funds, it would tend very much to encourage the poor to ftruggle with their difficultics; and it would be confiftent with found policy, as well as humanity, in the rich and opulent, to add little donations to the poor man's neft egg, on thefe occafions. 
cafions. Earl Harcourt's example, at Nuncham, in Oxfordfire, is well deferving imitation; if a poor man puts a penny into the locial box, he puts in another; if a farmer or tradefman contributes a fhiling, he adds another; and by this means his lordfhip's eftate is kept in high credit, the poor-rates are low, and the fpirit of the peafantry unbroken; which is the great thing that ought to be aimed at, and unlefs fome encouragement of this fort be given, it is impoffible that the labourer in hufbandry can, when he has a family, procure his daily bread, with his prefent daily wages.

There is one thing which is incumbent on all great farmers to do, and that is, to provide comfortable cottages for two or three of thcir molt indufrious labourers, and to lay two or three acres of grafs land to each, to enable fuch labourer to keep a cow (e) and a pig-fuch a man is always a faithful fervant to the farmer who employs him: he has a ftake in the common intereft of the country, and is never prompt to riot, in times of fedition, like the man who has nothing to lofe; on the contrary, he is a flrong link in the chain of national fecurity.

There are but few great farmers, however, inclined to accommodate cottagers with thefe little portions of land, and when they do let them any, 
it is generally at double the rent they give for it. But I am perluaded, that if there were a certain number of cottages, of this defcription, in proportion to the fize of the eflates, and they were accommodated in this manner, and thofe places were beflowed as a reward to labourers of particular good conduct, it would do wonders towards the reduction of the rates, and the prefervation of order; for I have been witnefs to feveral ftriking proofs of this, in two or three labourers, who have been thus faroured, whofe attachment to their malters was exemplary, as they were not only fucady in themfelves, but by their example kcpt others from ruming into cxcels. There camot well be too many of thefe places attached to large farms; they would be the molt prolific cradles of the beft furt of population.

There is another thing which it is incumbent on all nccupicrs of land to do, which is, to fupply their own labourers with wheat at a moderate price-when the price in the market is high and oppreffre to them $(f)$. It is but reafonable, that the human fervant hould fare as well as the animal lervant: a farmer docs not give his horfe a lefs quantity of oats, becaufe they are dear, nor is it icafon ble that the plough-man, or threfher in his barn, fhould have lefs for his penny', becaufe the mafler gets a great price; but I do not main to fay this thould be cxtended to manufacturers, becilule 
caufe they are in general better paid than labourers in agriculture, and have not fo immediate a claim upon the land, as the workmen in the vineyard.

If one thing, in aid of what I have taken the liberty to fuggeft, could be eftablithed, it would, perhaps, go near to remedy all grievances; and, in a great mealure, fet afide the neceffity of the poor laws, and this would be the adoption of fomething like Mr. Ackland's fcheme $(g)$ of taxing labour for its own fupport, by levying from the young and lufty, a penny to be put out upon accumulated interen, for the advantage of the old and decrepid. Age and infirmity would then dip its hand into the purfe it had helped to fill; honeft pride would be preferved, induftry encouraged, and the latter part of a poor man's life would ter. minate in comfort $(h)$. 


\section{$\mathcal{N} \mathbb{O} \mathbb{E} S$.}

(c) From Sir Thomas Beevor:- "Thefe eftablifhments, "militating with every principle of humanity and political " interel, and not unfrequently with thofe of morality, can" not be too often, or too much reprobated, and though this " may not feem the proper place to enter into any detail of " the fubject, yet, perhaps, it may not be quite foreign to the " purpofe of this view, (omitting the article of inhumanity", " which muft arreft the obfervation of every one who knows " the powers and management of them) to point out the in" jury the public fuftains, from thefe inftitutions, in the lofs " of labour and corruption of manners.-With refpect to the " firft, it appears, that in the year, from $178_{3}$ to 178, , the " number of paupers in the workhoules at Norwich was " 1301 , the earnings of whom, in the year, were only 10291 . " sos. 8d. and in that from 1785 to 1786 the number of " paupers was 1600 , the earnings 14251 . 12s. or $17 \mathrm{~s} .8 \mathrm{~d}$. per " head, per ann. not quite $\frac{3}{4} d$. per diem-and in the houfe " of induftry at Wicklewood, the earnings of the paupers are "s ufually about i5s. per head, per ann. little more than $\frac{1}{2} \mathrm{~d}$. per "head, per diem-and if it be allowed, that one-half (which " is more than the due proportion) be incapable of work, " the refult will be only double the above pitiful fums : the " reafor of thofe accounts being taken from the fpecified " years, is folely becaufe at that time it was made the fubje\& "r of enquiry by the writer of thefe remarks. As nothing " ftimulates to induftry fo much as intereft, and the man who " works for another, will ever contrive to do as litele as pof-r fible, there are but few hopes of amendment in this point- 
" to what a fet of ufelefs beings are fuch numbers thus re" duced. In the article of morality, it is to be wifhed, that " the truth of the following fact would be doubted, but the " account has been publifhed and never contradicted: that, " upon an enquiry made into the ftate of the workhoufes at " Norwich, a few years ago, there were found three or four " perfons, of different fexes, lodged under the fame blanket, " men, women, and children. promifcuoully affociating to" gether. Nany other fimilar inftances can be produced, " but thefe, and the other evils attendant on thefe eftablifh" ments, will probably be the fubject of a future publication."

(b) From Mr. James:- "If poor houfes are grievous things " in the eycs of the poor, I am apprehenfive, it proceeds only " from their mifinanagement. Extreme poor, fuch as entitles " a man to affiftance, proceeds from feveral caufes, from in" ability for labour, through ficknefs or age, unwillingnefs, " through an idle profligate difpofition, and, fometimes, from " the want of opportunity: it never was intended that thefe " three claffes thould be blended together; if I am not mif" taken, poor houfes were inftituted with a view to be an afy"" lum for helplefs infancy and age, to furnith means of reco" very to the fick, and employment to thofe who are willing to "work, but, from want of opportunity, are unable to fup" port themfelves-but for what reafon thould the profligate " and indolent be introduced, furely they are not fit inhabi" tants for an houfe of induftry, the houfe of correction " would, I conceire, bc, by far, a more proper place; at " any rate, they thould be kept apart, for as a general infec" tion is ever occafioned by a particular one, fo one licen" tious character is often the means of fubftituting diforder " and confufion, in the room of order and regularity. Com"pulfion is not congenial to the mind of man; encourage" ment ought ever to be preferred to force; this I advance " as a general rule, but, like every other, it is not without its "exception, for I mult confels there are fome which are 
" never to be overcome, but by the latter. As to the poor " dinliking them, if our author does not mean the aged and the " difabled, is rather an argument in their favour, than other"wife, for if their fituations were rendered too comfortable, " their effect might operate very differently to what was in" tended, by encouraging that very lazinefs which the inft" tutors were in hopes of deftroying: as it is, their dinlike " may produce, firt, a defire of providing for themfelves, " and a difpofition to embrace the firft opportunity, which " by chance or enquiry they may happen to meet with. If "the aged and infirm are diffatisfied, humanity dietates to us " to lofe no time in enquiring into the caufes of their dinike, " and, if properly founded, to relieve and redrefs them."

(c) From Mr. Howlett:-" The remark in this paffage is " indubitably juf, and deferves the moft attentive confidera"tion."

(d) From Mr. Howlett likewife; - "This is a moft power"ful objection to houfes of induftry, and there are many " more of equal force, and one cannot but be aftonifhed at "the daily inereafe of their number."

(e) From Mr. Dann:- "Certainly it is highly laudabie and "politic for farmers to encourage and reward labourers of "good conduct, but, in preference to furnihing them with " means of keeping a cow or pigs, I would recommend giving "them fkimmed milk, and letting them have a proportion of "pork and wheat, according to the number of their family, "below the market price, and, indeed, fuch is iny practice. "When they have a cow or pigs, it is too often feen, that it "leads them to difhonef means, to fupport them; fuch, how"ever, lias very often been the cafe in my neighbourhood; "but coinfortab!e cottages, with proper gardens, I always "wifin to liee them have." 
From Mr. Boys:-" If farmers, in genera!, were to ac" commodate their labourers with two acres of land, a cow, "s and two or three pigs, they would probably have more difof ficulty in getting their hard work done-as the cow, land, of \&c. would enable them to live with lefs earnings.

(f) From Mr. Howlett:- "This indulgence to the labour" er is, undoubtedly", a matter of kindnefs and humanity in" "the mafter, but it feems by no means incumbent upon him, " or if it be, it is equally fo upon the employers of manufac"turers; and if this abatement of price be requilite in one " article, upon fimilar occafions, it muft be equally neceffary " in all, and this would, in the end, be the fame as an ad" vance of wages, which furely ought not to depend on the " choice or caprice of individuals, but be under the infpection " and regulation of the public, as expediency might require."

(g) From Mr. Howlett likewife:-" Mr. Ackland's plan, " in my apprehenfion, is, by much, the beft that has yet been " propofed to the leginature. If put in execution, it would " probably be attended with fome beneficial confequences, " though certainly neither to the degree nor the extent here “intimated. It makes no provifion for natural weaknefs " and debility of conflitution, for occafional deficiency or " fcarcity of employment, for feverity of feafons, and varia" tion in the price of provifions; befides that, the whole goes " upon the fundamental error, that the poffible earnings of "the poor are univerfally adequate to their neceffities."

From Mr. Fox:-" It gives me much pleafure to per"ceive the ideas I have given on this fubject, (in my Note Ir. " on my fecond perufal of the Report for Gloucefterfhire) 65 fo appofitely fupported by the author."

(h) From Mr. James:-"Some fuch plan would, no doubt, "be very beneficial, but the prefent price of labour will by 
si no means admit of this trifling deduction, therefore an alte" ration muft take place previous to its adoption; in the inte"rim, I would recommend a fund to be eftablifhed, by means " of the rich, for this purpole. The inequality of the poor"rates has long bcen a fubject of complaint-fuppole all the " poor were to be confolidated, and every parilh, by means " of overfeers, chofen annually from among them, but fub" ject to the controul of fome fuperior board, was to take "into its care their own refpectively-the means of their " mainterance to be furnifhed by Government, who, in or"der to be enabled, might impore a fmall addition to the s: land-tax, or a per centage upon the affeffed taxes."

Upon thefe different remarks I have but little to fay; Sir Thomas's firft obfervation appears to me manly and juft, but I could have withed, that in his fecond remark, he had not been of the fame opinion with Mr. Dann. It feems to me a bad argument, that a man is to have a comfort with-held from flim, left it hould have a tendency to make him difhoneft.We may as well ray, that they ought not to have a chimncy in their cottage, left it fhould be an inducemeut to them to fteal wood to burn in it.

Mr. Boys's remark is of the fame caft: he is not willing to allow a poor man the greateft bleffing that can be given him, left the farmer fhould be liable to fuftain fome little inconvenience by it.

MI. Howlett is for confidering this as an indulgence to the labourer, if it be granted, and by no means incumbent on the great farmer: but in this I muft totally difagrec with him, for I llink it is a politive duty, which the law of humanity and the duty of a chrifian frongly prompt him to comply with." 


\section{Section XXVIII.}

\section{REPREHENSIBLE PRAंCTICES。}

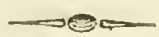

T

HOUGH I have, in this Report, given great commendation to many practices of hufbandry, which I think deferve imitation, it is incumbent on me, for the fake of juflice, to take notice of a few things, which, in my opinion, are reprehenfible. The harreft, a very important branch of hufbandry, is gathered in a very flovenly manner: women and boys are feldom employed in any part of it. A certain number of men are provided according to the number of acres of corn; in the beft parts of the county, ten or twelve acres is the allowance to a man; in the light parts, fifteen or fixteen acres. The man is boarded extremely well, and his allowance in money is from two guineas to fifty fhillings, whether the harven be long or thort. The firft thing the farmer aims at, is to time the beginning of his harven, fo that his corn may follow in fuccefion, that no interval or paufe may take place; as the boarding of his men is at- 
tended with great expence, and, therefore, the fooner he can get the work through, the lefs it will colt him in provifions. This narrow idea often cofts him nearly a tenth part of the value of his crop, for he feldom begins reming his wheat fo foon, by ten days or a fortnight, as he ought, though wheat is always the better for being cut rather early. It often flands till the ears turn down in an inverted fate, and till it is fo ripe and brittle, that when there happens to be a brik wind, it is no uncommon thing to fee four or five bufinels of wheat whipt out and lof, and lometimes a ouarter of oats $(a)$.

The barley is always carried from the fwarth, fo that they never begin to carry till late in the day; and no part of the ground is raked till afterivards; fo that a vaft deal of corn is trodden out. After the bulk of it is carried, the piece is drag-raked, by men, with iron teeth drags; or by a drag faftened to a pair of wheels, and drawn by a horfe. The latter is the beft practice of the two, though they are both bad; for the rakings are fo mixt with grit and duft, that the corn is of an inferior quality to the other. It cannot be doubted but the protice of moft other countries is to be preferred to what is obferved here.

In the firft place, the hufband is feeding with unafual luxury, while the wife and childien are 
flarving. It would certainly be more comfortable if they undertook the reaping and mowing of a ccrtain number of acres, in which cafe, the man might work with his family, and his wife and children would carn fomething confiderable, not only in the reaping part, but in the cocking and raking the lent grain, which would enable them to eat a comfortable morfel together. There would not, if this were the cafe, be half fo much corn thelled and loft; and the barley, in a wet featon, would be better preferved, and admit of being carried much earlier in the morning from the cock, than it can from the fwarth (b).

Stacking is another thing which is very ill done here, particularly wheat ftacks, though they are fomewhat improved too in making them, of latc ycars; but they run them up in a long rickety form, without fymmetry, and feldom fet them upon liaddles, to preferve the corn from vermin. A nothervery bad practice relates to their fonces, No farmers raife a white-thorn hedge fooner, or defroy it fo foon; every other time of cutting hedges of this fort, they are buck-ftalled, as it is called, which is cutting the whole hedge off at about three feet from the ground, which is an irreparable injury to it, by checking the growth, and making it hollow at the bottom. And as to other thorns and ftubb-wood, they are apt to cut them as their immediate wants require, at all feafons of 
the year, and to leave the fool in a jagged fate, fo as to admit the wet into it, which caufes it to decay. On the contrary, wood fhould never be cut but in the winter feafon, and fhould be cut upivards to a fmooth point, and as clofe to the flools as poffible, and then it will fhoot again with more vigour.

I have taken the liberty to point out thefe practices, as difcreditable to this county, but I do not know of any other which are very reprehenfible, but there is one, which is prevalent in fome other counties, which has a very hurtful tendency, I mean that of burn-baking, upon which, I trun, I fhall not be confidered as going much out of my way, if I exprefs my fentiments upon it with freedom, in this place; I will frankly avow I do it with the double view of preventing its introduction here, and checking its progrefs elfewhere; for though the crops obtained from it, are fuch as to produce a temporary advantage to the occupier, it is a mortgage without redemption upon the fee-fimple of the land, by recucing the flanle, and depriving the foil of it naturai graflics. The better way is to fcale-plough the furface, and alterwards bury the roots and give them time to rot, and land, thus ufed, is generally very fertile and kind. Burn-baking is, in my opinion, a very pernicious practice, and I truft will foon be exploded. If it is any where to be allowed, it is upon the coarfe fenny parts of Lincolufhire-unn a thatlow 
Shallow foil it is infufferable, becaufe it tends to leifen the depth of the foil ; for though the advocates for it:will fay, that earth cannot be reduced, yet when we confider that the furface or rind of land, (which by this practice is pared off about two inches in thicknefs) is nothing but the relicks of putrified plants, which afford the beft aliment to renewcd vegetation, it certainly does, in this fenfe, admit of dimunition, and befides weakening the foil, it unqueftionably defroys all feeds of the beft graffes which nature has depofited in the furface of the earth, which is very obvious from this land being lefs favourable to grafs, for a feries of years, after it is burnt than before. This pernicious practice mult have had its rife from lazinefs, being an eafier way to get rid of a coarfe rough fwarth, by this means, than by fuch modes of culture, as would have for their object, the reducing it to a rotten flate; it muft therefore be expected, that all temporary occupiers will continue advocates for it, but it is prefumed, that all owners of eftates, looking forward to a more permanent interen, will do all in their power to difcoum. rage it.

Upon a perufal of the Agricultural Reports, lately publifhed, I was much plealed to find this practice condemned by a very confiderable majority of the reporters. Mr. Davis obferves, "that " it is a maxim often quoted in Wilts, that how- 
" ever good the hufbandry may be for fathers, it "is ruin to fons."

Mr. Fox, for Monmouthfhire, fays, "that where "the foil is thin, it is injurious-that it may give " a crop for a year or two, but after, will give "very little produce but that of hungry weeds."

Mr. Stone, for Lincolnfhire, confirms the obfervations of the latter, by remarking, that where the practice has prevailed, "evident marks remain of "the injury the land has fuftained by it."

Mr. Lowe, for Nottingham hire, obferves, that "lands, in Norwall lordhip, have been entirely " Spoiled by it." Mr. Calvert, in the Appendix to the fame county, obferves, "that in many in"ftances he has known a barrennefs enfue, which " a long feries of years has not been fufficient to "remedy."

Mr. Holt, for Lancafhire, fays, that "it has "been too much practifed, and its deftructive "effects are but too apparent upon many farms, "where it has been frequently repcated."

Mr. Tuke, for the North Riding of Yorkfhire, ftates an experiment made between one part of a field of old grafs-land broke up, in a proper manner, with the plough, and another part burn-
A a
baked, 
baked, the refult of which was, "that the crops "upon the pared and burnt land, after the firf " two or three years, kept gradually growing worfe, " and upun the ploughed part, the crops, for fome " years, grew better, and afterwards were vifibly "fuperior to the pared and burnt land."

Mr. Vancouver, for Cambridgefhire, obferves, that "in the King's, the Qucen's, and other coun" ties in Ireland, where paring and burning the " thin high lands have been unfortunately prac"tifed, extenfive and naturally fruitrul tracts have " been reduced to the loweft and moft exhaufed " nate of barrenneis and poverty, and as the like " effects mult on a certainty, under fimilar circum"ftances, foilow the lame practice in this kingdom, " is it not eafy to comprehend the reafoning of " thofe perfons, whofe judgment leads to the gene" ral recommendation of fo pernicious a fyfem."

After fuch a chain of reprehenfion, from fo many refpectable found agriculturifs, I was not a little furprized at Mr. Arthur l'oung's coming forward, in the Eamp?hire Appendix, not only with a fanguine recommendation of this reprobated fyftem, but with a fout of confure upon fuch of the reporters as are of a different opinion. In another place too he has exprefied himfelf with great confidence upon this fubjeci, but whether to his crecit or difcredit, I will not take upon me 
to determine, but as Mr. Young's reafoning may have a tendency to increafe what I conceive to be a real cvil, I mean the breaking up of the maiden downs, which arc the glory of the weftern counties, and one of the greateft fupports of the woollen manufactory, I hope I fhall not be confidered as going out of my way, in making a Thort remark upon it.

The increafe of rent, upon land thus broken up and pafied through this ordeal trial, is no decifive proof, that the practice is advantageous, even in that point of riew, for it is evident that reducing the quantity of down mult reduce the number of Theep, and confequently leffen the value of the old tillage, by robbing it of the fold, which is its beft fupport; fo that two certain advantages are facrificed for one, and that, perhaps, not permanent. In fhort, without a due proportion of old fivard, a flock cannot, all the year, be kept in health; artificial grafles, though good in their kinds, will not alone anfwer the purpofe required; this every farmer of experience knows, and it is not in Hamplhire alone where the lofs of this old turf has been grievoully felt, but in many parts of this county, particularly in the neighbourhood of Thetford, where the breaking up of fo inuch of the heath land, has fo far contracted the fhecp-walks, that the flocks fufain an irreparable injury from it. So far thefe practices attach to farmers; but there is 
one more, which I cannot pafs over without now tice, which applics to the poor, I mean that fcandalous cuftom of cutting up the commons for fuel, without any diftinction of foil: if they were to confine it merely to boggy or rough coarfe parts, it would be lefs reprehenfible, for I will allow the argument of neceffity to be very frong; but to cut them up, as they now do, indifcriminately, frequently paring off green fward, the herbage of which is worth twenty thillings an acre, is unpardonable; for independent of their not having a fhadow of right to break up the foil, they, in fact, deftroy their own intereft in the mouthage, in which, perhaps, their right cannot be difputed. I hope, therefore, that this caution may have fome good effeet in recommending it to the poor, to be more modeft in this practice in future, and not to do it without leave fir? obtained from the lord of the manor, and, at the fame time, be a hint to the latter to look into this abufe, and endeavour to flop it in time. 


\section{$\mathcal{N} O \mathbb{T} \mathbb{E}$}

(a) From Mr. Wagnaff:- "s The remark on the late begins ning of harveft, and the confequent lofs from delay, moft " literally did apply fome twenty or fifteen years back, and " may ftill apply to many individuals now; but a requifite "reformation has already taken place with the generality of "the farmers, particularly in the vicinity of Norwich."

(b) "It may be recollected, that while the men are thus "profitably employed to earn a fum generally adequate to "their annual rent, the wives and children are gleaning the " fields, by which a provifion is made of bread for the whole "family during winter months; and a little providence before " harvelt, or a fmall dip of credit on the wages to be received "by the hufband, is an effectual bar againft ftarving-while " their focial meetings are a triumph of cmulation, and would " not be exchanged by them for any other fpecies of labour, " as, indeed, it is generally more and longer beneficial. " While cocking, or gathering the fwath, is of problemarical "preference, it is certain that the Norfolk farmer prefers "hisown mode, as raking by fome of his men, he believes "is moft to his profit."

I am much indebted to this gentleman for a great many fenfible and humane obfervations upon different parts of my Report, which, in my opinion, do him great crelic; but, in the prefent inftance, I doubt he his fi:fered himliff to be biafed by a litule provincial prejudice.-I have nu objeftion to the wonens' gleaning, provided they reap firtt; which is 
190

AGRICULTURAL SURVEY

the cafe in other counties. There is not gleaning enough for all the women and children, the latter would be alone luffcient-but this might be regulated without any prejudice to the women, who were more profitably employed, provided there was a proper difpofition in the country to that effect.

As to the focial meetings, I should think better of them, if the wife and children participated in them; but, as this now stands, we meet with nothing but drunken men, filling the public houfes for forme days after the harvest is ended.

Reflecting the barley, if Norfolk men Should fill object to its being cocked, I would advise them to gather it, at leafs, with rakes inftead of thack-forks, for the latter often leaves two bushels per acre upon the ground, and the difference in the expense is only $2 \mathrm{~d}$. per acre. 


\section{Section XXIX.}

\section{GENERAL OBSERVATIONS.}

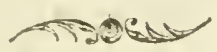

$\pi$

$N$ this Report, it has been my aim to give a faithful account of the Norfolk hufbandry, and fuch other cuftoms as are neceflarily connected with it, without extenuation or exaggeration; and the intelligent farmer, in other parts, will be under no diffculty in determining which parts to aciopt, and which to rejes.

In the perufal of a treatife of this kind, it is incumbent on the reader to lay afide all prejudice, and fulfer his mind to be open to convictionotherwife, I fhall have written, and he will read, in vain. I fhould not have thought it neceflary to introduce this caution, if it were not almol generally allowed, that hufbandmen are more obftnatcly atached to old practices, let them be ever fo bad, than any uther deleription of $\mathrm{men}$, and are confequently arertis to the introduction of any thing new, Ict it come cver fo well recommended; 
at the fame time, it is highly proper to be careful againft adopting the vifionary recommendations of modern theorifts, who, upon hypothefes of their cwn, hold up wild fyftems of delufion, which are apt to miflead the credulous and do great injury.

True judgment feems to lie in felecting fuch objects for imitation, as are either the refult of well attened experiments, or that come from fuch refpectable authority as cannot be doubted.

In the profperity of agriculture, there are three perfons who have a natural tye upon each other: the gentleman of landed intereft-the farmerand the labcurer. Their degrees of intereft are different, but their connection muft be permanent, as they cannot fubfift without the aid of each other: Protection is due from the firfhumanity from the fecond-and obedience from the third. Sound policy difates a due obfervance of this mutual obigation, and the prefervation of a proportionate and jutt fcale in refpect. to every thing which mutually affects the parties: a departure from this, will, in the firf inftance, prove very detrimental to one of them, and cannot ultimately be of any advantage to the others.

Admitting this, as every impartial man mult, and comparing the advanced price of provifions, 
with the prefent rate of wages, and the price of labour, the caufe of the increafe upon the poor-rates muft be obvious. I would, therefore, advife every gentleman in the commiffion of the peace, carefully to perufe a book I have before recommended in this work, namely, Fleetwood's Chronicon Preciofum, which will thew him the proportions which were obferved at that time, and likewife to advert. to two particular acts of parliament, framed by the wifdom of our anceltors, viz, the $5^{\text {th }}$ of Elizabcth, chapter iv, and the 1 it of James, chapter vi; where fufficient power is given to regulate this important bufinefs.

Every farmer I would advife, to confider the labourer not as an incumbrance upon him, but as effentially neceffary to carry on his bufinels, without whom he could not live or fupport his own family; but the prefent weak policy has arifen from a mifconccption of the utility and real importance of the labourer to fociety. No farmer will flight his horle, or give hin the lcls hay or corn for its being dear, if he did, he would expect the animal to decline in condition. - Why then fhould the human fervant be lefs attended to? He is, undoubtedly, the firft fincw that puts the labour of the farm in motion, and without which it cannot be carried on: if, therefore, his full carnings will not keep him, it is a duty incumbent on his snafer, to let him have a fufficiency of corn, for his own family, at the fame rate or price by which $\mathrm{B} \mathrm{b}$ 
he is paid for his labour, and not to fuffer the fpirit of a poor man, of this defcription, to be broken.

The force of this argument is grounded in my heart, and $I$ hope it will ftrike thofe with conviction, who have power, in their different ftations, to adminifter the comfort I recommend-and that no difpaffionate perfon will blame me, for thus ftanding forth-the fteady friend of the helplefs.

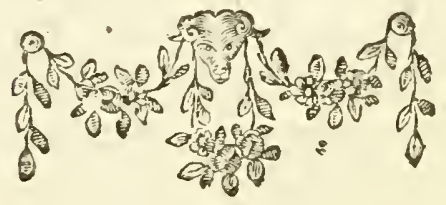




\section{$A \mathbb{P} \mathbb{E} \mathbb{N} \mathbb{X}$}

\section{On the CULTURE of POTATOES.}

Letter from Sir MORDAUNT MARTIN, Bart. to

Sir JOHN SiNCLAIR, Bart. dated Burnham, 7 th MARCH, 1795 .

SIR,

II $N$ confequence of the circular "Hints refpecting the Culture of Potatocs," I take the liberty of addreffing you, in favour of a fort I do not find named in that paper-I mean the Kentifh feedling. I was originally obliged to Sir Thomas Beevor for my ftock; they have never yct exhibited any curl, and, I think, I may fafely affert, that they have cvery feafon produced double the quantity of the Champion. I do not prefer them as dainties for the table, but, perhaps, their infipidity and perfeet white mealinefs render them the moft defirable of any for the purpofe of making bread. If they have not already been tried, and difapproved by the Board I hould be proud of the honour of fending a few, loy way of fpecimen, wherever you may favour me with permiftion to direct them.

My ftock is not many bufhels, luaving only preferved the fort with a vicw of fupplying the ncighhouring cottagers for their gardens. I feel no fmall fatisfadion in having taken 
fome pains to introduce, by example, the fieid culturc of potatoes, in hopes, that what the poor might confume, would be no more miffed than the turnips, which, I believe, few farmers grudge them; but I fear there are many formidablc objections, befides the infurmountable one of the fhallow ftaple of our dry foil.

One excellent farmer, who is a man of a very liberal mind, (Mr. Overman, of Burnham Deepdale,) acknowledges, that on his firtt trial, he had more wheat per acre, where his potatoes grew, than on the reft of the field : but the impoffibility of getting a large fpace of ground eleared in time to fow wheat, on account of the gleaning, determined him not to repeat his experiment.

The wire-worms feem to be an increafing evil in our crops which follow grafs, efpecially faint-foin, and I have, in two inftances, found potatoes increafe them to a great degree.

Another objection with me is, that when I fed my cows with potatoes, they were all fo tender footed, as to be hardly able to walk from the yard to an adjoining clofe in which I threw them: this I attributed to their treading in the dung formed by the potatoes, as they foon recovered when they ceafed to eat them.

I fincerely hope the laudable endeavours of the Board of Agriculture, may prevent the apprehended want of bread corn, by promoting the growth of early potatoes; but I have been informed, that in Pruffia, the ufe of potatoes is prohibited till a fixed time in the autumn, as it is found that the earlier ufe of them occafions the bloody-fux-the difference of climate may poffibly render this precaution unneceffary here, but you will, I hope, attribute my mentioning it to its truc motive-a defire of preventing or finding a remedy for any inconvenieuce which may attend an object fo apparently defirable, as the general culture of potatoes. 
Upon Improving the Breed of Catile.

LETter from Mr. OVERMAN, to Sir JOHN SiNCLAIR, Bart. Dated BurNiam DEEDALE, $15^{\text {th }}$ AUg. I793.

\section{SIR,}

As the purfuit of agriculture is the path of life allotted to my thare, I cannot be inattentive to any undertaking which may ferve to forward fo great a national object, more efpecially, when I fee the inveftigation of it committed to gentlemen equally known for their extenfive knowledge, and the bene. volence of their intentions-the moft beneficial confequences mult of courfe follow.

I beg to affure the Board of Agricutture, that I by no means want inclination to contributc any information, in my power, toward forwarding the great work they are engaged in; but I much fear, at the fane time that the partiality of fome unknown friend has over-rated both my abilities and my experience in hufbandry; the latter of which has becn exercifed only upon a very narrow fcale, and, were it other. wife, the attention neceffary to the conducting my own bufi. nefs, does fo far engrofs my time, as to allow very little avo. cation from my main purfuit.

I am of opinion, notwithfanding the many modern improvements which we boaft of, that luubandry, in general, is Rill in its infancy, and that the knowledge of cattle is more fo.

The county of Norfolk produces abundant proofs, tirat bones and offal are the produce of a lagge purtiun of tixe luelt herbage of this county. 
Much praife is due to the endeavours of Thomas Williarn Cokc, Efq. M. P. to introduce an improved breed, both of fheep and ncat cattle; but we do not fee that his example has been followed, as yet, in the degree which it certainly claims. Innovations, of any kind, arc, to men of uninformed minds, reconciled with difficulty, and to wear out rooted prejudices, requires great length of time.

As I learn, from the beft information, that the inveftigation of the fate of hufbandry, in this county, is committed to the care of that very able and experienced agriculturift, Nathaniel Kent, Efq. I am perfuaded, that the public expectation will be fully anfwered by the report of that gentieman, but thould it prove, in the cvent, that any local circumftances have cfcaped his enquiry, within this diftrict, I fhall be ready to communicate any information in my power refpecto ing it.

I am, Sir, \&c. 


\title{
On Fatting Beasts with Oil, Bran, \& Hay.
}

LETTER FROM LORD PETRE TO SIR JOHN SINCLAIR, BART. DATED PARK-LANE, 2d APRIL, 1795.

\begin{abstract}
SIR,
T

I AM very forry that I was detained at a meeting of the Chelmir Navigation Company, till it was too late for the Board of Agriculture.
\end{abstract}

I have received the following account from the country, relative to the fatting of beats on oil and bran: it is not fo accurate as if they had been fed with a view to making a regular experiment, but fufficiently fo for gencral information.

To finifh a beaf, weighing roo itonc or more, and coming from grafs half fat, will coft, in oil, bran, and hay, 1os. per weck, and gain, at lealt, 12 fone per month, by which, at the moderate price of $4 \frac{1}{2} \mathrm{~d}$. per $1 \mathrm{~b}$, or 3 s. per ftone, the fecder will be the lofer of $6 d$. per fone; but as the $n x$ will be improved, in valuc, is. per ftonc more, than if he had not been frnifsed with oil, (on account of the encreafed quantity of fuct gained by the feeding with oil or oil-cakes) the fecder, upon the whole, is well paid for his trouble and expences.

What would be the difference between the expence of oil, or oil-cahes, I cannot pretend io fay; I am at fuch a dillance from the mills, that the carriage is very confiderable, and a jar or wo of oil is edily brought from I,ondon, which in. duces rise to prefier vil.

I remain, \&c. 


\section{On the Practice of Dibbling Wheat.}

Letter from J. B. BURROUGHes, Eso. to Sir JOHN Sinclair, Bart. Dated Burlingham, 21ft August, 1794.

SIR,

I HAD the honnur of receiving a letter from you, with your Addrefs to the Board of Agriculture inclofed, for which I beg leave to return my proper acknowledgements.

In your letter you mention Mr. Varlo's referring to me, in a paper he laid before the Board of Agriculture, refpecting fome important experiments I made in the practice of dibbling; in confequence, fome queftions are propofed to me. Permit me to obferve, Sir, it was not till the autumn of ${ }_{1792}$, I adopted this mode of fetting wheat, to any extent, therefore, cannot have made any experiments worthy to be laid before the Board; but have collected fuch information as the neighbourhood affords on the fuhject, which, with my own obferrations on the practice, I humbly fubmit to you.

Jirnt. What are the different forts of grain that can be dibbled to advantage?

atratr. Wheat, peas, barley, and oats.-Beans alfo, when grown in this neighbourhood, (which is but feldom) are dibbled.

Secont. What is the proper feafon for each, and can dibbling be done earlier and in worfe weather than when feed is fown by other procelfes?

fnswer. The weather fuitable for fowing, is the fame for dibbling.-The wheat dibbling begins the middle of September, and continues to the end of Oatober: for barley and oats 
March, and the beginning of April ; for peas, March, and as much earlier as the feafon will admit of.

Thito. What is the expence per acre, and what has been found the beft dibbling infrument;

Ritotact. Wheat is dibbled from 9 s, to ' 10 . per acre; four furrows are contained in a yard wide; two holes are dibbled in each furrow, and the holes are three inches diftant in the rows. Barley and oats at 8s, and peas at $7 \mathrm{~s}$. per acre. The infrument commonly ufed in this neighbourhood, I have taken the liberty to fend you; it is fteeled at the point, about three inches in length-the depth of the holes is about two inches. - This infrunent is ufed for all dibbling.

fourti). Ti'hat are the beft foils for dibbling, and is it found applicable on deep clayey foils?

anstert. Our lighteft foils are dibbled to advantage, and fo on, to the ftrongeft loamy foil: deep clayey foil does not abound in this neighbourhood.

fiftb. How many perfons, per acre, does it require, and what time docs it take to dibble an acre, by any given num-bers?

Angtarr. One perfon, with a pair of dibbling inftruments, will do half an acre a day of wheat, threc quarters of an acre of barley, oats, or peas, with the afliftance of children to drop the corn into the holes; the wages, per day, of a child that drops into only une hole, is $3 \mathrm{~d}$.- - of fuch, fix are required to follow onc man; of thofe that drop into two holes, three are required to follow one man-the wages of fuch, perday, is 7d.; there are fonctimes cmployed thofe that drop into three h.u!c_thei: * wages, per day, is $10 \frac{1}{2} 1$. and only two fuch are required to fellow one nan.-Four men to divble, with their dac namber ot doppers, ale elecmed fullicient to work 11 unc part?: 
Sirth. What is the faving of feed per acre?

gnswer. Not lefs than fix pecks, nor more than eight pecks, per acre, are dibbled: if fown broadcaft, from three to four bunhels per acre.

Sebenth. What is the additional produce per acre?

angwer. This is not yet afcertained by experiment: eftimated at four to fix bufhels per acre.

CFigbth. Is the grain of a better quality?

gingter. Exceeds the broadcaft, in weight, from ten to twelve pounds in the quarter.

Nintb. Can the practice be eafily diffeminated?

andober. By employing perfons ufed to dibbling, with thofe that are totally ftrangers to the practice, will readily teach them the way: and, upon enquiry, I find perfons in this neighbourhood willing to engage themfelves, for a feafon, at a trifling addition of wages, and their travelling expences allowed them.

Iastly. Strict attention is required towards the children, that they are not fuffered to drop more than three or four grains of wheat, barley, or oats into each hole, nor more than two or three beans or peas, as it may confiderably injure the crop, befides wafte of feed.

Any information I can obtain farther, to throw light on this fubject, I Thall be happy to communicate, and remain, $\& c_{0}$ 
Answers to the Questions from the Board of Agriculture, respecting Dibbling,

By Mr.BAKER, of ACLE, DATED I3th AUGUSt, I794.

$\mathrm{T}_{\mathrm{F}}$ for information on the fubject of dibbling, I have anfwered the points referred to, in the concifeft and plaineft manner I am able.

jirot. Wheat, barley, peas, and vetches may be dibbled to advantage.

Second. The molt proper feafon (in the county of Norfolk) for dibbling wheat; is old St. Michael, and fourteen days after; for barley, the month of April ; peas and vetches, the latter end of February and March, as the fealon may be.

Thiro. The expence of dibbling, in our county, is from 8s. 6d. to 1os. per acre, for wheat and barley; and 7 s. 6d. to 8s. peas.-We have but one fort of dibbling inftruments, which have the lower end of a conical form, for making the holes.

Jourtb. The mixt and fandy foils anfwer dibbling; decp clays, I obferve, are not often dibbled, but whether it is found not to anfwer on fuch grounds, I am not able to fay.

fiftb. Two dibblers, with three droppers each, will dibble an acre per day, of twelve hours. 
sirtb. The faving of feed, per acre, is (if the droppers are carefully attended to*) about fix pecks of wheat, eight of barley, and four of peas and vetches.

Seventb. The additional produce, per acre, in wheat, I cannot fo clearly fpeak to; although I have dibbled my wheat for feveral years, I never fairly tried the experiment. Laft year was my firft dibbling of barley, and to try the difference between fowing and fetting, I dibbled a part, and fowed a part of a ten acre piece, afcertaining the quantity of each, the land hutbanded in the fame manner, and the dibbled and the fown done at the fame time; the dibbled land produced twelve buthels, per acre, more than the fown, which have induced me to dibble the whole of my barley this year.

CFingib. The grain, both of wheat and barley, that is dibbled, is of better quslity than the fown, it bcing more free from drofs, and the kernel larger.

Ninth. Dibbling has fpread very fat in our county, the diffemination thereof became eafy from the utility; fome few have introduced the drill, but the progrefs of that fytem feems to be very flow.

Lastle. The advantages in dibbling, which frike me, are as follows: the increafe of crops, the faving of feed, and the employment of a number of poor childien, which, without that, would be idle, are advantages, in my humble opinion, to be recominended.

* On the droppers depend very materially the faving of feed. I have found, as the practice of dibbling increased, that from the number of children working together, rendered it imporible to make them do their work properly; therefore, I have, thefe two or three latt years, divided my dibblers, and have not more than two work together, by which I lave the feed dropped with more propriety, and not hilf the trouble to myfelf. 
The above account, Sir, to the Board, is my own oninion, if it will be of any ufe fhall be cxtremely glad, and flall be always ready to communicate to the Board any thing I ain able.

\section{Remarks on the adrantage of Dibbling,}

\section{BY MR. WAGSTAFE.}

II

MUST be s to diffent from Mr. Kent, in refpect to dibbling being not in fo high eftimation, as fome years fince; it is, I belicve, true, that in certain dinticts of Norfolk, that, properly fpeaking, dibbling is fomewhat leffened in i's manual practice-as, to fave the expence by hand, many farmers have adopted fpiked and drill rollers, imitative of the procefs purfued in real dibbling; while this is a confeftion to, and confirmation of the utility of dibbling, its manual practice, where hands are eafily procured, doth not appear to be leffened, where it hath been long adopted, while it is annually diffufing in an adjoining county, and is become a fubject of experiment in other countics. Indeed, what this gentleman has faid, that wheat fo planted is better bodied, and confequently leavier, is true, in fact, while a faving of fecd is acknowledged: thefe, with the clover or grafty lcy's, being pafturable to the hour of ploughing, while the inverted turf is a certain manure, and forms, as it were, a matrix for the nourinhment of the einuryo fecl, which, to admiration, dilutes its fhoots, covers its allotted fpace, and each fhoot has its rulm or ftem, the car of which is more replete in number, and with a larger grain than arifes in the broaden procels: and it may be remarked, that where certain holes liave carclefsle heen 
paffed without feeding, the parallel rows, on each fide, have tillered forth their branches, whereby there hath not been an apparent deficiency, nor, perhaps, much of a real one: ccrtainly it is, in general, or with rarely an exception, that lands of the foregoing defcription, thus dibbled, with a faving, at leat, of a bufhel of feed per acre, are productive of more than the quantity faved, and that grain fpecifically weightier than from equal land, after repeated ploughings, when fown broadcaft produces.

I wifh to add, with a degree of pleafurc-a pleafure refulting from the parochial poor being found neceffary to be employed, as fome of thofe farmers who had fubftituted the fpike or drill roller, have, from a conviktion of an infetiority of the planting by hand, turned back again to dibbling and dropping; while it is a juftice, due to fome of thofe who have thus, fubftituted the roller, that they have pleaded an expediency from not being able, at all times, to procure a competent number for dibbling, \&c.-I with further to remark, perhaps, with a degree of partiality, from lhaving had the earlieft predilection for dibbling of wheat, and being the firft who called the attention of the farmers of this county to its utility, that many hundred quarters of wheat are hereby added to the national ftock, while, I believe, that little more than half the fum of its value goes to the fupport and relief of thoufands of parochial poor, who would, more generally, be deftitute of la. bour, at the period of committing the feed wheat to the ground. 


\section{On the Advantage of Dibbling Wheat.}

ExTrACTOE A LETTER FROM Mr. CHARLES VARLO, TO LORD VISCOUNT CREMORNE, DATED LONDON, Zift.JUNE, 17.94.

II Board of Agriculture, of which you are a member, one of the moft valuable improvements that, perhaps, ever appcarcd in that fcience, viz.

The method of fetting corn, grain by grain, as at prefent practiced by a great number of farmers in Norfolk, and which would become genera! in the three kingdoms, were it publicly known to be of the utility it really is.

As I was the firt that proved its value, both by theory and practice, it gives meigreat pleafure to fee the method anfiver my molt fanguine expectations, and overcome the prejudices that were firlt raifed againft it. I make no doubt, but were this method to become general, that one-third more corr would be produced, than is by the prefent mode'of random fowing, befides other advantages that would actue both to the farmer and labouring poor.

This is no chimerical fcleme, but real fatts, which I fhall literally and fimply flow as they happened :-viz.

In 1,64 I tried the experiment, and inferted the refule in my Yor!hire-fartner, pub!ined in the fecond gear, and have

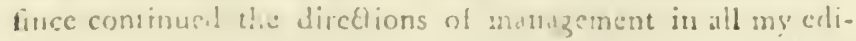


tions, both of the Ncw Sy,fem of IIufbandry, and Effence of Agriculture, which were circulated in England, Ireland, and America.

In confidering the works of nature, through all the vegetable creation, and comparing thern with the farmer's practice of fowing, I found many defects in the latter, which crampt the former from producing her abundance, but in nothing more than in that of feeding the ground, as, in moft cafes, three-fourths of the feed is thrown away by the prefent mode of randoin fowing.

Mr. Tull, and many other authors, had the fame idea, which induced them to invent drill-ploughs, in order to reduce it to fome fort of a regular fyttem by dtilling-but, by all their efforts, it never could be made general.

When I carne to confider the whole procefs, I found that even dibbling was only half doing the bufinefs, as air and roots, which keep the crop in health and vigour, can only circulate two ways; I therefore caufed a machine to be made, to place the corn regularly in a diagonal form, it was finifhed in 1764 , for which the Honourable Dublin Society voted me a premium.

With this machine I proved the proper diftances that the srain thould ftand from each other, in order to give nature liberty to produce her full increafe, but in thefe I found there is no general rule without an exception, but that circumfances muft vary decording to the foil, which, if of a deep and rich quality, and kept clear from weeds, one grain, fet in the middle of a circular foot diameter, will ftool to fill the fpace-but if the foil be of a weak, fandy, or gravelly nature, a grain would oniy fill about fix inches dianeter; however, this is fuppoling every grain to happen nothing, but to eome to maturity, which is too great a hazard to truft to ; therefore, 
experience has taught two, three, or even four grains in a hole are neceffary, and may be productive of a fure crop.

When a grain of corn vegetates, it appears with two blades fticking together, till about three inches high, then it parts and falls flat on the ground, to each fide of the root; at that period, it is what we call weaned from the kernel, and then begins to take its nutriment from the earth, whereas, the firft two blades are, in fact, no more than the kernel or flower of the feed, turned into a green.leaf; when this fprings up, it leaves in the ground the hufk or bran, which may be faid to refemble a blown egg, and thefe will remain, undecayed, even till after the corn is reaped. By thus obferving minute. ly the progrefs of the plant, through all its tages, led me to find out the caufe and preventative of fmutty wheat, a malady well known among the farmers to be the deftruction of many a good crop; having hit upon the caufe, it was eafy to find out an cffectual cure, which I have donc, is well known to numbers that have read my works, and, I belicve, I may fay, I was the firft author that fo minutely and fo largely treated on the fubject, through all its ftages of growth, from the feed to the ficklc-but to return to the fetting: the feed plant which rprings from the kernel, generally produces the ftouteft ftraw, largeftear, and boldeft grain, though, indeed, all the fisceeding thoots, which fpring from the fides, may be good, yet, in general, they are not, but abate fomething of the fize of the ear and number of the grain of the firft noot.

Nature is very prolific, and will not fail of filling the ground, fo long as the can find food to fecd the plants. The ear in the middle, which fills the kernel, will be the largeft, and, if good land, perhaps, contain from 90 to 100 grains; the next ears may abate fomething of the number, and fo on till they become very finall, perhaps, only a few grains in an ear; but, were any of thefe branches flipt off while young and tranfplanted, they would ftrike root and produce

$\mathrm{D} d$

cars 
ears of a full fize, according to the room given for the roo? to fpread; this fhews the true policy of putting a proper number of grains into each hole, two, three, or, at moft, four, is very fufficient to produce a full crop-more would ftarve the caufe, by eating one another out; four dropped in a hole of an inch diameter, (which is generally the fize of a fettingfick) would have an outfide to give them liberty to feed round, and the ear, being the produce of the flower, as before obferved, would be frong, and the itraw ftout to fupport it, whereas, fhould five, fix, feven, or more, be dropped in the fame hole, (and which is too often the cafe) they would draw each other up to be weak and dwindling, the infide plants would fuffer both for the want of food and air.

I have feen fo many cxperiments of the fort tried, that I am confident none can equal the method of fetting corn at a proper diftance, as before defcribed, in order to produce a full crop.

Another great benefit that arifes from the corn being fet at an equal diftance from each other is, that it can be quickly hoed, an operation very neceffary to kill the weeds, lighten the ground, and give vigour to the plants, and is a bufinefs that may be performed by women. boys, or girls, as the fpace between root and root is not to feck, being at a $1 \mathrm{cgular}$ diftance.

When my work made its appearance fuft among the Norfolk farmers, (which are fome of the beft in the kingdom) it was looked upon as a foolifh chimerical fcheme, and not likely to anfwer the purpofe, within any reafonable degree of cxpence, except it could be performed by a machine, fuch as ipike-rollers, \&c. and, indeed, though I was well convinced. of its utility, by the eye of reafon, yet I was rather doubt $f_{t} l$, that if it failed, this is the rock it would fplit upon; however, experience foon proved the reverfe. 
It is true, I found out the firft principle by my machine, as is before fpecified, but repeated trials fhewed, that no complicated machine was equal to fetting by hand.

About five years after my work circulated in Norfolk, bufinels brought me to that county, and in an open field, about three miles from Norwich, I was agreeably furprized to fee feveral companies at work, fetting wheat-this happened about twenty-five years fince: I never heard any thing more of it till the prefent year, I came to Lynn in Norfolk, where I dined at the Crown Inn witl a company of gentlemen farmers, who moltly followed that practice, and who all agreed, that it was a very valuable difcovery, both to the farmers and the poor.

Having fo good an opportunity of taking the fenfe of fo many refpectable farmers as were prefent, I begged to know the particular advantage that accrued from this mode of fetting, above all others they formerly practifed, and if they were willing I hould report it to the Honourabie Board of Agriculture, or the Royal Society, in order that if the members of the faid Board thought proper, they might infert it in the public papers, for the good of the community in general; they feverally anfwered, they had no objection how public it u'as made, for it was well worthy of being communicated. I requefted to know what the increafe miglit be by fetting, and the other advantages? To thefe queftions I was anfwered as follows:-Firft, that the produce was more, by ten or twelve bufnels an acre, than by the former method, particularly if the fet wheat is hoed. Secondly, it is lefs liable to misfortune, fucl as lodging, after heavy rains, mildews, \&ce. Thirdly, the fraw is ftouter and the grain bolder, confequently would give the beft price. Fourthly, employing fo many poor children, parith rates would be lels.

As to the quantity of wheat lhat might be fet in the feafon, i: may be judiged of by the gentlcmen, whole nanes are hereinsfecr 
inafter fpecified, given in writing by Mr. George Barber, one of the company, viz.

etrres.

John Barber, of Dunton, Norfolk, . . fet . . 200

Benjamin Barber, Woodbaftwick, Do. . - . : 140

Gcorge Barber, Stanninghall, Do. . - . 100

Thomas Brown, Thrigby, Do. . . - . 70

George Everit, Caifter, Do. . . - . 60

John Chriftmas, Billockby, Do. . . - . 100

James Burroughes, Efq. Burlingham, Do. - . 140

John Harrifon, Panxworth, Do. . . - . 130

Thomas Saul, Blofield, Do. . . . - . ${ }_{16} 6$

George Baker, Acle, Do. . . . - . 140

The laft gentleman (Mr. Baker) has alfo fet, by hand, a "large quantity of barley, which is found to anfwer the purpofe as well as wheat; fo would oats and rye, as they are grain that multiply, if they have room given to fpread.

If this method was become general, it would fave an immenfe quantity of feed, and keep the poor employed from February to May; and, as experience has proved, paft contradiction, the great utility of fetting wheat in fo extenfive a manner, might not the fcale be extended-even through the three kingdoms. 


\title{
REMARKS, by Dr. HINTON,
}

Upen the Advantages of Peat and Lime fir Manure, with a Recommendation of the Scuffer, as an iniprovement upon the Norfolk Plough, in very light parts of the County of Norfolh,

\begin{abstract}
I
$\mathrm{N}$ the weftern extremity of this hundred, the farmers, in general, complain of the want of manurc, to fertilize the arable land, in the extenfive parifhes of Hockwold, Wilton, Wecting, Feltwell, Methwold, and Northwold.-Thefe parithes are furrounded by twenty-five thoufand acres of lowlands, containing inexhaufible beds of cxcellent peat.
\end{abstract}

Mr. Kent, in his "Hints to Gentlemen of Landed Pro. perty," afferts, (I am convinced with great trutis) peat athes are onc of the nobleft manures we have for artificial grafles; yet it is very little known, and very far from being generally fought after. This is the cafe within the hundred of Grimthoe; what peat is dug, is mercly fur domentic ufe; the general fuel of the country is hag, or furface turf, pared off the fens: its component parts are the roots of herbage, common carth, which will not burn, and fome peat. The afhes from this fuel, are daily depofited in proper places, diftunt from the habitations of the poor, and carcfully quenclied with water, to prevent conflagration; hence arife linaps of this compound of dirt and peat-ath, moiftened by daily watering, and an expofurc to the air and rain, and fnow of winter; and yet 0.15 farmers, with the manure of this compound, get good turnips, and find it bencficial in their wheat cro ss.

How much more efficacious would be the aflies of fine unadulerated peat, prepared and preferved from the action of the air, 
air, and depofited in houfes crected for the purpofe, in the Berkflire manner.

Mr. Kent obferves, "thofe who iive in the neighbourhood of Newbury, are fenfible of the inetimable value of this manure.

I am not enabled, by chemical experiments, to determine that the qualities of the Norfolk afhes would be fimilar to thofe of Berkinire, but, fo far as I can judge from the external appearance of the peats and alhes of both counties, I am perfuaded the Grimhoe farmer would alfo be fenfible of the great value of this manure.

With all due deference, therefore, I fuggeft, that in the inrended improved edition of Mr. Kent's general view, \&c. mention may be made of this manure : and it may be enumerated among the natural advantages which this county porfeffes,

Lime, a manure in common ufe in the midland and northern counties, abounds in Norfolk, though it is feldom there applied to that purpofe. Various and contradiktory are the opinions which have been mentioned concerning the power and effects of it in agriculture-it has been commended as an excellent fertilizer, and condemned as a pernicious exhaufter of land: I confers, I cannot think it would have been applied by the midland and northern farmers, for half a century, if general experience had not afcertained its utility.

In the parifh where I refide, I find it univerfally condemned : Mr. I-, a capital farmer here, loft a crop of wheat by ufing it, ten years ago, and no one felt bold enough to make a fecond experiment. On inveltigating, lately, the particulars of this affair, I find Mr. F_ _ inftead of preparing his fallow for the feed, by putting on the lime at a proper time before fowing, actually dreffed the growing crop with 
hot cauftick lime, at the latter end of the month of March, and the confequence was fuch as might be expected from fuch a procefs: I had the fatisfaction to hear, from another quarter, that though the crop of that year was fpoiled, it was fuppofed, by fome people, that the land was the better for the lime for many years after.

Lime is fold, at the fale-kilns in this county, at an high price, 1 s. per chaldron-and this prefents a formidable obftacle to the general ufe of it in agriculture. Coals arc dear, and the war has advanced the price of them-but chalk lime-ftone abounds every where with us, and may be got on. eafy terms; fo that, $I$ an perfuaded, notwithftanding the pre. fent price of coal, a farmer may burn his own lime at $9^{\text {s. }} 6 \mathrm{~d}$. per chaldron: allowing even $3 \frac{T}{2}$ chaldrons of lime to an acre, the coft of manure is only 1. 12s. gd. and the charges of carting it are infinitcly lefs than thofe of carting dung fuflicient for an acre of land, as are alfo loading and fprcading.

Part of our landsare diftant from the homefteads thrce miles-the cxpence of manuring thefe lands is immenfe; three journies in a day, is the work of four ftout horfes. Thefe horfes would, in one day, draw lime fufficient to manure two acres of that land, which, if manured with dung, would require the work of four horfes (at three journey's jer day, at only ninc loads per acre) fix days.

Chalk lime-fone is fort, why may it not be calcined with peat?

The brick-makers at Cley, who fupply us here with that article for building, of a moft excellent quality, ufe peat in burning them; perhaps, the heat may be fo quick and intente, as to vitrify the lime fhone; perhaps, the alkaline falt, which the peat coniains, may promote that vitrifation. 
But, perhaps, thefe evils may not happen, or may be pre. rented by proper expedients, viz. burning the lime in an open kiln, and not in a reverberatory one, hence the draught or current of air would be very weak, and we know vitrification is the effect only of the higher degrees of heat: the fire may be made jointly of coal and peat.

If peat can be ufed in burning lime, an incorporation of peat-ahes with the lime, might improve the manure.

To convince my parifhioners, that lime is a very valuable manure, I made the fair comparative experiment bereafter mentioned:-Between two lands, manured with yard dung, I manured an intermediate one, with lime, for turnins-the ploughings and culture, as well as the quality, of the three lands wcre fimilar. The turnips have all had the firft hoeing, but fuch is the fuperiority of the crop, on the limed land, that every perfon, who hath viewed them, is convinced, that Iime, though it deftroyed wheat, would not kill turnips.-I impute the fuperiority of the turnip crop, to the novelty, if I may fo call it, of the manure.

May not fomewhat be faid in the intended publication, to remind the men of Norfolk, that abundance of lime. ftone is another of the natural advantages which this county poffeffes.

Ploughing is certainly done, as Mr. Kent obferves, with greater eafe, in this county, than any other, and much cheaper.

I conceive an improvement may be made in the culture of the light lands of the hundreds of Shropham, Guiltcrofs, Weys land, South Greenhoe, and Grimhoe, by introducing the ufe of the new Scufler, recommended by the Agricultural Society of Leicefterhire.--This inftrument is defigned for ftirring arable light lands, which have been previnufly broken up by the plough. 
I faw one of thefe fcufflers (conftructed by the ingenious Mr. Hanford, of Huthen, near Loughborough,) at work in a field, the foil a fandy loam, worth 11s. per acre; it was drawn by three horfes, of no greater ftrength or value than our Norfolk Fen-jades, and effectually firred five acres in a day.

N. B. The other remarks of Dr. IInton are taken notice of, in this revifed edition, in their proper places.

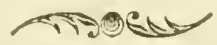

\section{A useful Hint from Mr. Wagstaff, respect- ing the raising of New Fences.}

\section{DATED NORWICI, NOVEMBER, 1794.}

I. ruggefting what I have experienced practical: viz.-That fences may be ftrengthened, while that additional ftrength máy become fubfervient to what (in fome fituations) may more than pay the rental of the land they inclofe. Crab, white and black-thorn, are generally allowed to form the moft complete fences; the firn, it is well known, may be fuccefsfully engrafted with every fpecies of apples; the fecond, though not lo well known, may be fuccefsfully, and more fruitully, engrafeed with cvery fpecies of pears; the third, effecially if the layer or quick is raifed from plumb-ftones, tecone fafeptible of every fpecies of that fruit: hence, whether either of thofe wildings be ranked together, or commixt, each lpecies, at due intervals, may lxe cnyrafted or budded with its congenial fruit; and while the ongrafted or inocu- 
lated bole rifes to a ftandard tree, their intervals may be clipt, and, in courfe, ftrengthened as a fence. It may be requifite to obferve, that no ftock receives and nourithes with more admirable facility its graft, than the white-thorn, the fcion or bud of the pear; but, in confequence of the engraftment being four or more feet from the ground, the fcion foon becomes larger in diameter than the ftock, but this circumftance I have made fubfervient to their bearing, by leading their very vigorous thoots to ftakes or ftandard trees, where affixed, they acquire the form and fruitfulnefs of an efpalier, which being raifed two or three feet above the quick, are out of the reach of the bite of cattle, and form a complete barrier againft their leaping over, or breaking through: with equal eafe they may afcend into fturdy ftandards, by being engrafted within an inch or two of the bank. It may be needlefs to add, that the firft mentioned genus of fruit trees may thus be promoted to a manufactory of cyder and perry; and from fmall farms in the vicinity of towns, or in eafy communication with the metropolis, fupply their alimental produce for immediate confumption, perhaps, in fome favourable ycars, to the amount, in value, of the other produce of fingle or two-fold acres they inclofe.

I wifh to avoid repetition, but I am perfuaded of the practicability of this fcheme of inclofure, and farther, that the wild and bird cherry (Prunus Padus) are feverally fufceptible of every fpecics of cherries: thefe various ftocks, thus ameliorated, would be beautiful in object, fubftantial in value; and be of provincial benefit wherever adopted. 


\title{
ON THE
}

\section{Uses and Value of the Spanish Chesmut.}

\author{
ZETTER RROM MR.KENT, TO THE PRESIDENT OF THE \\ SOCIETY OF ARTS, MANUFACTURES, AND COM- \\ MERCE, DATED 16th JAN. 1792.
}

\section{(1)}

SINCE I have had the honour of becoming a member of the Society for the Encouragement of Arts, Manufactures, and Commerce, I have read with great fatisfaction Mr. Majendie's judicious remarks upon the Spanifh chefnut, in the rinth volume of their Tranfactions, page 17, and obfervation and cxperience have long convinced me, that it is the moft profitable tree that can be planted. Although the character which he gives of it, has in a great meafure anticipated what I had to fay in its favour, ftill I am perfuaded a few more particulars relative to it, will not be confidered impertinent or illtimed, though it may in fome infances carry the appearance of repetition.

I cntirely agree with Mr. Majendic, that, for hop-poles and Itakes, it has no cqual, in point of durability, and confequently no underwood can be applied to thofe purpofes with equal profit. He fecms to think, indeed, that it is not fo quick in its growth as $2 \mathrm{~h}$; upon a moift foil, I think it is not, but upon a fand or loam, I apprchend it will keep full pace with the afh, and attain fufficient fize for hop-poles in fourteen years, and be worth at that age two guincas a hundred, and laft, with proper care, twcuty ycars; whilf anı, which feldom comes to fufficient fize in lefs than twenty years, will only bear two-thirds of the price, and decay in kalf the time. 
- For gates and hurdles it is equally good, and being lefs heavy than oak, is another great recommendation to it, as it is removed from one place to another with greater eafe. To thefe and many other purpofes, cheínut, trained and cut as underwood, is peculiarly adapted; and, in point of beauty, no woud furpaffes it, as it admits of clofe planting, runs ftrait in its branches, and always appears florid and healthy:

I thall next confider the value of the Spanifh chefnut for timber, in which (except for the unrivalled purpofes of fhip-building) it will be found for moft ufes equal to the oak, and in buildings and out-door work much fuperior.

In 1676 , an anceftor of the prefent $\mathrm{Mr}$. Windham, of Felbrigg, in Norfolk, had the merit of being a confiderable planter of chefnut. In the fpace of fifty years, it is prefumed thefe plantations required thinning, as his fucceffor, about that time, began to apply this timber to ufeful purpofes upon his eftate.

The firf account is of the branch or limb of a chefnut, about thirteen inches fquare, which, in the year 1726 , was put down as a hanging poft for a gate, and carried the gate, without alteration, fifty-two years, when, upon altering the inclofures of the farm where it ftood, it was taken up, under my direction, and appearing to be perfectly found, was put down for a clapping-poft in another place.

In 1743 , a large barn was built with fome of this timber, and is now as found in every part, beams, principals, and fpars, as when firft the barn was built: about the fame time, feveral chefnut polts and rails were put down, which I have fince feen removed, and after ftanding thirty or forty years, generally appeared fo found, as to admit of being fet up in fome other place. 
The laft inftance I thall mention, though not of lone date, will hew the great fuperiority of this timber over oak in fences. In the year 1772 , the prefent Mr. Windham made a large plantation in his park, which was fenced with pofts and rails, converted from young oaks and chefnuts of the fame age and fcantling, fuch as were picked out of a place where they ftood too thick. Laft year, upon Mr. Windham's enlarging his plantation, it was neceffary to remove this fencewhen the chefnut pofts were found as fonind as when they were firft put down, but the oak were fo inuch wanted, juft below the furface of the ground, that they could not be ufed for the fame purpofes again, without the aflitance of a fpur to fupport them.

To thefe modern proofs of the utility and durability, we may join the authority of Evelyn, an author of entablifhed re. putation, who afferts, it is good for "mill-timber and water"work, and that great part of our ancient houfes in the citv "6 of London werc built with it, and that it clocs swell for table c? and other furniture."

As a candid quoter of Evelyn, however, I admit that he fays, in another piace. that he "cannot celebratc this trce for "its fincerity", it being found (contrary to oak) it will make a "fair fhow outwardly, when it is all decaved and rotten "within; but that this is in fome fort recompenfed, for the "beams have the pronerty of being fomewhat brittle, of " crackling, and giving warning of danger,"

To account for this drawlyack in Mr. Fevelyn's opinion, it will be proper to obferve, that this certainly is the cafe with old chefnut, that has heen fuffered to fand beyond the time of its attaining its full growth; it is then the work of all timber, being more brittle and mure apt tocrack, and fly intes fplinters than any other: but I have never known this to bo the cafe with yound chefnut, and therefore in point of ecere 
nomy, it Thould never be fuffered to ftand longer than the points of the branches, and the complexion of the bark, indicate it to be in a growing or healthy ftate, which is not very difficult to afecrtain, by a perfon accuftomed to make obfervations upon timber; and it is this very circumftance, when properly attended to, that makes this timber more profitable than molt others; for it is fo early ufeful, that if it be cut when it fquares only fix inches, it will be as durable as an oak of fix times its fize and age. This is in a great meafure accounted for, by its having fo little fap in proportion to other trees, as it will feldom exceed in thicknefs the breadth of the bark; whereas the fap of an oak will often be from an inch to two inches thick, which is not only ufelefs, but if fufered to remain, tends very much to the deftruction of the timber: in other refpects, the duration of the chefnut may be accounted for, from its being lefs affected by worms or infects than other timber; otherwife it would be impofible that fuch roofs as King's college, Cambridge, built in the reign of Henry VI. with chefnut, and many other equally ancient buildings, fhould have lafted fo long, and be ftill in fuch a perfect ftate as many of them are.

Therefore, like Mr. Majendie, I earneftly with to fee the culture of this moft valuable plant, extended over every part of the kingdom, as it muft prove highly beneficial to the public.

But let no one be afraid of cutting it too young; for, let this tree be ever fo fmall, if it is large enough for the purpofe for which it is wanted, it will be the lefs liable to decay from its youth; and, if underwood be the objes, the proverb, in beech countries, will be fully verified, "Cut wood and have "rood."? 
Substance of the Contracts athich subsist bctïeen Thomas William Coke, Esq. and his Tenants.

\title{
Cbe Iamolord,
}

\begin{abstract}
A
FTER a proper defcription of the parcels, demifes, for the term of twenty-one years, at a fair fipulated rent, which is referved to be paid half-yearly, out of which land-tax is deducled-all other refervations and reftrictions are containcd under the
\end{abstract}

\section{TENAJT'S OBIIGATION;}

Which are as follow:-That he will not affign, transfer, fet over, or part his intereft in the eftate, to any perfon, except to his wife, child or children, without the licence of his landard, firft obtained in writing, under penalty of forfeiting his remaining term.- He will not lop, top, or prune any maiden tree, or cut down any young fapling, like to become timber, under penalty of paying three times the value of fuch timbertree or rapling fo lopped, topped, pruned, or cut ciown.That he will not break up or convert into arable, any old meadow or pafture land, without licence fo to do, under penalty of five pounds an acre additional yearly rent, to be paid from the time of fuch breaking up to the end of the term : and double that penalty for the laft year.-That he will, during the whole of the term, endeavour as much as polfible to adhere and conform to the courfe of cropping all his arable land, under fix hifes, or cqual portions, of whicls one fhift thall be in turnips, or vetches fed off with nuep; wo other Mifts in grafs fecds ("Which fhall wot be truken ut) tilt 
the fame have lain two years); one other fhift in wheat, and the remaining two thifts with lent grain.-But in cafe it thall fo happen that the grafs feeds fhall at any time fail, fo as to render it teafonable to break up any particular piece of land, after it hias been in grafs only one year, then he thall be permitted to break up fuch piece of land after one year's lay, taking only one crop of corn or grain after fuch one year's lay, and then fummer tilling the fame for turnips, and fo bringing it round again as foon as polible under the regular courle of fix thifts beforc Atipulated. - That he will in the laft year of the term leave one full fixth part of all the arable land hereby demifed in grafs fecds of one year's lay; one other fixth part in two vear's lay; one other fixth part in turnips, fown upon a fourth earth, well mucked and twice hoed.-That he will expend and confume all his hay, ftraw, and ftover, upon fome part of the premifes curing the whole of the term, and lay and fpread all ine muck, dung, and compolt arifing therefiom upon fuch parts of the land as is moft proper to beftow the fame upon.-And that he will imbarn and ftack all his laft year's crop of corn or hay upon the premifes in the laft year of the term, and leave the dung arifing from the laf crop but one properly turned up in heaps, in the yards or fome otler fuitable part of the premifes, on or before Nidfummer day in the latt year of the term. - That he will keep all his hedges, ditches, mounds, and fences in good order and condition during the whole of the term; and new make or repair one-twelfth part of the whole every year; and at the time of fuch making or repairing the fame, will lop fuch pollards as have been ufually lopped clofe to their heads, and cut down all the buthes, thorns, and ftemwood, clofe to the ftools on which they grow, and effectually fcour and cleanfe the ditches belonging to the fame, and alfo permit and fuffer any trees to be planted in or near the fame which the faid Thomas William Coke may think proper to plant, and do all in his power to protect the fame.-That he will carry all materials for repairs, pay all carpenters', 
carpenters', bricklayers', and other artificers' wages, find al. lowance beer, nails and gate-irons, fraw for thatching and clay for daubing, and likewife keep gates, ftiles, rails, locks, bars, and bolts. in good repair, being allowed timber in the rough, bricks, tiles, lime, and hair, for doing the fame.-That he will at any time during the term hereby demifed agree and fubmit to any exchange of land that may be propofed, having other larid of equal quantity or value laid to him in lieu of what he may be required to give up.-That he will permit and fuffer the fucceding tenant to fow any grafs feeds he may choole upon fuch pare of his land as he may fow with lent grain in the laft year of the term, and that he will fufficiently harrow in the fame gratis.

LASTLY it is agreed, for the mutual convenience of both parties, that the hay and turnips which Ihall be left upon the premifes at the expiration of the term, fhall then be valued by two impartial perfons competent to value the fame; and if they cannot agree in fuch valuation, they fhall have power to call in and appoint any third perfon they may choofe as an umpire, to Rettle the difference between them; and the value fo fettled thall be paid by the in-coming to the outgoing tenant. - That the out-going tenant thall be fuffered to retain the ufe of the barns and ftack yard till the firft of May next after the expiration of the term, for the purpofe of fuperintending the threfhing out and dreffing his laft year's crop of corn - That the in coming tenant hall have liberty to enter upon the yards, part of the Itables, and upon the fixth part of arable land, being the fecond year's lay, at Midfummer previous to the expiration of the term, for the purpofe of carrying out the inuck and making the fummer fallows for an enfuing wheat cron. - That the in-coming tenant thall be entitled to the ftraw; chaft, and colder, arifing from the lan year's crop of corn; but thall be at the expence of threlling out the faid conn, and carrying it to the ufual markets, for and in lizu of the faid ftraw, chaff. and colder. 


\section{FATTING SCOTCH CATTLE.}

A comparative Statement of the Procefs, Expence and Profit attending three different Kinds of Scotch Cattle, grazed in Norfolk, particularly the Galloway Scot, for which I ams indebted to Mr. Burton, of Hempnall.

D

F the Scotch cattle, there are three forts which require confideration. The firft is a bullock bought at St. Faith's fo: about gl. turned of four years old, in fuch condition as is fit to be put immediately to turnips-this bullock is fuppofed to be brought to from fifty to fifty-two ftone. He is put to turnips for about twenty-four weeks, the average expence of which, including turnips, carriage and attendance, and in cafe of bad weather, when a little hay is ufually given, befides the ftraw, cannot be reckoned lefs than $4^{\text {s. per week, }}$ this brings him to ${ }_{1} 3 \mathrm{l}, 16 \mathrm{~s}$. and fuch a bullock generally will fetch about $5 \mathrm{~s} .6 \mathrm{~d}$. per ftone of 14 lbs. which amounts to s! $16 \mathrm{~s}$.

The fecond bullock is bought quite lean, about the fame time as the former, for about 61 . and is a year younger than the former. He is firft put into ftubble or ordinary grafs till the ftraw yard is open, and then he is put to ftraw at night, and eats the offal turnips after the better beaft in the daytime-his keep in this way, twenty-four weeks, till May-day, may be fet at 1s. $6 \mathrm{~d}$. per week; he fhould then be put to marfis or into good pafture till a fortnight after Michaelmas, which, fay twenty-eight weeks, at $2 \mathrm{~s} .3 \mathrm{~d}$. per week, is 3 l. $3 \mathrm{~s}$. ; he then gocs to turnips, like the former bullock, for cight weeks, at 3 s. which is $11.4 \mathrm{~s}$; his aggregate charge is then 121. 35. - his weight may be expeeted to be forty-four ftone, and value i2!. 25 ,

The 
The third, fuppofed to be bought at Harlefton in Decem. ber, a lean beaft of the fame age as the firft, price 7 . He goes immediately to ftraw and offal turnips for about eight weeks, at Is. 6d. which is $12 \mathrm{~s}$. ; then he goes to full keeping at turnips by day, and lies in the ftraw yards at night, about ten weeks, at $2 \mathrm{~s} .6 \mathrm{~d}$. which is $1 \mathrm{l} .5 \mathrm{~s} . ;$ he is then put into the fecond year's lay or good pafture till harvent, about twenty

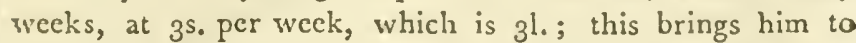
11. 17s. - he will then generally be about forty-fix ftone, at 5 s. $6 \mathrm{~d}$. which will amount to 121.13 s.

The fair deduction to be made from this ftatement is, that the firft pays 10 per cent. intereft upon the capital laid out, and allo a fair price for every thing he confumes.

The fecond returns no intereft for the original coft, but pays a fair price for what he confumes.

The third pays 15 per cent. for the original fum laid out, befides paying like the reft for what he confumes.

It fhould feem at firft view of this ftatement, that there is fo little profit attending this fyftem of grazing, that it is not a procels to be recommended; but if we confider the advantage which the fucceeding crops owe to it, in confequence of the great quantity of manure, to fay nothing of the advantage of treading, which on a light foil is a vaft thing, we thall be fatisfied of the great advantage derived from it.

It may not be amifs to obferve, however, that it is obvious that the reafon why the fecond does not pay in fo large a proportion as the other, is owing to his being longer in land, 



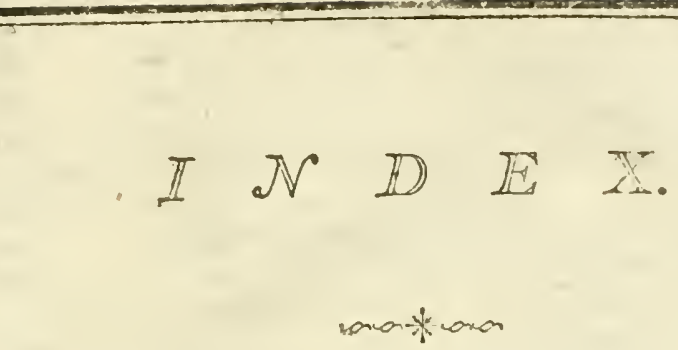

$\operatorname{IsC} 2$

A griculture, its diffufive and fuperior advantages,

Its profperity connected in three $\mathrm{ma-}$ tural ties,

BOARD OF AGRICULTURE, its firft apparent object,

The good effects to be expected

from it, with a lint to its

Members, - 5

The Norf ilk hubandry particu-

larly deferving its attentiun, I5I

BARLEY, how many tilths fown upon, - 45

Its great aid to the revenue, - $\quad-\quad 150$

BUCK WHEAT, the beft mode of introducing it, - 62 Beans, but little cultivated, - - ibid. BURN-BAKING, its pernicious and deftruEtive cffets, $1 \$_{3}$ to 18 y A temporary incrafe of rent no decifive proof of advantage from it, $\quad-\quad 18$ ? Old fward effential to the health of a llock, ibid.

CONients, and divifion, - - 6 and?

CLIMATE, and weather, - - $\quad$ so

Composts, the Effex method of turning up banks and bor-

ders recommended, - $\quad 2.7$

COPYHOLD, different kinds of it, - 28

Cropplic, the fix and ine courfe thifis, - 33

The four courfe fhift fimilas to Flanders, 33

Hints for an occafional improvement upon the differest thift; $\quad$ - $\quad$ - $33 \mathrm{axt}$ it Ocrafional varigtion thouid be allowich, is 
CLOVER, Cufrom of mowing and grazing it, 45

CROPS, their fuppofed average, $\cdots \quad-\cdots \quad \cdots \quad{ }^{6}$

CABBAGE, worth attention, - - $\quad 62$

Carrots, of great value, - - ibid.

COMMON FIELDS, Lord Chief Juftice Coke's idea of their origin, - - $\quad-\quad 72$

Difadvantages attending them, $\quad 73$

Conmons, their different quality

Lamentable that they fhould remain in their prefent ftate, -

ibid. Arguments for their continuance fallacious, ibid. Their fuppofed quantity, - $\quad 82$ Lofs futtained by the public, - $\quad$ ibid. Cows, the Suffolk fort beft for the farmer, _. $\quad .100$ The old fort bent for the cottager, - - ibid.

Crossing, fome afinity ought always to be obferved, 104 Should always be done with caution, 108

COTTAGEs, a wifh to fee them of a comfortable fort, I1s CONSUMPTION, how different in quantity between the horfe and the human mouth, - $\quad 141$

COMMERCE, the credit of Norfolk itands high, $\quad 143$ to 150

Its great export of corn, fat bullocks and fheep, \&c. fent to London, 144 to 149

DIввLING, great benefit refulting from it, - 38

DRAINING, a good method upon meadows, - 50

'The Eflex method beft upon arable land, 5 I

DEcoys, not fo numerous as they might be, - 306

EsTATEs, one of the advantages refulting from large oneş 57

Frost, a great fertilizer of land, - $\quad$ - 19

FOLDING SHEEP, permanent folds make great quantity of ufeful manure, $\quad$ - $\quad 2 \ddot{5}$

A good practice folding upon fown corn, 34

FlAX AND HEMP, - - -

FARMERs, the worft clafs of landlords, - 57

A duty incumbent on them, $\quad 172$ and 173

Recommended to confider the labourer of real importance, - $\quad$ - 193

Fallowsac exploded, - $\quad-\quad 66$ 
Farms, the mort profitable fize confidered, Arguments in favour of each,

The arguments weighed,

Their different ettects upon fociety,

Excefs to be avoided in lize,

FaIRs, a lift of them,

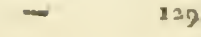

- 130

30 in $13 x$

133 to 133

$13+$ and $13 ;$

166 and 167

FISHERIES, profit of the herring fifhery, -

Might be improved by checking the Dusch, $\quad 1$ fig

FENCES, raifed well and managed ill,

IS 2 and 133

GAME, abundant but too often the fource of aninofity,

107

GREAT WORK, recommendal as much as polfible,

GRASS SEEDS, thould be chofen agreeably to foil,

Grizing and Ploughing, will always correct the execis of

$\begin{array}{rr}\text { each other, } & \text { it } \\ \text { Common profits on grazing, } & 102\end{array}$

Arerage weiglst of a Scotch bul-

lock,

ibid.

Average weight of a llome-bred, 102

HERRroTs, but little known in this county,

HEMP avd FLAX, their national importance,

Hops, very little cultivated,

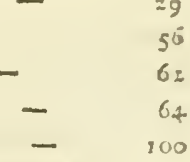

HIAY, a more frugal ufe of it recommended, - -
HorSEs, defcribed,

HERMAPHRUDITES, ufeful on finall farms and in bufy fenfons, in

Harvesting, the general mode in Nortolk reprehenfible,

180 and is:

IRRIGATION, recommended when practicable,

INCLOSURES, their advantage, and favourable to population, 5 I to 6 ;

73 and 74 $\left.\begin{array}{l}\text { Obftruetions thould be removed, } \\ \text { Highly deferving encouragement from } \\ \text { the legiflature, }\end{array}\right\}$ i 6 and 77

Would be good policy in government,

IIME, a ufeful hint for its ure by Dr. Hinton,

LEASEHOLDS, very fcw on lives, thourh for cottages this tcnure is recommended

LUCERS, a great help,

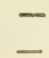

I.AND, recommended to be improved hefore Pock, as thic im-

provenent of the latter will maturally follow, 
LEASES, they are the firf and greateft of all encouragemerit, 123

Rents greaily improved by means of them, ibid.

Ziberal covenants recommended, - $\quad 124$

Strons prejudices againft them, - ibid.

A land-owner owes fomething to fociety, $\quad 125$

Unreafonable to expect improvement without them, 126

MARL, its excellent qualities,

A hint for the fecond time of ufing it, - $\quad 23$

MEADCws, much neglected, - - 50

An eaty way to improve them, - $5^{\text {I }}$

Aistries, defcribed, - - - $\quad 52$

MANufacturas, deferve feparate inveftigation; 146

MARKErs, the decline of them againft the labourer and artificer, $\quad-\quad-\quad-\quad-167$

Navigation, its great advantages, $\quad-\quad 17$ and 18 An important hint upon this fuiject from $\mathrm{Mr}$.

Colhoun,

ORCIIARDS, very few, and thofe ill-managed, - 63

OXEN, but little ufed for labour, - - 108

Great arlvantage in working them, - $\quad 138$

Proportions of thofe fitted, - 101

Their credit fully eftablifhed by Lord Hawke; 139

Good rules for managing them, I39 and 140

POPULATron, of the great towns,

Of the whoie county, - - -

The molt ufeful fort, - $\quad$ - 57

Increafed by inclofures, - $\quad 74$

Its proportion to quantity of land, 82

Injured by little fams being fet afide, $\quad 133$

Prospects, not extenfive, - 12

PEAT, advantages of it pointed out by Dr. Hinton, 26

Ploughisc, the great eafe with which it is done in this

county, $\quad$ - $\quad$ - $\quad{ }_{3}^{6}$

Practice of two journies a day recommended, ibid.

The general method worth imitation in many other parts of England, $\quad-\quad 1 \quad 37$

Advantages of fhallow ploughing, in point of keeping land clean and requiring a lefs quan-

tity of ın:nure, - $\quad$ - ibid.

Parks, 
PARKs, a hint for their improvement,

Potatoes, cannot be too extenfively cultivated,

Great encouragement from Mr. Marham's and Lord Walpole's fuccệs, 87 and 94

Expcriment to facilitate the growth of trees, 88

The Flemifl method defcribed, ibid.

The larch illuftrated by the ufes Mr. Berney lias put it to, - $\quad$ - $\quad 89$

Beft time of cutting the larch, $\quad 9^{\circ}$

Great extent of Mr. Coke's plantations, ibid.

His cultom relative to the poor highly deferving imitation,

ibial.

The aftonifling thrift of Mr. Windhan's from feed,

Are a great comfort to cattle, $\quad 92$

Improve and add to the foil, - $\quad 23$

Thofe of Sir Wm. Jerninghan's made with great tafte, - $\quad$ - ibis.

Proof that they may be raifed in defiance of the fea haze, - $\quad$ - $\quad 94$

Recommended to be made in a great body, $\quad 97$ A method fometimes proper in parks, ibid.

PINASTER, an inftance of its quick growth, - 95 PRUAing TREEs, an infamous practice, - 97 PIGs, not handfome but prolific, - $\quad 106$ POULtRY, fuperlatively good, the turkies unrivalled ibid. Pigeons, diminifled and for what caufe, POLlards, ufeful in repairs, - - $\quad 114$ Plough5, well calculated for light lands, - 118 Provisions, dearnefs of, fuppofed to proceed in fome meafure from the dropping of public markets,

From no: uf:ng more oxen and lefs horfes, and the great increafe of horfes of luxury, $\quad 142$ General price of thein, 168 and 169

Pook Rates, formerly fo light as to be no objest to the

$\begin{array}{ll}\text { famer, } & \text { 153 } \\ \text { The clicf caufe of their increafe, } & \text { 196 }\end{array}$
Houfes cf Indultry not equal to the gricvance, ibid. Grievous in the ey es of the prour, 
POOR RATEs, a principal reafon why they are fo high in local fituations,

Commons rather increafe than leffen the rates, 158

Poor, principles to be kept alive in their minds, 170

A man worn out by labour lias a juft claim for relief on

fociety,<smiles>[CH]</smiles>

I7t

Social' clibs deferve encouragement, - $\quad$ ibid.

Earl Harcourt's example highly deferving imitation, $\quad 172$

Comfortable cottages a great encouragement,

173

Propriety of taxing the labour of the young to aid the old and decrépid;

Prejudice, mult be laid afide, or I fhall have written and the reader will read in vain,

REPAIRs, an error to bilild too extenfively,

Average expence,

The ufual materials,

The wet country inode of thatching ftrongly re-

commended,

ibid.

Effential to fix upon a proper fpot for building,

A practice eftablined by me upon Mr. Anfon's and

Sir Philip Stephens's eftates,

KONDS, fuperior to moftother counties,

Compliment upon them by Charles $\Pi$.

ibid.

RIVER WEEDS, an excellent manure for turnips;

RENT, has no fixed fcale, - - $\quad 57$

Its neareft average, - $\quad 5^{8}$

Restinc LAND, its fuppofed origin, - 66

A ridiculous cuftom, $\quad-\quad 67$

ROLLERS, the drill-roller defcribed, - - II?

An inprovement upon broad-caft, but inferior to dibbling,

A new inftrument defcribed,

REPREHENSIBLE PRACTICE, of the poor curting up commons,

RABBiss; very numerous, and in warréns very profitable, but in plantations a great nuifance, 
SURFACE, in general flat, - $\quad-12$ Soll, chiefly fand, -

In fome parts, however, mixed with clayey particles, Is

In another part ooze, - $\quad$ - IA

SEA-SAND, how ufed for manure, - -

SHEEP, the agile conftruction of a Norfolk theep peculiarly adapted to the foil, - $\quad 102$

The Leicefterhire fort not calculated for the fold, 103

But anfwer in parks and fmall inclofures, 104

General profit upon them, - _ $\quad 105$

SrACKING, ought to be more general, : - IIt

SPANISH CHESNUT, the beft-timber for building, II

STRAW, thould be found by tenants, -

SEEDING, general practices refpecting it, $\quad 38$ and 39

SIVAMPY LAND, great lors fuftained by neglecting it, 53

SAINT ForN, foil beft adapted to it, - st and $6_{3}$

Great quantity planted by Mr. Coke, $\quad 63$

TEMPESTS, not lafting, - - - II

TENURES, fuppofed proportion in freelold, copyhold, and church lands, - $\quad$ - $\quad 29$

Advantages of inferior tenures, $\quad 30$ and $3 \mathbf{I}$

TURNirs, excellence of their hurbandry, - 39

To whom the country is indebted for their or'g1nal introduction,

Average quantity of a good crop, ibıd. Advantages on the aggregate almoft ineftimable, ihid. Rules worth obferving in their culture, $4 \mathrm{~s}$ Particular manures ufed in raifing them by $\mathrm{Mr}$. Styleman, Mr. Coke, and Mr. Branthwaite, 4 I \& 42 A lint to keep off too quick a fucceflion, $\quad 43$ Iloeing an effential part of their culture, ibid. Cautions againft the fly, $\quad$ - 44 Different mode of feeding cattle with them, 44 to 48 TU:Aerils, fhould be in more gencral ufe, - 188 TrTues, impartially conficlered, - $\quad$ - 153

The clergy do not let them higher ir general than lay-impropriators, - $\quad$ - $\quad 154$

Seldom taken in kind, - $\quad 155$ Yet they are difcouraging to arriculture, ibicl.

Excinption too fisort upon fiefli cultivated lind, ibisl. Difficult to fettle an equivilent for them, iisl. 
TRUE JUDGMENT, in what it confifts,

VETCHBS, ftrongly recommended,

Visionary SCHEMEs fhould not be followed,

WHEAT, when fown upon one year's lay has only one plough-

$$
\text { ing, }
$$

The old practice when fown on two year's' lay, $38 \& 39$

WOODs, not very extenfive,

Ufes to which the underwood is applied, ibid.

WAGgons, the Norfolk waggon too heavy, - II8

The Berkfhire waggon recommended, 119

WAGES, yearly and daily,

159

For different kinds of hubandry, 160 to 163 


\section{$E R R A T A$.}

In p. 162, 1.6, for "seventy" read seven.

p. 164 , 1. 1, for " $18 \mathrm{~d}$. per bead" read $18 \mathrm{~d}$. each person per zueek. p. 207 , 1. 19, for "acrue" read accrue.

\section{Directions to the Linder.}

Sketch of the County, . . . . . . 10 front the title. The Norfolk Plough, . . . . . . 10 face $p .{ }^{6}$

Norfolk Ram, . . . . . . . . . p. 106

Norfolk Hermaphrodite, and Berknire Waggon, . . p. 119 
